\title{
Taking Future Claims Seriously: Future Claims and Successor Liability in Bankruptcy
}

Frederick Tung

Follow this and additional works at: https://scholarlycommons.law.case.edu/caselrev

Part of the Law Commons

\section{Recommended Citation}

Frederick Tung, Taking Future Claims Seriously: Future Claims and Successor Liability in Bankruptcy, 49 Case W. Rsrv. L. Rev. 435 (1999)

Available at: https://scholarlycommons.law.case.edu/caselrev/vol49/iss3/3

This Article is brought to you for free and open access by the Student Journals at Case Western Reserve University School of Law Scholarly Commons. It has been accepted for inclusion in Case Western Reserve Law Review by an authorized administrator of Case Western Reserve University School of Law Scholarly Commons. 


\title{
ARTICLES
}

\section{TAKING FUtURE Claims SERIOUSLY: FUTURE ClaIMS AND SUCCESSOR LIABILITY IN BANKRUPTCY}

\author{
Frederick Tung ${ }^{\dagger}$
}

I. INTRODUCTION 438

II. BACKGROUND ….....................................................................443

A. Form and Substance in the Sale of a Business ....................443

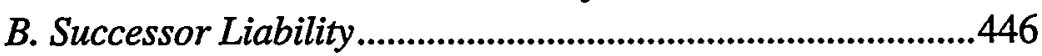

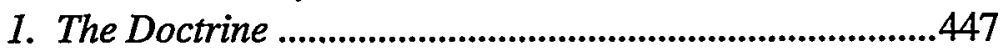

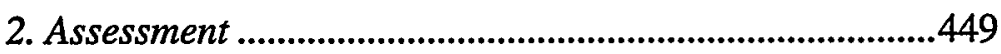

C. Bankruptcy Reorganization and Bankruptcy Sales .............450

1. Reorganization and the Common Pool ............................451

2. Future Claims and the Common Pool..............................453

3. The Bankruptcy Sale ....................................................453

III. FUTURE ClAIMS IN REORGANIZATION...................................455

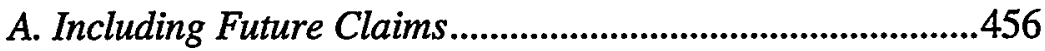

\footnotetext{
${ }^{\dagger}$ Associate Professor of Law, University of San Francisco School of Law. A.B. 1983, Cornell University; J.D. 1987, Harvard University. Many thanks to David Epstein, Susan Freiwald, Michael Green, Kate Heidt, and Steven Shatz for thoughtful conversation and invaluable comments on earlier drafts of this Article. Special thanks to Lynn LoPucki for his always insightful and careful critique. This Article also benefited greatly from comments from my colleagues participating in a faculty workshop at the University of San Francisco School of Law. Any errors or omissions were committed against their better advice and remain my responsibility alone. Research for this Article was supported by a grant from the University of San Francisco School of Law.
} 
B. Mandatory Inclusion Versus Flexibility ..............................459

C. Current Practice: Costs Versus Conceptual Clarity...........461

1. The "Traditional" Approach in the Mass Tort Context..462

2. Pragmatism with Future Claims 465

a. "Creditors" and "Claims": The Statutory Issue..........466

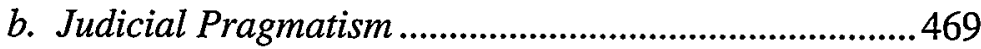

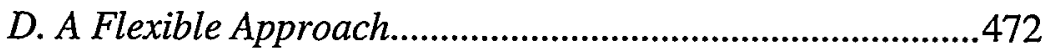

1. The Flexible Approach in External Reorganization ........472

2. Current Creditors' Calculus .............................................473

a. Asset Disposition Alternatives........................................4 474

b. Future Claimants' Predicament.......................................47

3. Some Observations Concerning Transaction Costs........479

4. A Note on Equal Treatment .............................................482

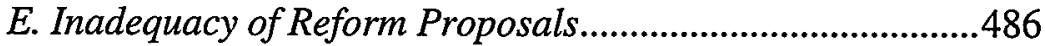

IV. SUCCESSOR LIABILITY AND EXTERNAL REORGANIZATION....486

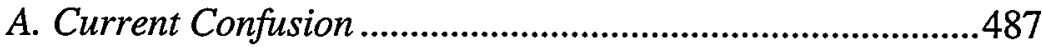

B. Chapter 11 Discharge and the Channeling Injunction........492

1. Functional Parallels.........................................................492

2. The Channeling Injunction and Bankruptcy Norms.........493

C. Future Claimants' Position ..............................................495

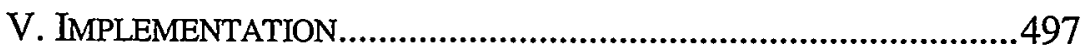

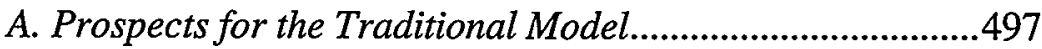

B. One Alternative: Commensurate Discounted Assumption .500

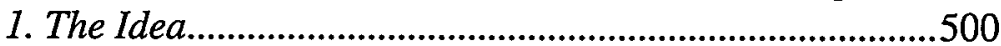

2. Limitations and Implications.........................................502

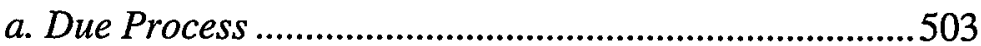

b. Successor Liability Issues ..............................................504

c. Transaction Costs in Claims Resolution ........................505

C. Policing Inclusion of Future Claims ................................505

VI. CONCLUSION: IMPERFECT SOLUTIONS..................................507

Imagine that a small private airplane crashed into your living room. Your arm was broken, but thankfully, none of your loved ones were hurt. You did have something of a sentimental attachment to your living room, which is now in shambles. Times being what they are, you naturally look for someone to sue. Unfortunately, the pilot of the plane was not as lucky as you. Her demise eliminates one potential defendant. So you look to the manufacturer. It turns out the 
manufacturer went into bankruptcy last year, selling its business lock, stock and barrel to another company. Afterward, it dissolved.

Except for the fact that the manufacturer no longer existsyour lawyer informs you-you would have had a good cause of action against it. However, you might be able to recover from the company that acquired the business. Your prospects may. depend on any or all of the following: (i) the terms of sale between the manufacturer and the acquirer, (ii) any order of the bankruptcy court approving the sale, (iii) whether provision was made in bankruptcy for compensation of future crash victims, (iv) whether the acquirer continues to make a version of the same plane, (v) which state's law applies, and (vi) whether you read the notice in the newspapers last year announcing the manufacturer's bankruptcy and sale of its business.

You scratch your head.

"You" have a problem. You have a claim against a business that is now defunct. Well, not exactly defunct. The business still exists. But it is now owned by an entity different from the one that manufactured the airplane that changed your life. At the time of the manufacturer's bankruptcy and sale of its business, neither the manufacturer nor the acquirer knew of your existence. While they probably anticipated that a certain number of planes would crash over time, there would have been no way to identify you as a future crash victim or to quantify your particular damages. One consequence of the sale is that you may be left with no means of recovery. You may be surprised to find that there is "no great wrong" to be redressed." At the time of the sale, you were merely a future claimant.

\footnotetext{
${ }^{1}$ Cf. In re Piper Aircraft Corp., 162 B.R. 619, 625 n.9 (Bankr. S.D. Fla. 1994), aff'd, Epstein v. Official Comm. of Unsecured Creditors of Estate of Piper Aircraft Corp. (In re Piper Aircraft Corp.), 58 F.3d 1573 (11th Cir. 1995). In the process of disallowing a $\$ 100,000,000$ claim filed on behalf of future claimants, the court opined that no provision need be made for them because there was "no "great wrong"" to be redressed. Id. Whereas in certain mass tort cases, the court reasoned, manufacturers had produced and distributed products known to be harmful, only a very small percentage of the debtor's extant fleet of aircraft would crash because of manufacturing or design defects. The now-famous Piper decision is more fully discussed infra Part III(C)(2).
} 


\section{INTRODUCTION}

While the term "future claim" came into vogue with the mass tort cases, ${ }^{2}$ future claims plagued the legal system long before asbestos became a household word. Whenever a firm sells its business and subsequently dissolves, it leaves behind potential liabilities that might go unpaid. ${ }^{3}$ If the business is a manufacturing business, a product of its manufacture may cause injury long after the enterprise is sold and the original corporation has disappeared. ${ }^{4}$ The sale and dissolution marks a day of reckoning among the acquirer of the business, the selling or target firm, and its creditors and shareholders. ${ }^{5}$ Assets and liabilities are valued and divvied up between acquirer and target, and consideration is paid to the target. The target firm will then dissolve, paying its creditors from the proceeds of the sale, distributing any surplus to shareholders, and then disappearing. Future claims, however, defy facile treatment on the day of reckoning. "Future claims" are those potential future products liabilities that exist on the day of reckoning. The manufacturer's liability-creating conduct has already occurred, but any harmful consequence has yet to appear. ${ }^{6}$

Ordinarily, when the business is sold-whether inside or outside of bankruptcy-future claims are ignored. ${ }^{7}$ The future claimant and

${ }^{2}$ See generally John C. Coffee, Jr., Class Wars: The Dilemma of the Mass Tort Class Action, 95 ColuM. L. REv. 1343 (1995) [hereinafter Coffee, Class Wars]; John C. Coffee, Jr., The Corruption of the Class Action: The New Technology of Collusion, 80 CORNELL L. REV. 851 (1995) [hereinafter Coffee, The Corruption of the Class Action]; Mark J. Roe, Bankruptcy and Mass Tort, 84 ColUM. L. REV. 846 (1984) [hereinafter Roe, Mass Tort].

${ }^{3}$ While the firm could take one of several different forms, this Article assumes the firm's use of the corporate form. The transactions that implicate future claims and successor liability are almost always between corporations.

${ }^{4}$ A similar problem involves future environmental liability under CERCLA, the Comprehensive Environmental Response Compensation and Liability Act, 42 U.S.C. \$9601-9675 (1994), and similar state statutes. See generally Michael D. Green, Successors and CERCLA: The Imperfect Analogy to Products Liability and an Alternative Proposal, 87 Nw. U. L. REV. 897 (1993) [hereinafter Green, Successors and CERCLA]; Kathryn R. Heidt, Environmental Obligations in Bankruptcy: A Fundamental Framework, 44 FLA. L. REV. 153 (1992). While future environmental liabilities lend themselves to analysis similar to future products liability, this Article will focus on the latter, and the term "future claim" will refer to future products liability claims only.

${ }^{5}$ Cf. Douglas G. Baird, The Uneasy Case for Corporate Reorganizations, 15 J. LEGAL STUD. 127, 127 (1986) [hereinafter Baird, The Uneasy Case] (describing bankruptcy as "a day of reckoning for all parties with ownership interests in an insolvent firm").

${ }^{6}$ For example, the defective manufacture of an aircraft and its release into commerce may ultimately result in liability for the manufacturer. Any harm, however, may arise only decades after the manufacture of the aircraft. See infra notes 12-13 and accompanying text.

${ }^{7}$ At the time of sale, future tort injuries may not even have been contemplated. However, in many cases, the nature of the product-related injuries at issue were or could reasonably have been anticipated at the time of sale. See, e.g., Epstein v. Official Comm. of Unsecured Creditors of Estate of Piper Aircraft Corp. (In re Piper Aircraft Corp.), 58 F.3d 1573 (11th Cir. 1995) (involving future plane crashes); Western Auto Supply Co. v. Savage Arms, Inc. (In re Savage 
her future injuries are not vivid to the corporate tortfeasor, the acquirer, or any other relevant observer. ${ }^{8}$ At the time of sale and dissolution, it may be difficult to estimate the aggregate amount of future liability. It may not be possible even to identify, or describe except in general terms, the individuals who may later suffer injury. ${ }^{9}$ They may be ascertainable only years after the business has been sold. A future claimant's rights are considered only in retrospect-that is, when her injury occurs-if at all.

Consider the future claimant's precarious position. The day of reckoning may have come and gone without her knowledge. She may not have known about the sale and dissolution. Even if she had known, she may have had absolutely no relationship or connection with the manufacturing firm at the time of sale. Even if she had had some connection-for example, as a consumer of its product-she may not have imagined that she could become an obligee of the manufacturer. She would not have been concerned about the day of reckoning or any possible effect of the sale and dissolution on her abstract legal rights. And even if she had understood in the abstract that her legal rights might be affected, she would not likely have taken any action. Given the remoteness of any possible injury, she would not have made a claim or invested resources to participate in any available legal process. ${ }^{10}$ As a practical matter, the future claim-

Indus., Inc.), 43 F.3d 714 (1st Cir. 1994) (involving defective firearm); Ray v. Alad Corp., 560 P.2d 3 (Cal. 1977) (involving defective ladder).

${ }^{8}$ See generally RICHARD NISBETT \& LEE ROSS, HUMAN INFERENCE: STRATEGIES AND SHORTCOMINGS OF SOCIAL JUDGMENT 43-62 (1980) (finding that cognitive processes tend to lead us to overemphasize information that is most concrete and "vivid"); Roe, Mass Tort, supra note 2, at 855 (noting society's willingness to spend more on current identifiable victims and less on future statistical victims despite expert consensus that dollars are better spent on latter); Thomas A. Smith, A Capital Markets Approach to Mass Tort Bankruptcy, 104 Y ALE L.J. 367, 383 (1994) (noting in the mass tort context that "[p]resent claimants have powerful psychological advantages over future claimants in their battle to maximize their share of the debtor's estate. Present claimants in mass tort bankruptcies are identifiable persons with urgent medical and financial needs, while future claimants are only statistical probabilities."); Shelley E. Taylor \& Suzanne C. Thompson, Stalking the Elusive "Vividness" Effect, 89 PsYCHOL. REV. 155 (1982) (questioning evidence supporting vividness effect, but proposing salience-vividness effect to explain differential impact of vivid information under conditions of information competition).

${ }^{9}$ The universe of plane crash victims, for example, is not limited to owners or passengers. It would therefore be impossible to identify, even in general terms, the class of persons who might ultimately suffer injury from a defective airplane. Similarly, the entire universe of individuals who have ever been exposed to asbestos fibers would also be difficult to capture, given the once pervasive use of asbestos as an insulating material in construction. See infra note 100 and accompanying text.

${ }^{10}$ If at the time of sale and dissolution, an individual's chances of ultimately sustaining injury are low, it may be difficult to convince her to invest resources today in a proceeding that will affect her, if ever, only years into the future. The expected value to any given individual of such an investment is likely negative, even if any ultimate injury might be severe. See Roe, Mass Tort, supra note 2, at 898-99 ("Individuals . . . often disregard serious risks that have a low probability of occurring."); Alan Schwartz, Products Liability, Corporate Structure, and Bank- 
ant will have had no opportunity to assert her rights and to be counted on the day of reckoning.

Much may be at stake in whether unknown future tort creditors are compensated. The phenomenon of long-tail products liability is now commonplace. ${ }^{11}$ With modern design, engineering and materials, many is the product that will stay in circulation long after its original manufacturer has sold its business and disappeared. ${ }^{12}$ In addition, modern production and distribution enable widespread sale and use of a product long before harmful effects may become apparent to the public. $^{13}$ There may have been a day when the possibility of future

ruptcy: Toxic Substances and the Remote Risk Relationship, 14 J. LEGAL STUD. 689, 725-26 (1985) (discussing disincentives for future claimants to trigger manufacturer's banknuptcy); see also RICHARD B. SOBOL, BENDING THE LAW: THE STORY OF THE DALKON SHIELD BANKRUPTCY 107-15 (1991) (describing debate over whether notice to future claimants conceming claims bar date in bankruptcy could ever be adequate, given that future claimants in perfect health at time of notice would likely fail to appreciate its significance and would not likely file proof of claim).

${ }^{11}$ See generally Green, Successors and CERCLA, supra note 4, at 904-06 (discussing longtail products and environmental liabilities and inadequacy of traditional corporate law dissolution statutes in dealing with them); Kathryn R. Heidt, The Changing Paradigm of Debt, 72 WASH. U. L.Q. 1055 (1994) [hereinafter Heidt, Changing Paradigm] (describing "extraordinary liabilities" in bankruptcy); Wendy E. Wagner, Choosing Ignorance in the Manufacture of Toxic Products, 82 CORNELL L. REV. 773 (1997) (describing dearth of even minimal level of safety research concerning long-term health effects of chemicals widely used in commerce, and incentives under current law for manufacturers not to perform such research but, rather, to build litigation defense strategies around ignorance).

${ }_{12}$ At the time of the Piper Aircraft bankruptcy, there were an estimated 95,000 Piper planes still in existence worldwide, and the average age of a Piper aircraft still flying was twenty-four years. See Amended Disclosure Statement Pursuant to Section 1125 of the Bankruptcy Code with Respect to the First Amended Joint Chapter 11 Plan of Reorganization of the Debtor, the Official Committee of Unsecured Creditors of Piper Aircraft Corporation, Newco Pac, Inc., Teledyne Industries, Inc. and Dimeling, Schreiber and Park, In re Piper Aircraft Corp., (Bankr. S.D. Fla. 1994) (No. 91-31884-BKC-RAM) [hereinafter Piper Disclosure Statement]; see also Polius v. Clark Equip. Co., 802 F.2d 75 (3d Cir. 1986) (involving 1983 accident with machine manufactured in 1969); In re RegO Co., 623 A.2d 92, 100 (Del. Ch. 1992) (noting actuarial forecasts showing that future claims involving industrial valve products would arise for twenty to thirty years following dissolution); Dawejko v. Jorgensen Steel Co., 434 A.2d 106 (Pa. Super. Ct. 1981) (involving 1972 accident with machine manufactured in 1957). As one writer noted:

Insurance industry statistics. . . suggest that only thirty percent of expected general

liability claims (which include products liability) are reported three years after the initial policy year and only sixty percent are reported after the eighth year. Not until thirteen years after the initial policy year are seventy-five percent of the losses known to the insurer. The balance of these losses develop over the next two decades.

Mark R. Sarlitto, Note, Recognizing Products Liability Claims at Dissolution: The Compatibility of Corporate and Tort Law Principles, 87 CoLUM. L. REV. 1048, 1052 (1987) (citing REINSURANCE ASS'N OF AMERICA, LOSS DEVELOPMENT STUDY: 1985 EDITION 5 (1985)).

${ }^{13}$ The latency period for asbestos-produced disease may run as long as forty years. See Christopher F. Edley, Jr. \& Paul C. Weiler, Asbestos: A Multi-Billion Dollar Crisis, 30 HARV. J. ON LEGIS. 383, 387-88 (1993).

When businesses purposefully conceal harmful effects after their discovery, the problem is of course exacerbated. See PAUL BROdeUR, OUTRAgeOus MisconduCT: THE ASBestos INDUSTRY ON TRIAL 141-46 (1985) (claiming that executives of Johns-Manville and other asbestos producers actively suppressed evidence of harmful effects of exposure); SOBOL, supra note 10, at 1-22 (chronicling A.H. Robins's history of ignoring safety research showing dangers 
products liability claims caused little concern when a business was sold. Insignificant in terms of both number and severity, such future claims may simply not have been worth worrying about. ${ }^{14}$ That day, however, has passed.

While this Article focuses primarily on bankruptcy sales, it begins with a discussion of sales outside the bankruptcy context, providing background for the subsequent formulation of a bankruptcy prescription. Outside of bankruptcy, courts devised a rule of successor liability that attempts to strike a rough accommodation of competing interests. When applicable, this rule allows the future claimant to recover from the acquirer if the manufacturer is unavailable. However, only a minority of states have adopted this rule, and it offers only sporadic relief to future claimants. ${ }^{15}$

The proper treatment of future claims in bankruptcy is likewise an unsettled question among both courts and commentators. Courts have struggled over two fundamental issues: (1) whether a future claimant qualifies as a "creditor" whose rights may be affected by bankruptcy generally, and (2) whether authority may be found in the Bankruptcy Code to extinguish future claimants' successor liability rights following a bankruptcy sale. The confusion should not surprise. The courts have been left with the unenviable task of apportioning losses, both realized and remote, in the face of scarce resources and with little statutory guidance.

Unlike the courts, bankruptcy theorists agree on several fundamental points. They agree that future claims may appropriately be handled as part of the bankruptcy process-that is, included as bankruptcy claims. Further, if the bankruptcy results in a sale of the business, then provided future claimants' rights are recognized in bankruptcy, their successor liability rights should be extinguished. ${ }^{16}$

However, theorists disagree as to the universality of the bankruptcy model. They disagree as to whether future claims must always be included in bankruptcy, ${ }^{17}$ or whether their inclusion should depend

associated with use of Dalkon Shield); Wagner, supra note 11, at 823-24 (describing concealment of adverse safety testing results in marketing of breast implants and tobacco, as well as asbestos and Dalkon Shield).

${ }^{14}$ Providing for recoveries to future claimants would have been relatively expensive when compared with the amount of accident costs that would otherwise have been left unsatisfied. $C f$. RICHARD A. POSNER, ECONOMIC ANALYSIS OF LAW 214 (4th ed. 1992) (explaining that the traditional corporate law rule of no successor liability "reflects a time when delayed tort consequences were less common than they are today, so that the transaction costs of successorship liability dominated the externalization of accident costs").

${ }^{15}$ See infra Part II.

${ }^{16}$ See infra notes 202, 228-31 and accompanying text

${ }^{17}$ See infra note 90 and accompanying text. 
on the debtor's discretion ${ }^{18}$ - what I refer to as the "flexible" approach. Ironically, at a time when some scholars have called for fundamental corporate and commercial law reform to protect tort claimants from the liability avoidance that existing rules permit, ${ }^{19}$ certain bankruptcy commentators-including the National Bankruptcy Conference ("NBC") and the National Bankruptcy Review Commission ("NBRC") ${ }^{20}$-advocate a more instrumental approach, content to ignore future tort claims in bankruptcy if the needs of the debtor and current creditors so require.

In this Article, I propose a two-part prescription for the proper disposition of future claims when a business is sold in bankruptcy. First, I argue that in a bankruptcy proceeding through which a business is sold, future claims must be included and treated on a par with other unsecured creditors. Second, provided future claimants' rights are thus recognized in bankruptcy, any related successor liability rights must be extinguished.

This Article makes three related contributions to the existing literature. First, I show that in the bankruptcy sale context, leaving to the debtor's discretion the decision whether to include future claims merely enables future claimants' exploitation. ${ }^{21}$ For the most part, neither advocates for the flexible approach nor for mandatory inclusion of future claims have focused on the bankruptcy sale context and its exploitive potential.

Second, I argue that bankruptcy courts do and should have the power to enjoin successor liability claims following a bankruptcy sale in which future claimants' rights are respected. I assert that such an injunction is the functional equivalent in a going concern bankruptcy sale to the Chapter 11 discharge in internal reorganization, and therefore that such an injunction is within the inherent equitable powers of bankruptcy courts.

Finally, I tackle the practical implications of the scheme I advocate. Recognizing that for many debtors, the current "traditional" approach to treatment of future claims-pioneered in the mass tort

\footnotetext{
${ }^{18}$ See infra notes $82-83$ and accompanying text.

19 See infra note 237 and accompanying text. The approach advocated herein assumes the current state of corporate limited liability and creditor priority rules. This Article also takes no position with respect to the common law tort system as a method of setting and delivering compensation, but for present purposes takes the current system as given.

${ }^{20}$ See infra note 93 and accompanying text.

${ }^{21}$ Future claims may also be included when the business is internally reorganized. However, a flexible approach may be acceptable in internal reorganization. See infra notes 145-46 and accompanying text. The sale context will be this Article's primary focus, because it more strongly implicates liability avoidance concerns. See infra notes $145-47$ and accompanying text.
} 
bankruptcies - may generate transaction costs disproportionate to the amounts at stake, I introduce an approach I call Commensurate Discounted Assumption ("CDA"), in which the acquirer assumes at a discount the debtor's liability for future claims. This approach sidesteps the uncertainty of the formal estimation that is critical to the traditional approach and avoids some of the costs of that approach.

Part II provides background. In it, I first describe the successor liability doctrine. Then I describe bankruptcy reorganization and bankruptcy sales. In Part III, I discuss inclusion of future claims in reorganization. I describe the mass tort cases, in which future claims have been included, and contrast them with ordinary cases, in which future claims are typically ignored. I discuss the impetus behind the flexible approach and criticize its application to the bankruptcy sale context. In Part IV, I describe the bankruptcy power to extinguish successor liability claims. In Part V, I comment on the practical implications of the scheme I advocate and discuss possible approaches, including my CDA approach.

\section{BACKGROUND}

Careful structuring of the sale of an enterprise may enable corporate planners to free the business from the claims of future tort victims, allowing the acquirer and the seller's shareholders to share the gains from this "laundering" of assets." Such sales occur both within and outside of bankruptcy. This Part first describes the predicament of future claimants outside of bankruptcy and the common law doctrine of successor liability that emerged to address their special vulnerability. This Part then describes bankruptcy reorganization and introduces the problem of future claims in the bankruptcy sale context.

\section{A. Form and Substance in the Sale of a Business}

Corporate planners structuring the sale of a business have two standard transactional models from which to choose-the merger and the sale of assets. ${ }^{23}$ Each has its own benefits and costs. The structuring of a given transaction has important consequences for credi-

\footnotetext{
${ }^{22}$ See infra note 31 and accompanying text.

${ }^{23}$ There are, of course, infinite variations on the standard models. See generally RONALD J. GLSON \& BERNARD S. BLACK, THE LAW AND FINANCE OF CORPORATE ACQUISTIIONS 641, 728 (2d ed. 1995) (dedicating a chapter to explaining the multiple techniques for acquisitions).
} 
tors, shareholders and other stakeholders of both acquirer and target, ${ }^{24}$ as well as for the public fisc. ${ }^{25}$ From the planner's perspective, one benefit from the sale of assets structure is its potential to free the business from liability to future tort claimants.

The merger device provides a neat and tidy "off the rack" method of acquisition that tends to minimize disruption of the existing legal and other relationships of the corporations involved. ${ }^{26}$ In the standard merger, the acquiring company pays consideration to the shareholders of the target company in exchange for the target's business, and the target company merges into the acquirer. The acquirer as the surviving entity succeeds to the assets and liabilities of the target by operation of law. ${ }^{27}$ The legal existence of the target company ends as a result of the merger, but the surviving company remains liable to the target's creditors. ${ }^{28}$

The tidiness of this arrangement presents drawbacks, however, if the acquirer wishes to be selective about which assets of the target it will acquire or which liabilities it will assume. If the acquirer wants the lock and stock but not the barrel, then an asset sale may be the preferred acquisition technique. Under this arrangement, the acquirer purchases selected assets from-and may assume particular liabilities of-the target. This technique may be useful in enabling the acquirer to avoid, or at least minimize, exposure to certain of the target's creditors, ${ }^{29}$ an option not available under the merger form.

When the acquirer buys the assets of its target, generally only the assets transfer. The liabilities do not automatically follow. The ac-

\footnotetext{
${ }^{24}$ See generally John C. Coffee, Jr., The Uncertain Case for Takeover Reform: An Essay on Stockholders, Stakeholders and Bust-Ups, 1988 WIS. L. REV. 435 (discussing use of state antitakeover legislation to protect stakeholders from effects of corporate takeovers).

${ }^{25}$ See generally BORIS I. BITTKER \& JAMES S. EUSTICE, FEDERAL INCOME TAXATION OF CORPORATIONS AND SHAREHOLDERS ch. 14 (6th ed. 1994) (discussing tax consequences for different forms of acquisitions).

${ }^{26}$ See GILSON \& BLACK, supra note 23, at 642.

At one moment two corporations exist; at the next, the acquiring corporation has enveloped the target, like an amoeba engulfing its prey, and has succeeded to all of its properties, rights and other attributes. The technique has significant advantages in reducing the transaction costs associated with the mechanical aspects of accomplishing an acquisition.... The effect of statutory [merger] provisions . . . is to substitute a single document, the merger agreement, for the flood of paper that would otherwise be required to effect the transaction.

Id.

${ }^{27}$ See, e.g., CAL. CORP. CODE § 1107 (West 1990); DEL. CODE ANN. tit. 8, § 259(a) (1997); MODEL BUS. CORP. ACT $\$ 11.06(a)(3)$ (1994).

28 "A statutory merger provides the most protection.... [C]reditors of the target company are protected because the surviving company in a merger assumes as a matter of law all of the target's liabilities, including unknown or contingent liabilities." GILSON \& BLACK, supra note 23 , at 1503 .

${ }^{29}$ Mergers also implicate shareholder consent requirements and other protections, which may give corporate planners further incentive to avoid mergers in favor of asset sales. See id.
} 
quirer, a legal entity separate and distinct from the target, does not succeed to the target's liabilities absent specific agreement otherwise. $^{30}$ As a matter of economic substance, a business enterprise may be transferred, but the liabilities associated with that business remain with the target firm, absent some exception to this general rule. ${ }^{31}$

By itself, the asset sale does nothing to prejudice the target's creditors. As long as the target entity receives fair consideration for its assets and remains in existence to satisfy its liabilities, creditors of the target have nothing to fear. However, once a target entity sells its business, it typically will dissolve. With no business left to operate, the target entity has no further reason to exist. Because it is left with only the sale consideration-usually cash, marketable securities or some combination - the target will dissolve, paying its known creditors and distributing any remaining assets to its shareholders.

The typical state corporation statute requires only that the dissolving corporation pay or provide for its known debts as a condition to dissolution. ${ }^{32}$ Unknown claims at the time of dissolution-in particular, future products liability claims-may be prejudiced by the dissolution. ${ }^{33}$ The corporate tortfeasor has disappeared, and the shareholders who received the corporation's surplus are largely immune to suit. While states generally provide a post-dissolution period within which suit may be brought, ${ }^{34}$ and shareholders may be required

\section{${ }^{30}$ See id.}

31 As Professor Carlson has noted, "[C]orporate lawyers soon learned that by avoiding mergers and substituting sales of assets instead, the assets of a debtor might be laundered and its creditors' claims against the buyer effectively eliminated." David Gray Carlson, Successor Liability in Bankruptcy: Some Unifying Themes of Intertemporal Creditor Priorities Created by Running Covenants, Products Liability, and Toxic-Waste Cleanup, 50 LAW \& CONTEMP. PROBS. 119, 127 (1987). (1994).

${ }^{32}$ See, e.g., CAL. CORP. CODE $\S 2004$ (West 1990); MODEL BUS. CORP. ACT $\$ 14.06 \mathrm{cmt}$.

${ }^{33}$ Claims that have not arisen under state law at the time of dissolution are generally not considered known debts. See Peñasquitos, Inc. v. Superior Court, 812 P.2d 154, 161 (Cal. 1991) (citing Ray v. Alad Corp., 560 P.2d 3, 9 (Cal. 1977)); see also MODEL Bus. CORP. ACT § 14.06 cmt. (1994) ("[A] claim that is contingent or has not matured so that there is no immediate right to bring suit is not a 'known' claim.").

${ }^{34}$ See, e.g., CAL. CORP. CODE $\$ 2011$ (a)(2)(B) (West Supp. 1999) (four years); DEL. CODE ANN. tit. 8, § 278 (1997) (three years); MODEL BUS. CORP. ACT $\$ 14.07$ (c) (1994) (requiring for unknown claim that suit be brought within five years from date of publication notice of dissolution).

Delaware now provides incrementally more protection for unknown creditors. Upon dissolution, provision must be made that will "be reasonably likely to be sufficient" to compensate unknown claims that "based on facts known to the corporation ... are likely to arise or to become known ... within 10 years after the date of dissolution." DEL. CODE ANN. tit. 8, § 281(b) (1997). The dissolved corporation may, during the winding up process, petition the Chancery Court for a determination concerning the proper amount and form of security to satisfy the above prescription. The court determination process also holds out the possibility of shortening the "tail" period to five years. See id. $\S 280$ (c)(3). The court may appoint a guardian ad litem to represent unknown claimants, with the guardian's reasonable fees and expenses paid by the 
to disgorge post-dissolution distributions in satisfaction of such suits, this liability is typically limited. A shareholder will be liable only for the lesser of (1) the amount of any distribution received and (2) her pro rata share of the late-appearing creditor's claim. ${ }^{35}$ This limitation, along with the costs of pursuing individual shareholders-locating them, fighting possible jurisdictional issues, judgment-proof defendants-makes this an unattractive prospect for future tort victims. ${ }^{36}$

In any particular enterprise, the aggregate amount of future tort liability may be large enough to worry about. Therefore, in structuring these types of transactions, purchasers and sellers have incentive to avoid future liabilities. ${ }^{37}$ Even absent opportunism on the part of purchasers and sellers, the pervasiveness of long-tail liabilities suggests that the aggregate liability-avoiding effects of corporate dissolution may be significant.

\section{B. Successor Liability}

Into this breach stepped the courts, or at least some of them. Over time, these courts developed enterprise-based approaches to address liability avoidance through asset sale, ${ }^{38}$ crafting exceptions to the basic rule that the acquirer of assets does not inherit the target's liabilities. These exceptions, the "business continuation" exception and the

petitioning corporation. See id.; see also In re RegO Co., 623 A.2d 92 (Del. Ch. 1992) (deciding the first case involving a challenge to dissolution plan under predecessor to current statute).

Even an extended tail period, however, may prove ineffective to provide substantial coverage for future products liability claimants. See supra notes 12-13 and accompanying text.

${ }^{35}$ See, e.g., CAL. CORP. CODE $\$$ 2011(a)(1)(B) (West Supp. 1999); DEL. CODE ANN. tit. 8 , $\S 282$ (1997); MODEL BUS. CORP. ACT $§ 14.07$ (d) (1994).

${ }_{36}$ Other possible avenues of recovery from shareholders are likewise unattractive. See Mark J. Roe, Mergers, Acquisitions, and Tort: A Comment on the Problem of Successor Corporation Liability, 70 VA. L. REV. 1559, 1564 n.15 (1984) [hereinafter Roe, Successor Liability] (describing difficulties with common law trust fund and fraudulent conveyance theories).

${ }^{37}$ The existence of such incentives will of course vary from industry to industry, depending on the tort-generating potential of the business. See, e.g., Lynn M. LoPucki, The Death of Liability, 106 YALE L.J. 1, 44-45 (1996) [hereinafter LoPucki, The Death of Liability] (discussing varying incentives to judgment-proof from industry to industry); George L. Priest, The Current Insurance Crisis and Modern Tort Law, 96 YALE L.J. 1521, 1521 (1987) (identifying particular industries and products-vaccines, general aviation aircraft, sports equipment and ski lift operations, among others - subject either to drastically rising insurance premiums or unavailability of coverage at any price).

${ }^{38}$ Courts have been willing under some circumstances to view enterprises rather than entities as the operative units for imposition of liability. See PHILLIP I. BLUMBERG, THE LAW OF CORPORATE GROUPS $§ 18.02$ (1985) (describing with approval evolution from entity principles to enterprise principles in many areas of law); Phillip I. Blumberg, The Increasing Recognition of Enterprise Principles in Determining Parent and Subsidiary Corporation Liabilities, 28 CONN. L. REV. 295, 344 (1996) (citing development of successor liability law as example of growing application of enterprise principles in American law). However, as with other entitybased liability-avoiding strategies, the law will "disregard entities only in extreme circumstances." LoPucki, The Death of Liability, supra note 37, at 67. 
"product line" exception," allow suit against the acquirer by the claimant, unknown at the time of the acquisition, who suffers injury from a product manufactured by the target-that is, the predecessor owner. $^{40}$ In this way, a means of recovery is provided to the future claimant.

\section{The Doctrine}

While the business continuation doctrine and the product line doctrine differ in their origins, ${ }^{41}$ they share the basic idea that if there is economic continuity of the enterprise in the acquirer's hands, then the acquirer should inherit the manufacturer's strict products liability. $^{42}$ Economic continuity means that the substantive effect of the sale is simply to change ownership of the business. Successor liability assures that this enterprise can not duck future tort liabilities through an ownership change. Structuring the transaction as an asset

\footnotetext{
${ }^{39}$ Other exceptions to the general rule of nonliability of the asset acquirer have been recognized where (a) the asset sale is deemed a fraudulent attempt to evade creditors; (b) the purchasing corporation is a mere continuation of the selling corporation; or (c) the acquirer agrees, either explicitly or implicitly, to assume the target's liabilities. See Knapp v. North American Rockwell Corp., 506 F.2d 361 (3d Cir. 1974), cert. denied, 421 U.S. 965 (1975). See generally 15 StePHEN M. FlanAGaN, ET AL., FletCHER CyClopedia of THE LAW OF PRIVATE CORPORATIONS § 7122, at 231 (1991); Michael D. Green, Successor Liability: The Superiority of Statutory Reform to Protect Products Liability Claimants, 72 CORNELL L. REV. 17, 22 (1986) [hereinafter Green, Statutory Reform]; Jerry J. Phillips, Product Line Continuity and Successor Corporation Liability, 58 N.Y.U. L. REV. 906, 908 (1983) [hereinafter J. Phillips, Product Line Continuity].

My focus is on the difficult case, that of the bona fide arm's-length enterprise sale between unaffiliated parties where the acquirer does not agree to assume future tort liabilities.

40 The terms "predecessor," "manufacturer" and "target" are used interchangeably, depending on the context, to refer to the entity that manufactured the product that later causes harm to the future claimant.

${ }^{41}$ See generally Green, Statutory Reform, supra note 39, at 22-26 (describing common law development of successor liability).

${ }^{42}$ See, e.g., Ray v. Alad Corp., 560 P.2d 3, 8 (Cal. 1977) (describing successor's ability to assume original manufacturer's role in spreading risk of defective products); Turner v. Bituminous Casualty Co., 244 N.W.2d 873, 881 (Mich. 1976) (same). As the appellate court stated in Cyr v. B. Offen \& Co., 501 F.2d 1145 (1st Cir. 1974):
}

The very existence of strict liability for manufacturers implies a basic judgment that the hazards of predicting and insuring for risk from defective products are better borne by the manufacturer than by the consumer. The manufacturer's successor, carrying over the experience and expertise of the manufacturer, is likewise in a better position than the consumer to gauge the risks and the costs of meeting them. The successor knows the product, is as able to calculate the risk of defects as the predecessor, is in position to insure therefor and reflect such cost in sale negotiations, and is the only entity capable of improving the quality of the product.

Id. at 1154 . 
sale, as opposed to a merger or stock sale, ${ }^{43}$ will not eliminate these liabilities.

The two approaches differ with respect to the indicia relied upon to determine the requisite economic continuity justifying imposition of successor liability. The business continuation theory essentially adopts a totality of circumstances test, considering such factors as continuity of management or key personnel, continuity of assets or general business operations, retention of the same name and product, and the acquirer's purchase of the predecessor's goodwill. $^{44}$ The product line theory instead turns on the acquirer's continuation of the target's product line-its "undertaking to manufacture essentially the same line of products as the predecessor." 45

${ }^{43}$ With a sale of stock, although the identity of the owners changes, the corporate form of the business remains unchanged, unlike the case of acquisition by merger or asset sale. Therefore, the sale of stock does not affect the liabilities of the target corporation.

${ }^{44}$ See, e.g., Cyr, 501 F.2d at 1152 (stating factors considered in business continuation theory); MacCleery v. T.S.S. Retail Corp., 882 F. Supp. 13, 17 (D.N.H. 1994) (listing a series of factors in determining successor liability under a business continuation theory); Shannon v. Samuel Langston Co., 379 F. Supp 797, 800 (W.D. Mich. 1974) (describing circumstances where sufficient business continuity will be found); see also J. Phillips, Product Line Continuity, supra note 39, at 918-19 (describing business continuation theory).

This exception grew out of the de facto merger doctrine of corporate law, in which the primary focus was shareholder protection. Whereas statutory mergers typically require approval by shareholders of the constituent corporations and provide dissenters rights, corporate planners attempted to avoid these protections by structuring business combinations as asset sales instead. The acquirer would issue its own stock as consideration for the target's assets. The target would then dissolve, distributing this consideration to its own shareholders. As a result, the acquirer swallowed the target's business, and the target's former shareholders became shareholders of the acquirer. Because the end result was the same as a stock merger, courts created the doctrine of de facto merger in order to afford the acquirer's shareholders the same protections to which they would have been entitled in the case of a statutory merger. See, e.g., Farris v. Glen Alden Corp., 143 A.2d 25 (Pa. 1958) (holding that stock-for-assets acquisition constituted de facto merger, triggering shareholder rights of dissent). Courts then imported this approach into the tort area, deeming certain business combinations the functional equivalent of statutory mergers, such that the acquirer should succeed to the target's future tort liabilities. See Knapp v. North American Rockwell Corp., 506 F.2d 361 (3d Cir. 1974 ), cert. denied, 421 U.S. 965 (1975) (discussing corporate law genesis of de facto merger doctrine, and imposing successor liability in stock-forassets acquisition). From there, it was a relatively small step to the conclusion that in the tort context, the merger analogy should apply regardless of whether the sale consideration is stock or cash. See Turner v. Bituminous Casualty Co., 244 N.W.2d 873 (Mich. 1976) (holding that liability does not turn on the form of the acquisition).

This concept is often stated as two distinct exceptions to the general nule of nonliability"business continuation" and "de facto merger." However, the exceptions tend to overlap. "[N]o criteria can be identified that distinguish them in any useful manner. In each instance, the central issue is whether the purchasing corporation effectively has become the selling corporation by acquiring not only the latter's assets but also its entire business." J. Phillips, Product Line Continuity, supra note 39, at 909; see also George L. Lenard, Note, Products Liability of Successor Corporations: A Policy Analysis, 58 IND. L.J. 677, 699-700 (1983) (noting substantial overlap between de facto merger and continuation theories).

${ }_{45}$ Ramirez v. Amsted, 431 A.2d 811, 819 (N.J. 1980). 


\section{Assessment}

Although successor liability provides compensation to otherwise hapless future tort claimants, it has generated much controversy as to both its theoretical justifications ${ }^{46}$ and its practical consequences. Even defenders of the doctrine note its shortcomings, ${ }^{47}$ and its adoption has been far from universal. ${ }^{48}$

Successor liability generates uncertainty and increased costs in business dealings, which may inhibit economically desirable transactions-that is, transfers that place assets into more productive hands. ${ }^{49}$ If the amount and timing of future liabilities are difficult to predict, prospective acquirers will be discouraged. ${ }^{50}$ Even if future liabilities could be determined with precision and without cost, the rule may force piecemeal liquidation of otherwise healthy businesses. Any acquirer will naturally discount its purchase price for the business to account for successor liability risk. If this "successor liability dis-

\footnotetext{
${ }^{46}$ For a comprehensive survey and critique of proffered conceptual justifications for successor liability, see Green, Statutory Reform, supra note 39, at 28-40.

${ }^{47}$ See id. at 41-49 (advocating dissolution-restricting statute as superior altemative to successor liability on numerous grounds).

${ }^{48}$ See Green, Successors and CERCLA, supra note 4, at 908-10 (chronicling the "emergence and demise" of liberal successor products liability doctrine, noting at the time that (1) only four state supreme courts had adopted liberal successor liability rules, (2) six state supreme courts rejected the same between 1985 and 1988, and (3) "virtually every other state court encountering the issue declined to adopt a liberal successor liability rule"). Prognostication of the death of successor liability may have been premature, however. See infra note 54 and accompanying text.

${ }^{49}$ See Green, Successors and CERCLA, supra note 4, at 908-10. See generally LoPucki, The Death of Liability, supra note 37. Professor LoPucki notes:

Whether [an enterprise-based] approach [to assigning liability] could be viable depends on whether there are in fact identifiable, stable boundaries between enterprises. If there are, the courts could discover them on a case-by-case basis. If there are not, the courts would be assigning liability arbitrarily and generating probably intolerable uncertainty for investors.

Id. at 67. Professor LoPucki concludes that a full-blown enterprise liability system is not a workable altemative to an entity-based system that occasionally disregards entities. See id. at 69.

50 The costs of estimating future liabilities and any uncertainty with respect to such estimates will deter prospective acquirers:

The potential imposition of unwanted liability is likely to complicate bargaining and raise transaction costs by requiring the buyer to investigate carefully the future liability it may face. Indeed, the threat of successor liability may cause some negotiations to fail when, for example, the seller's records of products extant prove incomplete and the buyer cannot make a reasonable estimate of the costs that it would face.

Steven H. Schulman, Commentary: Successor Corporation Liability and the Inadequacy of the Product Line Continuity Approach, 31 WAYNE L. REV. 135, 142 (1984); see also Roe, Successor Liability, supra note 36 , at 1561 (noting that successor liability might result in "assets [beingl caged in the hands of a demoralized and disabled management that is unable to sell its operations to a higher-valuing and perhaps more capable user").
} 
count" exceeds the operational value of a business, ${ }^{51}$ the business will be unmarketable as a going concern. ${ }^{52}$ The target would have to pay the acquirer to take the business! Absent bankruptcy, the only alternative to continuing the business would be piecemeal liquidation. ${ }^{53}$

Successor liability, then, provides a blunt and imperfect approach to addressing future claims. Although it offers some hope of recovery for future claimants, this hope comes at some cost. While the controversy over the rule has prevented its widespread adoption, the rule may nevertheless be cause for concern among manufacturers and acquirers. It is a viable theory of recovery in several significant statesincluding California and New York. ${ }^{54}$ Depending on the product, manufacturers and acquirers will ordinarily have no ability to control-and may have little ability to predict-where products will be used or which state's law will apply to any given future products liability action. Ultimately, successor liability leaves unclear signals for manufacturers and acquirers and provides only spotty protection for future claimants.

\section{Bankruptcy Reorganization and Bankruptcy Sales}

Going concern asset sales occur in bankruptcy as well as outside, with the same potentially preclusive effect on future claimants' rights. The target in bankruptcy will attempt to sell the business "free and clear" of successor liability, relying on the bankruptcy system to cleanse the assets of any taint of future claims liability.

\footnotetext{
${ }^{51}$ By "operational value," I mean the going concern value of the operating assets, without consideration of non-operating liabilities such as future tort liabilities.

${ }_{52}$ See Roe, Successor Liability, supra note 36, at 1568.

${ }^{53}$ See Green, Statutory Reform, supra note 39, at 42 . On the other hand, the incremental costs of a rule of successor liability may be overstated. For example, with respect to uncertainty and costs of estimating future tort liabilities, presumably the acquirer would undertake some degree of investigation in any event. Moreover, a rule of no successor liability also has costs. Tort victims are forced to bear losses that may be difficult, if not impossible, to spread. Under such a regime, the predecessor also has perverse incentives to sell the business. Although the predecessor may be the most efficient user of its assets, selling enables liability avoidance that would otherwise be unavailable.

${ }^{54}$ To date, the supreme courts of at least five states-including California, Michigan and New Jersey-have explicitly adopted successor liability. See Ray v. Alad Corp., 560 P.2d 3 (Cal. 1977); Turner v. Bituminous Casualty Co., 244 N.W.2d 873 (Mich. 1976); Ramirez v. Amsted, 431 A.2d 811 (N.J. 1980); Garcia v. Coe Mfg. Co., 933 P.2d 243 (N.M. 1997); Martin v. Abbott Lab., 689 P.2d 368 (Wash. 1984). In addition, it has received approval of lower courts in New York and Pennsylvania. See Hart v: Bruno Machinery Corp., 1998 N.Y. Slip Op. 09487, 1998 WL 770354 (N.Y. App. Div.) (applying product line exception); Hill v. Trailmobile, Inc., 603 A.2d 602 (Pa. Super. Ct. 1992) (same); Dawejko v. Jorgensen Steel Co., 434 A.2d $106 \mathrm{~Pa}$. Super. Ct. 1981) (discussing both business continuation and product line exceptions and explicitly adopting the latter).
} 


\section{Reorganization and the Common Pool}

Bankruptcy is meant to solve a common pool problem among creditors. ${ }^{55}$ It provides a mechanism for collective settlement of the debtor's multiple obligations in one proceeding, through which losses are distributed among creditors. Individual creditor collection efforts are halted in favor of this collective proceeding, which attempts to maximize recoveries for creditors as a group.

The classic common pool problem involves a scarce resourcesay, a pond filled with fish-shared among multiple parties. Individual and group interests may diverge as to the use of the shared resource. For each individual with access to the pond, it might serve her individual interest to harvest as many fish as she can, as fast as she can. But the group would probably be better off setting limits on each individual's catch. If the parties could coordinate and enforce limits on their individual harvesting, they could assure that enough fish remained in the pond to repopulate it indefinitely. The group could assure itself a perpetual source of fish.

However, the parties might be unable to coordinate their decisionmaking. Or they might be unable to enforce any collective decision. If the group is unable to limit each individual's harvest, then it makes sense for each individual to pursue her own self-interest. This leads, unfortunately, to the destruction of the pond as a resource. ${ }^{56}$

In bankruptcy, the debtor's assets are the common pool. Creditors are the parties with access to the common pool once the debtor is in financial distress. Absent imposition of bankruptcy's collective proceeding, under state law collection rules, the debtor's assets are divvied on a first-come, first-served basis. Creditors race against each other to seize assets in satisfaction of their respective debts. ${ }^{57}$ While the speedy creditor may do well, creditors as a group are worse off than if they could coordinate their collection efforts, which is usually

\footnotetext{
5s See generally Garrett Hardin, The Tragedy of the Commons, 162 SCI. 1243 (1968) (describing ruination of shared resources from individual pursuit of self-interested ends).

Whether this is the goal or only one among several possibly competing goals is subject to debate. Compare Douglas G. Baird \& Thomas H. Jackson, Corporate Reorganizations and the Treatment of Diverse Ownership Interests: A Comment on Adequate Protection of Secured Creditors in Bankruptcy, 51 U. CHI. L. REv. 97, 100-01 (1984) (asserting that core purpose of bankruptcy law is to reduce costs associated with diverse ownership interests in debtor), with Elizabeth Warren, Bankruptcy Policymaking in an Imperfect World, 92 MICH. L. REv. 336 (1993) (describing multiple and competing policy goals of the bankruptcy system).

${ }^{56}$ See THOMAS H. JACKSON, THE LOGIC AND LIMITS OF BANKRUPTCY LAW 10-13 (1986) [hereinafter JACKSON, LOGIC AND LMMTS] (describing bankruptcy as a device to solve common pool problems among creditors).

${ }^{57}$ See ELIZABETH WARREN \& JAY LAWRENCE WESTBROOK, THE LAW OF DEBTORS AND CREDTTORS 69 (3d ed. 1996) (describing creditors' race of diligence under state law).
} 
impossible under state law. ${ }^{58}$ The race to the debtor's assets results in piecemeal dismemberment of the debtor's business, forsaking going concern value that could have been applied to satisfy creditor claims. ${ }^{59}$

Chapter 11 reorganization coordinates collection activity in order to benefit creditors as a group. It attempts to maximize creditor recoveries by preserving the going concern value of the business. The debtor's management remains in place, ${ }^{60}$ authorized to continue ordinary course operations, ${ }^{61}$ while creditors and the debtor negotiate a plan of reorganization. ${ }^{62}$ Creditors must approve any plan, ${ }^{63}$ but for the duration of the case, the automatic stay precludes individual creditor collection efforts against the estate. ${ }^{64}$ The confirmed plan serves as the blueprint for the reorganized debtor's capital structure, specifying what each creditor receives in consideration for its claim. Typical plan consideration will be either a new scaled-down claim against the reorganized debtor, cash, or some combination. Creditors must await confirmation of the plan in order to receive their plan consideration, which is their exclusive recovery from the estate. Upon confirmation, all preconfirmation debts are discharged, ${ }^{65}$ and creditors are enjoined from pursuing the reorganized debtor on any preconfirmation debt. ${ }^{66}$

Two fundamental norms underlie this system of loss distribution: absolute priority and equal treatment. Under the absolute priority rule, a class of unsecured claims or interests is not entitled to any bankruptcy distribution unless and until each senior class either con-

\footnotetext{
${ }^{58}$ See Daniel L. Keating, Getting a Handle on Late-Manifesting Claims: A Comment, 72 WASH U. L.Q. 1095, 1099 (1994) (describing transaction cost and holdout problems hindering voluntary collective action under state law collection regime).

${ }^{59}$ Even if there is no going concern value, such that piecemeal liquidation is the best disposition of the assets, an orderly liquidation will likely garner more proceeds overall than an uncoordinated fire sale.

${ }^{60}$ See 11 U.S.C. $\$ 1107$ (1994).

${ }^{61}$ The debtor is authorized to use, sell, or lease assets of the estate in the ordinary course of business (except for cash collateral). See id. $\S 363$ (c). The debtor may also incur unsecured debt in the ordinary course of business as an administrative expense. See id. $\S 364$ (a).

${ }^{62}$ See Frederick Tung, Confirmation and Claims Trading, 90 Nw. U. L. REv. 1684, 168999 (1996) (describing Chapter 11 plan negotiation).

${ }^{63}$ Creditors vote by class. See 11 U.S.C. $\$ \$ 1126(c), 1129$ (a)(8) (1994).

${ }^{64}$ See id. \$ 362 . The bankruptcy estate includes "all legal or equitable interests of the debtor in property as of the commencement of the case." Id. $\S 541$ (a)(1).

${ }^{65}$ See id. § 1141(d)(1)(A).

${ }^{66}$ See id. \$ 524(a).
} 
sents or is paid in full. ${ }^{67}$ The rule of equal treatment requires that similarly situated creditors receive equality of treatment. ${ }^{68}$

\section{Future Claims and the Common Pool}

Future claims present a unique challenge for bankruptcy's solution to the common pool problem. ${ }^{69}$ Given that the identities of future claimants and the amounts and timing of their respective claims may be difficult to ascertain at the time of bankruptcy, coordinating bankruptcy's collective settlement becomes quite complicated. As discussed below, incorporating future claims into the settlement may be expensive in transaction cost terms. ${ }^{70}$ On the other hand, leaving them out creates a holdout problem that bankruptcy is specifically designed to cure. ${ }^{71}$ A collective settlement that fails to include future claimants may be ineffective to preserve the value in the common pool. A current claimant would naturally be reluctant to limit her ability to grab assets if she knew that later arriving claimants would not be so restricted. And even if she could be restrained from selfhelp indefinitely, the specter of unresolved future asset grabbers might destroy going concern value today. ${ }^{72}$

\section{The Bankruptcy Sale}

Instead of reorganizing internally, the parties in interest may decide to sell the assets of the estate as a going concern. While we gen-

\footnotetext{
${ }^{67}$ See id. $\$ 1129(\mathrm{~b})(2)(\mathrm{B})$; see also Tung, supra note 62, at 1692-93 (explaining rule of absolute priority).

${ }^{68}$ See Begier v. Internal Revenue Service, 496 U.S. 53, 58 (1990) ("Equality of distribution among creditors is a central policy of the Bankruptcy Code. According to that policy, creditors of equal priority should receive pro rata shares of the debtor's property.").

${ }^{69}$ Some have questioned the applicability of the common pool model to bankruptcy. See, e.g., Randal C. Picker, Security Interests, Misbehavior, and Common Pools, 59 U. CHL. L. REv. 645 (1992). Professor Picker notes that the classic common pool problem involves an overlapping distribution of rights among strangers, but that for the most part the debtor and its creditors are not strangers. Their prebankruptcy relationships enable contracting that can minimize the common pool problem. Therefore, according to Professor Picker, bankruptcy is more accurately modeled as a small decision making problem embedded in a larger one-that is, an embedded game-and not as a simple free-standing common pool problem. See id. at 647-49.

Future claimants, of course, are not voluntary creditors. They and the other involuntary creditors have no real opportunity to negotiate their way around common pool problems. That they are strangers to each other and to contract creditors suggests that the common pool model continues to be useful. Cf. Barry E. Adler, Financial and Political Theories of American Corporate Bankruptcy, 45 STAN. L. REV. 311 (1993) (explaining political basis for laws that effectively preclude creditors from contracting around common pool problem).

30 See infra Part III(C).

${ }^{71}$ See JACKSON, LOGIC AND LIMITS, supra note 56, at 13 (noting collective and compulsory nature of bankruptcy proceeding); Keating, supra note 58, at 1099.

72 See infra note 99 and accompanying text for a description of the operational collapse that may occur because of the existence of overhanging future liabilities that are not susceptible of comprehensive settlement.
} 
erally conceive of the former as "reorganization" and the latter as "liquidation," the two alternatives are not so dissimilar. In both cases, going concern value is preserved while a new capital structure is created for the business. As Dean Baird and President Jackson have explained, one can conceptualize reorganization as a hypothetical sale of the going concern to prepetition creditors, who "purchase" their postbankruptcy participations in the business with their prepetition claims. $^{73}$

The primary difference between internal reorganization and the going concern sale is simply the identity of the investors in the business at the end of the day. With internal reorganization, prepetition creditors constitute the reorganized debtor's postpetition investors. With the going concern sale, the common pool of estate assets is exchanged for cash (or securities or whatever other consideration is paid for the business). Creditors relinquish their prepetition claims in return for shares of this new pool, and the third party purchaser owns the business. ${ }^{74}$ Créditors' claims are paid out of the sale consideration in absolute priority order, respecting as well the rule of equal treatment. ${ }^{75}$ This going concern sale may therefore be conceived of as an "external reorganization."

As is the case outside of bankruptcy, proceeds of the bankruptcy sale, and therefore creditor recoveries, will be maximized if the going concern is sold free of existing liabilities. The typical acquirer will prefer to buy the business "clean," and the bankruptcy court will approve the sale "free and clear" of pre-bankruptcy liabilities. ${ }^{76}$ However, if some of those pre-bankruptcy liabilities are future claims, then the external reorganization scenario may implicate successor liability concerns. As with asset sales outside of bankruptcy, future claims are ordinarily ignored in external reorganization. How they should be treated, and whether successor liability may survive a bankruptcy sale, are unsettled questions that are addressed, respectively, in the next two Parts.

\footnotetext{
${ }^{73}$ See JACKSON, LOGIC AND LIMITS, supra note 56, at 210-11 (describing reorganization as a form of asset sale); Baird, The Uneasy Case, supra note 5, at 127; see also Robert C. Clark, The Interdisciplinary Study of Legal Evolution, 90 YALE L.J. 1238, 1250-54 (1981) (describing evolution of modern reorganization statutes from collective liquidation procedures and equity receiverships).

${ }^{74}$ Hybrid outcomes are also not uncommon. A capital structure for a reorganizing entity may include new investors as well as prepetition creditors. An outside acquirer could basically buy the business via reorganization. Instead of an outright purchase of the assets, the acquirer might make a capital contribution to the reorganizing debtor in exchange for some or all of the reorganizing debtor's shares of common stock issued under the plan.

${ }^{75}$ This sale and distribution typically occurs as part of a liquidating plan in Chapter 11. Distribution of the proceeds occurs upon confirmation of the plan. See infra note 206 and accompanying text.

${ }^{76}$ See infra Part IV(A).
} 


\section{FUTURE CLAIMS IN REORGANZATION}

Proper treatment of future claims is an unsettled question in both internal and external reorganization. In mass tort reorganizations, where the sheer magnitude of future claims liability threatens the survival of a large company, future claims have been included in the bankruptcy proceedings. ${ }^{77}$ However, outside of that context, future claims are generally ignored. ${ }^{78}$ Structuring bankruptcy mechanisms to address the rights of future claimants may be expensive relative to the amounts at stake. ${ }^{79}$ And even if future claimants are legally entitled to be included as creditors in bankruptcy —an issue that is unclear under current law-at the time of bankruptcy, they are largely unaware of their rights and are not in a position to assert them.

Bankruptcy theorists agree, without focusing specifically on external reorganization, that future claims may be handled in bankruptcy. ${ }^{80}$ However, they disagree as to whether future claims must always be included ${ }^{81}$ or whether their inclusion should depend on the discretion of plan proponents ${ }^{82}$ - typically, the debtors. Under this latter "flexible approach," future claims excluded from the process would simply retain their nonbankruptcy rights. ${ }^{83}$ While including future claims in

77 See infra Part III(C)(1).

${ }^{78}$ See, e.g., Western Auto Supply Co. v. Savage Arms, Inc. (In re Savage Indus., Inc.), 43 F.3d 714 (1st Cir. 1994) (bankruptcy sale of firearms manufacturer that made no provision for future claims); Fairchild Aircraft Inc. v. Cambell (In re Fairchild Aircraft Corp.), 184 B.R. 910 (Bankr. W.D. Tex. 1995) (bankruptcy sale of aircraft manufacturer with no provision for future claims in liquidating plan) vacated, 220 B.R. 909 (Bankr. W.D. Tex. 1998); see also Jeffrey Davis, Cramming Down Future Claims in Bankruptcy: Fairness, Bankruptcy Policy, Due Process, and the Lessons of the Piper Reorganization, 70 AM. BANKR. L.J. 329, 337 (1996) (noting that prior to appearance of future claimants to assert their rights, "the threat of future claimants had never seemed significant to warrant much attention by the reorganizing parties"). But see Conway v. White Trucks, 885 F.2d 90,91 (3d Cir. 1989) (describing provision for future claims in reorganization plan).

${ }^{79}$ For example, appointment of a special representative may be necessary in order to accord due process to future claimants. See infra Part III(C)(1).

${ }^{80}$ See, e.g., Baird, The Uneasy Case, supra note 5, at 145-46; Carlson, supra note 31, at 145; Heidt, Changing Paradigm, supra note 11, at 1078; Thomas H. Jackson, Translating Assets and Liabilities to the Bankruptcy Forum, 14 J. LEGAL STUD. 73, 96 (1985) [hereinafter Jackson, Translating Assets and Liabilities]; Keating, supra note 58, at 1097; Ralph R. Mabey \& Peter A. Zisser, Improving Treatment of Future Claims: The Unfinished Business Left by the Manville Amendments, 69 AM. BANKR. L.J. 487, 488 (1995) (asserting that bankruptcy court is the "best forum" for mass tort future claims cases); see also REFORMING THE BANKRUPTCY CODE: THE NATIONAL BANKRUPTCY CONFERENCE'S CODE REVIEW PROJECT, FINAL REPORT 33-43 (rev. ed. 1997) [hereinafter NBC FINAL REPORT] (describing proposed treatment of future claims in Chapter 11); 1 REPORT OF THE NATIONAL BANKRUPTCY REVIEW COMMISSION 322-23 (1997) [hereinafter NBRC REPORT] (same).

${ }^{81}$ See infra note 90 and accompanying text.

${ }^{82}$ See NBC FINAL REPORT, supra note 80, at 37-38; NBRC REPORT, supra note 80, at 323; Davis, supra note 78 , at 361 . For a description of these three reform proposals adopting the flexible approach, see infra note 93.

${ }^{83}$ This point is not made explicit in the NBC FINAL REPORT. However, the report does note the unfairness of insulating the reorganized concern from future claims without providing for 
reorganization comports with fundamental bankruptcy policies, a flexible approach avoids having to incur the costs of addressing future claims in those cases where it would not be cost-effective.

A flexible approach may be unobjectionable in some bankruptcy contexts. However, I argue that in external reorganization, a flexible approach merely enables exploitation of future claimants. If their inclusion is optional, external reorganization becomes one more device by which an acquirer and residual claimants-here, current creditors-conspire to leave disproportionate losses with future claimants.

My prescription for proper treatment of future claims in external reorganization has two components. First, future claims should always be included in the bankruptcy proceeding and receive equal treatment with the debtor's other creditors. Second, as an incident to inclusion of future claims, successor liability should be enjoined. This Part discusses the first aspect of my prescription, as part of the larger question of treatment of future claims in reorganization generally. I leave the discussion of successor liability to the next Part.

This Part begins by first explaining the conceptual basis for comprehensive inclusion of future claims, and then introducing the flexible approach. Next, I contrast the mass tort bankruptcies with the ordinary cases, illustrating the transaction costs of addressing future claims and the courts' struggle to align conceptual clarity with practical cost consequences. Finally, I focus on external reorganization. I distinguish it from internal reorganization-the model more commonly conceived as "reorganization"--based on the differing consequences to future claimants of their exclusion from the proceedings. I explain future claimants' more precarious position if excluded from external reorganization. I assert that a flexible approach in external reorganization fails to respect future claimants' rights as creditors, but merely enables subversion of such rights.

\section{A. Including Future Claims}

It is a relatively uncontroversial proposition among bankruptcy scholars that the bankruptcy system, if called upon, should be capable of addressing future claims. ${ }^{84}$ Dealing with future claims is consistent with fundamental bankruptcy goals.

their payment. See NBC FINAL REPORT, supra note 80, at 36; see also Davis, supra note 78, at 363 (stating that future claims ignored in bankruptcy must be "left unaffected").

${ }^{84}$ Whether the bankruptcy system is the ideal or best place to handle future claims is subject to some debate. Compare Coffee, Class Wars, supra note 2, at 1457-61 (finding bankruptcy reorganization superior to class action for resolving mass torts while protecting interests of future claimants), and Mabey \& Zisser, supra note 80, with Edith H. Jones, Rough Justice in Mass Future Claims: Should Bankruptcy Courts Direct Tort Reform?, 76 TEX. L. REV. 1695 
Bankruptcy provides a clear demarcation between the debtor's past and future. It marks a day of reckoning among the debtor and all its obligees-including future claimants, as to whom the debtor's liability-creating conduct has already occurred and can not be unwound. Including future claims allows the debtor to make a clean break with its past, while also allowing victims of the debtor's past mistakes to share in the value available at the time of bankruptcy. Judge Easterbrook describes this concept quite aptly:

Bankruptcy separates the past and future of an enterprise, satisfying claims attributable to yesterday's activities out of existing assets and thereby enabling business operations that have positive value to carry on, unburdened by the sunk costs of blunders that are beyond recall. By letting bygones be bygone, from the firm's perspective, while assuring some compensation to those who learn in the future that these bygones caused them injury, a plan of reorganization ... promotes both productivity and compensation. Failing to satisfy, out of assets available at the time of the petition, the claims of persons whose injury becomes manifest after the filing of the petition, would simultaneously provide (other) creditors with excessively large shares of the estate, and create a drag on ongoing operations that could cause the dissolution of business ventures with positive cash flow (and thus potentially substantial social and private value). ${ }^{85}$

Inability to include future claims in bankruptcy's collective settlement would tend to frustrate bankruptcy goals. Having to answer for past mistakes outside of the collective proceeding would cause a diversion of the reorganized debtor's cash and other resources, and might ultimately imperil survival of the business. ${ }^{86}$ Assuming the

(1998) (criticizing National Bankruptcy Review Commission proposal and bankruptcy approach generally, questioning whether bankruptcy approach is truly an improvement over class action approach). ted).

${ }^{85}$ In re UNR Indus. Inc., 20 F.3d 766, 771 (7th Cir. 1994) (Easterbrook, J.) (citations omit-

A collective process that commences well before the damages or injuries develop might be the only opportunity for future claimants to receive any compensation, both because otherwise early claimants may take all the assets of the company or the company's extraordinary potential liability will dry up access to all capital needed for ongoing business operations.

NBRC REPORT, supra note 80, at 315; see also Baird, The Uneasy Case, supra note 5, at 145-46 (stating that when future tort victims' claims exceed firm's net worth, sale of business to third party must be free of future tort liability in order to preserve going concern and maximize sale proceeds, with tort victims sharing in sale proceeds); Heidt, Changing Paradigm, supra note 11, at 1084 (arguing that failing to free debtor from consequences of prebankruptcy acts would 
business is worth more alive than dead, saving the going concern also maximizes recoveries for creditors, including future claimants. Even if future claims liability were not significant enough to threaten the viability of the post-reorganization going concern, the continuing specter of liability might hamper operations. This would depress the value of the reorganized debtor, and creditors' bankruptcy distributions would be diminished accordingly.

Failure to include future claims would also result in differential treatment among the debtor's various obligees. In particular, it would mean differing treatment as between current and future tort victims, and among future tort victims inter se. ${ }^{87}$ All are injured by the identical prebankruptcy conduct of the debtor but would receive differing treatment based on the serendipity of the timing of their respective injuries and the vagaries of state law.

The current tort victim receives her ratable share of the common pool along with other unsecured creditors. The excluded future tort victim must pursue her nonbankruptcy rights. If the debtor reorganizes internally, then the future tort victim may recover in full. Her legal rights can not be affected by a proceeding from which she was excluded. $^{88}$ If the debtor instead reorganizes externally-that is, sells the business-the future claimant is placed in an all-or-nothing position. The debtor will have distributed its assets and disappeared by the time of the future claimant's injury. If she is lucky, successor liability is available in her state, and she may recover in full from the acquirer. If unlucky, she receives nothing. ${ }^{89}$

jeopardize reorganization); Keating, supra note 58, at 1099 (noting that bankruptcy's solution to collective action problem preserves going concern value of firm whose survival is threatened by future claims); Roe, Mass Tort, supra note 2.

87 "Fundamental principles of justice require that a person who develops asbestosis 40 years after exposure should have the same entitlement to compensation as a person who got asbestosis 25 years earlier from the same exposure." NBRC REPORT, supra note 80, at 318 ; see also Heidt, Changing Paradigm, supra note 11, at 1084 (describing unequal treatment if future claims are not included); Smith, supra note 8, at 378-82 (arguing that risk averse tort victims would choose rule of equal treatment among themselves in Rawlsian hypothetical bargain). But see Roe, Mass Tort, supra note 2, at 855 (denying applicability of hypothetical bargain rationale to involuntary tort claimants and asserting that "temporal equality in compensation cannot be unambiguously derived from fairness principles").

I argue below that in the external reorganization context, future claimants should receive equal treatment not only with each other and current tort claimants, but with current claimants generally. See infra Part III(D)(4).

${ }_{88}^{88}$ See infra note 145 and accompanying text.

${ }^{89}$ In general, exclusion from bankruptcy's common pool is undesirable from the future claimant's perspective. If excluded, a future claimant will recover when (1) a going concern is internally reorganized or (2) the going concern is sold and the future claimant enjoys successor liability rights against the acquirer. As a practical matter, however, most going concerns will not survive bankruptcy but will eventually be liquidated piecemeal, which does not produce any entity to sue. And as to those going concerns sold through external reorganization, successor products liability is hit-or-miss. See supra Part I(B). Exclusion of future claimants from bank- 


\section{B. Mandatory Inclusion Versus Flexibility}

A solid conceptual foundation exists, then, for treating future claims in bankruptcy. Because inclusion of future claims accords with basic bankruptcy norms, some commentators advocate mandatory inclusion as the only defensible approach. ${ }^{90}$ For the most part, however, they fail to consider the transaction costs that such a rule may generate, or the effect of such costs on reorganization. ${ }^{91}$ Its implementation may be problematic in many cases. As Professor Davis

ruptcy may therefore leave them with no recovery whatsoever. See DougLAS G. BAIRD, THE ELEMENTS OF BANKRUPTCY 90-91 (rev. ed. 1993) (describing future claimant's different prospects depending on whether debtor is liquidating or reorganizing); Jackson, Translating Assets and Liabilities, supra note 80, at 95-96 (stating that unascertained tort claimants may be better off without successor liability in bankruptcy if as a consequence of its application, such tort claimants would be left out of the process, while other creditors controlling asset disposition push for piecemeal liquidation, leaving unascertained claimants with nothing).

${ }^{90}$ To be sure, theorists emphasize different aspects of bankruptcy's multifarious goals in their analyses. Some emphasize the fundamental separation of the debtor's past from its future. See Jackson, Translating Assets and Liabilities, supra note 80, at 82 (stating that future claims based on debtor's past acts that are cognizable under state law and have some value at time of bankruptcy should be treated as prebankruptcy claims).

If the debtor were to cease doing business on the filing of the bankruptcy petition, it would not influence the likelihood that [asbestos] claimants would eventually exhibit the signs of an asbestos-related disease attributable to the debtor's product. The company's future survival is irrelevant to whether or not the disease or injury manifests itself.

Id.

Others focus as well on the related purpose of debtor rehabilitation. They reason-either implicitly or explicitly - that because future claims must be included in some cases in order to assure a successful reorganization, then for consistency's sake, they should count as prebankruptcy "claims" to be dealt with in all cases. See Baird, The Uneasy Case, supra note 5, at $145-46$ (using going concern sale example to show that survival of business may depend on treating future claims in bankruptcy); Heidt, Changing Paradigm, supra note 11, at 1084 (asserting that comprehensive inclusion is required to assure successful reorganization); Keating, supra note 58, at 1098-99 (arguing that only conduct test-which holds that a bankruptcy claim exists if the debtor's prebankruptcy conduct will ultimately give rise to the claim-works in solving state law collective action problem, and that inclusion should not depend on the projected magnitude of future claims liability); Roe, Mass Tort, supra note 2 (arguing for inclusion of future claims in mass tort context but refraining from prescribing any distributional norm).

Still others emphasize an equal treatment rationale. See supra note 87 and accompanying text. While Professor Smith focuses on the mass tort context, his equal treatment analysis implies that future claims should be included in other bankruptcy contexts as well and receive equal treatment with current tort victims. See Smith, supra note 8, at 401-09. The NBRC proposal explicitly adopts an equal treatment rationale as a basis for including future claims. See NBRC REPORT, supra note 80 at 318 (discussing equal treatment with current tort claims); id. at 321 (discussing equal treatment with current claims in liquidation). Ironically, at the same time, the proposal limits its equal treatment prescription to the mass liability situation. See id. at 322 . For further discussion of the applicability of the equal treatment norm, see infra Part III(D)(4).

${ }^{91}$ One exception is Professor Keating, who has identified the due process and estimation problems with an approach requiring comprehensive inclusion of future claims. He suggests that the insurance market may be available to ameliorate some of these problems. See Keating, supra note 58 , at $1100-02$. 
points out, mandatory inclusion "would place an undue and frequently unworkable burden on all reorganizations.",92

The flexible approach ${ }^{93}$ is more pragmatic as it enables consideration of such costs. Proposals for a flexible approach are premised on the idea that reorganization should afford some mechanism by which final disposition of future claims may be accomplished, and that resort to such a mechanism requires appropriate treatment for future claims, ${ }^{94}$ but that resort to the mechanism should be at the option of

\footnotetext{
${ }^{92}$ Davis, supra note 78 , at 366.
}

[U]nless a fund of significant size is created, there is a danger it will eat itself up in administrative costs before paying out to future claims .... Furthermore, the cost of appointing a representative and paying that representative to investigate and participate in the valuation of future claims and the design of a fund will be significant. To impose these costs on every reorganization would make little sense, especially because future claims, while always a possibility, are rarely a significant problem for most businesses.

Id; see also NBRC REPORT, supra note 80, at 332 (noting question of cost-efficiency in requiring appointment of future claims representative in every case disposing of mass future claims).

${ }^{93}$ Three separate reform proposals adopt this general approach. The National Bankruptcy Conference proposes that future claims be cognizable in bankruptcy, but that the Chapter 11 plan proponent-typically the debtor-be entitled to decide whether to include future claims. See NBC FINAL REPORT, supra note 80, at 37-38.

The National Bankruptcy Review Commission proposes to include future claims in the mass liability context, but specifically declines to address future claims outside that context. Even in a mass liability situation, future claims are not assured of being included. They qualify for inclusion as "mass future claims" if "the debtor has been subject to numerous demands for payment for injuries or damages" arising from liability-creating prepetition conduct, and "is likely to be subject to substantial future demands for payment on similar grounds." NBRC REPORT, supra note 80 , at 322 . However, whether those conditions obtain will presumably be decided by plan proponents. Moreover, appointment of a future claims representative is required only if (1) the plan attempts to deal with mass future claims or (2) a party in interest petitions for such an appointment. See id. at 329. This arrangement effectively leaves to other parties the decision whether unrepresented future claimants should be included. It probably amounts to a flexible approach in practice.

It might be theoretically possible for future claimants to participate or petition for representation. No future claimant, however, would typically have enough financial incentive to do so. See supra note 10 and accompanying text. It might be possible that bounty-hunting lawyers would serve as watchdogs for the interests of future claimants. See Davis, supra note 78, at 37980 (speculating that class action lawyers will protect future claimants). See generally John C. Coffee, Jr., Understanding the Plaintiff's Attorney: The Implications of Economic Theory for Private Enforcement of Law through Class and Derivative Actions, 86 COLUM. L. REV. 669 (1986) (discussing economic incentives of and constraints on "bounty hunter" plaintiffs' attorneys). That practice, however, has yet to develop in the future claims context, and courts' reaction to such a practice is difficult to predict.

Professor Davis's proposal provides even more flexibility than the preceding two. Not only may future claims be ignored in reorganization, but even after the decision is made to include them and a future claims representative appointed, his proposal allows future claims to be cut out of any bankruptcy distribution as a form of cramdown. See Davis, supra note 78, at 363.

${ }^{94}$ What counts as "appropriate" varies depending on the proposal. All three proposals contemplate appointment of a representative for future claims. See, e.g., NBC FINAL REPORT, supra note 80 , at 37-39. Only the NBRC proposal embraces equal treatment for future claims with current claims. See supra note 90. As noted earlier, while Professor Davis's proposal requires appointment of a future claims representative, if it were decided later in the case that 
the plan proponent. Whether to include future claims would presumably be part of any plan negotiation, with the debtor and current creditors deciding whether the transaction costs were "worth it." Presumably, they would decide to include future claims only if that were necessary to save the going concern. ${ }^{95}$

Not surprisingly, the National Bankruptcy Conference and the National Bankruptcy Review Commission-whose numbers include not only academics but also prominent judges and practitioners, who must deal with the real world consequences of future claims in bankruptcy-favor flexibility in handling future claims. ${ }^{96}$ It should also not surprise that the courts have been less than uniform in their treatment of and analyses concerning future claims.

\section{Current Practice: Costs Versus Conceptual Clarity}

The question of treating future claims in bankruptcy first became an issue with the mass tort bankruptcies. ${ }^{97}$ These cases provided the original context in which lawyers, courts and theorists worked out the theory and practice concerning future claims in bankruptcy. From these cases has emerged a now "traditional" model for addressing future claims. This section first describes the basic concept and structure of this traditional approach and the mass tort setting in which it developed.

The model solution is not costless, however. A large case can support it. But courts in other cases, with only this ready model from which to work, have struggled in attempting to reconcile conceptual

future claims should be ignored after all, his proposal would allow their exclusion. See supra note 93 .

${ }^{95}$ See Davis, supra note 78, at 361 ("Businesses differ. Sometimes the reorganization will best be facilitated by bringing future claims into the plan, and sometimes the reverse will be true."). But see infra Part III(D) (discussing less benign motivations in the external reorganization context).

${ }^{96}$ Indeed, the need for flexibility may have been so self-evident within the National Bankruptcy Conference that its report describes this aspect of its proposal in two sentences, with no express justification or even commentary. See NBC FINAL REPORT, supra note 80, at 37 ("[T] he plan proponent (most frequently, the debtor) or the trustee in a chapter 7 case must identify the liability it wishes to deal with as a future claim .... This permits the proponent, not the potential claimants, to decide initially whether to [include future claims]."). Judge Mabey's article outlining the original NBC proposal likewise makes no mention of the debtor's discretion built into the proposal. See Mabey \& Zisser, supra note 80, at 503.

${ }_{97}$ See NBRC REPORT, supra note 80, at 322 (explaining report's exclusive focus on mass liability cases because they are "the most pressing and most complex cases, where the claims ... are so massive that they warrant special procedures and protections"); Harvey J. Kesner, Future Asbestos Related Litigants as Holders of Statutory Claims Under Chapter 11 of the Bankruptcy Code and Their Place in the Johns-Manville Reorganization (pts. 1 \& 2), 62 AM. BANKR. L.J. 69, 159 (1988) (discussing treatment of future asbestos claims); Roe, Mass Tort, supra note 2 (describing treatment of mass tort claims in bankruptcy); Smith, supra note 8; see also Heidt, Changing Paradigm, supra note 11, at 1061-62 (describing "extraordinary liabilities" of mass tort and environmental obligations). 
clarity with scarcity of resources. This section next sketches the courts' struggle with the different types of cases and the doctrinal messiness that has emerged.

\section{The "Traditional" Approach in the Mass Tort Context}

A mass tort case involves a large company that has mass manufactured a product that later proves to be harmful. The company resorts to bankruptcy in order to deal with the ensuing "enterprisethreatening massive liabilities." 98 Such a company finds itself in dire financial straits, not necessarily because it is short of cash and has trouble meeting current expenses. Instead, its primary concern is future products liability. The full financial impact of the harmful product may not necessarily have hit the manufacturer's financial statements yet, but past experience makes clear that over time, more and more victims will sustain injuries and will sue. There is little doubt that the aggregate liabilities will ultimately be staggering. Ignoring these future tort liabilities would mean the eventual operational collapse of the manufacturer. ${ }^{99}$

The case presents the daunting task of structuring mechanisms to assure fair and adequate compensation to future tort victims consistent with due process, while at the same time preserving the going concern value of the tortfeasing company, upon which future claimants may depend for their future compensation. The identities of many or most future claimants and the extent of their injuries or other harm may not be known at the time of bankruptcy. ${ }^{100}$ The basic

\footnotetext{
${ }^{98}$ NBRC REPORT, supra note 80 , at 327.

${ }^{99}$ As the cloud of future liability becomes darker and darker, financing would be more and more difficult to obtain. Doubts about the continuing viability of the business would grow. Customers and suppliers would defect. Rather than wait for this slow death to overtake the business, the firm actively seeks a global solution to the overhanging future liabilities. Bankruptcy is an attractive option. See Roe, Mass Tort, supra note 2, at 856-62 (describing slow process of operational collapse for company beset by mass future tort liabilities that inhibit its access to capital markets).

The other option that has been tried to date is the settlement class action-that is, a class action initiated by the defendant, the manufacturer, for the purpose of settling future claims. The potential for conflicts of interest is of course high, and perhaps fatal. See Amchem Prods. v. Windsor, 117 S. Ct. 2231 (1997) (affirming denial of certification to proposed settlement class); Coffee, Class Wars, supra note 2 (discussing problems associated with mass tort class actions); Coffee, The Corruption of the Class Action, supra note 2, at 853 (arguing that "the critical problem with settlement class actions is that they permit the defendants to choose the plaintiffs' attorney").

${ }^{100}$ For example, exposure to asbestos may lead to emphysema, mesothelioma, and lung cancer. However, it would be impossible to identify or locate every person ever exposed to asbestos, given the popularity of its use as an insulating material from the 1950s to the 1970s. See Coffee, Class Wars, supra note 2, at 1430 (noting that "virtually every U.S. citizen has been exposed to asbestos"). In addition, not every person exposed to the substance will manifest ill effects. The degree of exposure and other environmental factors will matter.
} 
problem for the debtor manufacturer is to fix or at least cap the aggregate amount of contingent liability, and then to set aside or arrange for some fixed pool of assets that will be used to pay future claims as they arise.

A "traditional" model emerged to resolve these issues. It has several novel components. ${ }^{101}$ To address notice and other due process problems, the debtor obtains appointment of a special legal representative for future claimants, who typically can not represent themselves. ${ }^{102}$ Complex estimation proceedings are conducted in order to value future claims and fix the manufacturer's aggregate liability. ${ }^{103}$ A claims resolution facility is structured to streamline claims liquidation and disburse payments as future claims mature. ${ }^{104} \mathrm{~A}$ trust device

With a product like intrauterine devices (A.H. Robins) or breast implants (Dow Corning), identification of potential tort claimants may be less problematic. Potential victims of those products could more readily self-identify in response to widespread publication notice. Some could conceivably be identified through medical records. The difference is really one of degree. Even if future claimants could self-identify, though, there remains the problem of getting healthy future claimants to appreciate the significance of legal proceedings that will only matter to them in the event of future manifestation of injury. See supra note 10 and accompanying text.

101 This model was also followed in at least one case not involving a mass tort situationthat is, where future tort claims were not the primary factor precipitating bankruptcy. In the external reorganization of Piper Aircraft, a legal representative was appointed, future claims were dealt with in the liquidating plan via a trust fund device, and a channeling injunction was issued in connection with the plan confirmation. See Piper Disclosure Statement, supra note 12, at 26. While future claims liability was an important concern in the case, poor management was apparently at least as significant a cause of the company's demise. See id. at 11-12 (describing "devastating consequences" of key business decisions of prepetition management).

${ }^{102}$ See, e.g., In re Amatex Corp., 755 F.2d 1034 (3d Cir. 1985) (appointing representative for asbestos-exposed future claimants, who are parties in interest); In re Johns-Manville Corp., 36 B.R. 743 (Bankr. S.D.N.Y. 1984) (same). Some courts, however, refused to appoint future claims representatives. See, e.g., Locks v. United States Trustee, 157 B.R. 89 (Bankr. W.D. Pa. 1993) (discussed infra note 111).

${ }^{103}$ See, e.g., In re Eagle-Picher Indus., 189 B.R. 681 (Bankr. N.D. Ohio 1995) (estimating both prepetition and future asbestos claims for distribution purposes); see also In re Dow Corning Corp., 211 B.R. 545 (Bankr. E.D. Mich 1997) (discussing merits of competing estimation proposals).

While the Code specifically contemplates court estimation of contingent or unliquidated claims, estimation is specifically authorized only for purposes of allowance, see 11 U.S.C. $\S$ 502(c) (1994), and voting, see FED. R. BANKR. P. § 3018(a) (authorizing court to allow claim temporarily "in an amount which the court deems proper" for voting purposes). Claim allowance determines which claims may validly participate in the case. Only claims that are "allowed" are entitled to vote on the terms of reorganization, see 11 U.S.C. $\$ 1126$, and receive distributions, see id. $\$ 726$.

Estimation for purposes of distribution is not specifically authorized in the Code or the Bankruptcy Rules. Both the National Bankruptcy Conference and the National Bankruptcy Review Commission have recommended statutory amendments clarifying that courts may estimate claims for purposes of distribution. The NBRC proposal, however, is limited to mass future claims. See NBC FINAL REPORT, supra note 80, at 39; NBRC REPORT, supra note 80, at 341.

${ }^{104}$ In Piper, the claim resolution process included mandatory pre-trial mediation, as well as a binding arbitration alternative to litigation. See Piper Disclosure Statement, supra note 12, at 138-39. 
is employed to manage the assets that will be the source of such payments. ${ }^{105}$ A "channeling injunction" enjoins future claimants from pursuing the reorganized debtor or any successor to the debtor's business or assets. Future claims are instead channeled to the designated payment trust, and the going concern is insulated from postbankruptcy suit by future claimants. ${ }^{106}$

The costs of this traditional approach have run into the tens of millions of dollars. ${ }^{107}$ However, given the size of the debtors, the sheer numbers of future claimants and other creditors, and the staggering amounts of liability, one might expect that comprehen-

The Claims Resolution Facility created by the Robins plan-while not necessarily ideal in its implementation, see SOBOL, supra note 10, at 309-25 (providing scathing appraisal of judge's manipulation of supposedly independent claims resolution facility and associated trust)-provides an interesting framework of procedural choices. It offers several different claim processing options, ranging from a "short form," which pays the electing claimant a nominal amount upon a minimal showing of Dalkon Shield use and injury, to a fairly elaborate settlement process involving in-depth review of the claim, including the electing claimant's medical records. Should the process fail to produce a settlement, the claimant may resort to binding arbitration or trial. See Sixth Amended and Restated Disclosure Statement Pursuant to Section 1125 of the Bankruptcy Code, In re A.H. Robins Co. (Bankr. E.D. Va. March 28, 1998) (No. 85-01307-R), at CRF 1-9 [hereinafter Robins Disclosure Statement]; see also Mark A. Peterson, Giving Away Money: Comparative Comments on Claims Resolution Facilities, LAW \& CONTEMP. PROBS., Autumn 1990, at 113, 113-36 (1990) (comparing differing features and objectives of several claims resolution facilities).

${ }^{105}$ See, e.g., In re Joint E. and S. Dist. Asbestos Lit. (In re Johns-Manville Corp.), 982 F.2d 721 (2d Cir. 1992) (describing plight of Manville Trust), modified, 993 F.2d 7 (2d Cir. 1993). See generally Roe, Mass Tort, supra note 2, at 864-92 (describing payment devices to manage uncertainty regarding aggregate claims liability).

${ }^{106}$ See, e.g., In re A.H. Robins Co., 88 B.R. 742 (E.D. Va. 1988) (enjoining suit against successor corporation, among others), aff'd sub nom. Menard-Sanford v. Mabey (In re A.H. Robins Co.), 880 F.2d 694 (4th Cir. 1989); In re Johns-Manville Corp., 68 B.R. 618, 625 (Bankr. S.D.N.Y. 1986) (holding that bankruptcy court has equitable power to issue channeling injunction), aff'd sub nom. Kane v. Johns-Manville Corp., 843 F.2d 636 (2d Cir. 1988); Piper Disclosure Statement, supra note 12, at 112 (describing channeling injunction). Of these three cases, only Piper involved an asset sale. Manville was internally reorganized, and the channeling injunction was used to insulate the reorganized debtor and others from suit by future claimants. See Johns-Manville, 68 B.R. at 624. In A.H. Robins, the debtor was merged into another entity as part of the plan. That surviving entity and others were the beneficiaries of the channeling injunction. See A.H. Robins, 88 B.R. at 751.

${ }_{107}$ See Findley v. Blinken (In re Joint Eastern and Southern Dists. Asbestos Litig.), 129 B.R. 710,750 (E. \& S.D.N.Y. 1991), vacated, 982 F.2d 721 (2d Cir. 1992), modified, 993 F.2d 7 (2d Cir. 1993) (describing costly process of resolving asbestos claims in several cases, and noting specifically that "[t]he Manville Trust, designed to fairly and expeditiously compensate personal injury claimants was spending approximately one million dollars a week on outside counsel litigation defense costs alone in 1990 in addition to its own staff counsel and overhead costs at a time when it had almost no unrestricted cash"); Francis E. McGovern, Resolving Mature Mass Tort Litigation, 69 B.U. L. REV. 659, 686 (1989) (describing the claims estimation process in the A. H. Robins bankruptcy as "the largest and most expensive social science survey ever conducted under the auspices of a court" and noting that the data collection process alone cost five million dollars); Trust Officials Report Surge in Claim Filings in 1994, MEALEY's LITIGATION REPORT: ASBESTOS, March 17, 1995, at 1 (reporting that for 1994, Manville Trust operating expenses totaled $\$ 8.1$ million, and total expenses were approximately $\$ 14.7$ million). 
sive resolution would not come cheap. ${ }^{108}$ Moreover, the large stakes involved suggest both the far-reaching consequences of operational collapse and that avoiding such consequences may be worth a significant investment. ${ }^{109}$ Given these stakes, innovative solutions are possible that might be cost-prohibitive in other circumstances. ${ }^{110}$

\section{Pragmatism with Future Claims}

Future claims in the run-of-the-mill case raise the same conceptual difficulties as in the mass tort context. However, for small and medium-sized companies, the economics are quite different,

${ }^{108}$ But cf. John A. Siliciano, Mass Torts and the Rhetoric of Crisis, 80 CORNELL L. REV. 990, 1000-05 (1995) (questioning claims that transaction costs for mass torts are "too high").

${ }^{109}$ Whether debtor rehabilitation should be a goal of Chapter 11 is the subject of some debate. See Baird \& Jackson, supra note 55, at 100 (suggesting that core purpose of bankruptcy law should be to solve collective action problem among creditors). However, that rehabilitation currently is a goal can not be gainsaid.

110 The legal basis for this overall approach is not free from doubt. See NBC FINAL REPORT, supra note 80 , at 34 , and NBRC REPORT, supra note 80 , at 315 , which describe the current legal uncertainty relating to this "traditional" model for treating future claims in the mass liability context, as well as legislative proposals to address this uncertainty. In the mass tort asbestos cases, even Congress was solicited to provide specific benediction. See 11 U.S.C. $\S 524(\mathrm{~g})(1994)$ (authorizing, both retroactively and prospectively, issuance of channeling injunction in asbestos case, provided, inter alia, that trust is created to pay future claims).

Actual results to date have also not been without controversy. These schemes have sometimes been subverted in the implementation-largely in the valuing or allowance of future claims-in order to guarantee survival of the going concern and more than nominal returns to equity holders, which of course comes at future claimants' expense. See, e.g., In re Dow Coming Corp., 211 B.R. 545, 599 \& n.56 (Bankr. E.D. Mich. 1997) ("The failure of the traditional model, which was first crafted in Johns-Manville, is widely recognized."); Findley v. Blinken (In re Joint Eastern and Southern Dists. Asbestos Litig.), 129 B.R. 710, 754-62 (E. \& S.D.N.Y. 1991), vacated, 982 F.2d 721 (2d Cir. 1992), modified, 993 F.2d 7 (2d Cir. 1993) (describing problem of massive underfunding of Manville Trust); SOBOL, supra note 10, at 309-25 (describing judge's manipulation of purportedly independent Claimants Trust in order to assure "accuracy" of court's prior estimate in A.H. Robins bankruptcy); Mabey \& Zisser, supra note 80 , at 495-96 (explaining favoritism of current claims over future claims in structuring of Manville Trust).

Nevertheless, there may be some basis for optimism concerning the traditional model. As Professors Warren and Westbrook aptly note:

[G]iven the novel use of bankruptcy laws to address a massive social problem that

Congress and other institutions refused to address, it could be argued-as Dr. Johnson said of the dog walking on its hind legs-that the wonder was not that it was done badly, but that it was done at all.

WARREN \& WESTBROOK, supra note 57, at 799. Given the value at stake in the large cases, the consequent public scrutiny of their outcomes and the attention of reform proponents aimed at mass future liability issues, we may be hopeful that legal clarity will evolve and that implementation of the model will improve. For examples of innovative approaches, see Smith, supra note 8 (describing use of capital markets as solution to problems of estimation and distribution with respect to future claims); Dow Corning, 211 B.R. at 601-03 (describing Professor Smith's capital markets approach and urging its consideration by the parties); and Michael J. Saks \& Peter David Blanck, Justice Improved: The Unrecognized Benefits of Aggregation and Sampling in the Trial of Mass Torts, 44 STAN. L. REV. 815 (1992) (arguing that aggregation and sampling produces more precise and reliable outcomes than individualized bilateral trials). 
and future tort liabilities may not necessarily be the central issue in bankruptcy. In this context, administration of future claims may be prohibitively expensive. Even if there is going concern value and it is successfully salvaged, resort to the traditional model would likely generate significant fixed costs disproportionate to the size of the case or any expected benefit to future claimants. ${ }^{111}$

On the other hand, no alternative approach seems to have developed. Given the smaller stakes and fewer resources involved, and the possibly incidental nature of the future claims liability, ignoring future claims may be a tempting alternative to dealing with them. The immediate pressures to rehabilitate the business, save jobs, and preserve firm-specific capital like customer and supplier relationships, ${ }^{112}$ all conspire to overwhelm any attempt at fair and equitable treatment of faceless, nameless future tort victims. As previously discussed, this often happens in practice. ${ }^{113}$

\section{a. "Creditors" and "Claims": The Statutory Issue}

Courts have wrestled over the fundamental question whether or not future claimants qualify as "creditors" that can be dealt with in bankruptcy. Consistent with the notion of separating the debtor's past from its future, only if their claims "arise" before bankruptcy may future claimants be considered creditors. ${ }^{114}$ And a close

${ }^{111}$ Even for a large debtor, which may be able to bear significant administrative expenses, whether a viable going concem can be salvaged may not be clear at the outset of the case. If piecemeal liquidation turns out to be the result-and any optimism concerning any going concern value turns out to have been unfounded-then an inordinate amount of scant liquidation proceeds may be consumed by the administrative costs of including future claims, leaving only a relatively small residue for actual distribution to current and future claimants. For example, in Locks v. United States Trustee, 157 B.R. 89 (W.D. Pa. 1993), the court refused to appoint a legal representative for future claims because the debtor was liquidating. Since there would be no business left to save from overhanging future claims liability, the court was unwilling to recognize future claimants as creditors, citing among other reasons the administrative costs of maintaining a facility to pay future claims and the minimal dividend they would receive. Future claims received no consideration. See id. at 99 . But see $\ln$ re Forty-Eight Insulations, Inc., 58 B.R. 476 (Bankr. N.D. Il. 1986), in which the court appointed a future claims representative even though the debtor was liquidating. " $[1] \mathrm{t}$ would be highly inequitable to distribute the liquidated assets of the debtor to the currently known plaintiffs to the detriment of the potential claimants merely because the potential claimants have not yet manifested an injury." Id. at 477 .

${ }^{112}$ See generally Oliver E. Williamson, Transaction-Cost Economics: The Governance of Contractual Relations, 22 J.L. \& ECON. 233, 238-45 (1979) (describing transaction-specific investment in contractual relations).

${ }_{113}$ See supra note 78 and accompanying text.

${ }^{114}$ A creditor is an "entity that has a claim against the debtor that arose at the time of or before the order for relief . . ."11 U.S.C. $\$ 101(10)(A)(1994)$, which for a voluntary petition occurs upon the filing of the petition. See id. $\S 301$. The legislative history makes clear that "'[c]reditor' is defined to include only holders of prepetition claims against the debtor." H.R. REP. NO. 95-595, at 309 (1977) [hereinafter HOUSE REPORT].

Section 101(5) defines "claim" as a 
reading of the Bankruptcy Code ${ }^{115}$ suggests that only creditors are eligible to participate in bankruptcy and share in bankruptcy distributions. ${ }^{116}$ If future claims are deemed not to arise prebankruptcy, then bankruptcy would seem ineffective to address or affect future claimants' rights.

This question is a tricky one. ${ }^{117}$ The definition of "claim" includes contingent and unmatured rights to payment, ${ }^{118}$ and legislative history suggests that Congress intended to be quite inclusive in defining the types of obligations that could be included. ${ }^{119}$ However, courts disagree as to the proper construction of these critical terms.

(A) right to payment, whether or not such right is reduced to judgment, liquidated, unliquidated, fixed, contingent, matured, unmatured, disputed, undisputed, legal, equitable, secured, or unsecured; or

(B) right to an equitable remedy for breach of performance if such breach gives rise to a right to payment, whether or not such right to an equitable remedy is reduced to judgment, fixed, contingent, matured, unmatured, disputed, undisputed, secured, or unsecured.

11 U.S.C. § 101(5).

is 11 U.S.C. $\S \S 101-1330$ (1994). The Bankruptcy Code may be referred to herein as the "Code." Uniess otherwise indicated, all subsequent statutory references are to the Bankruptcy Code.

${ }^{116}$ A proof of claim may be filed only by or on behalf of a creditor. See 11 U.S.C. $\$ 501$. The allowance of the claim will be determined as of the petition date. See id. $\$ 502$. Only such allowed claims may share in the bankruptcy distribution and vote on the Chapter 11 plan. See id. $\S \S 726,1126$. The terms of a Chapter 11 plan bind "any creditor," and confirmation of a Chapter 11 reorganization plan discharges only preconfirmation debts. See id. $\S 1141(\mathrm{a})$, (d)(1)(A). In addition, only prepetition claims are subject to the automatic stay. The filing of a bankruptcy petition stays collection efforts only as to claims which "arose before the commencement of the case." Id. § 362(a)(1).

${ }^{117}$ A related issue involves the interim claim, which first becomes apparent during the course of the case. For example, the tort victim using the debtor's defective product manufactured prepetition, who sustains injury after the petition has been filed but before confirmation, has been identified in time to assert a claim in the case. Courts have struggled over the question whether this is a prepetition claim or not, as the automatic stay applies only to a claim which "arose before commencement of the case." 11 U.S.C. \$ 362(a)(1). Compare Grady v. A.H. Robins Co. (In re A.H. Robins Co.), 839 F.2d 198 (4th Cir. 1988) (holding that even though injury from Dalkon Shield arose postpetition, Plaintiffs held prepetition claim subject to stay where tortious acts giving rise to liability were performed prepetition), with Pettibone Corp. v. Ramirez (In re Pettibone Corp.), 90 B.R. 918 (Bankr. N.D. Ill. 1988) (holding that although allegedly defective product was manufactured prepetition, no prepetition relationship existed; therefore, Plaintiff held postpetition claim not subject to stay, though court might consider issuing an injunction staying Plaintiff's suit in reliance on section 105(a)).

As a practical matter, this type of claim should not trouble us much. It does not raise the serious problems of the sort implicated by "true" future claims, i.e., those for which the identity of the claimant or the fact of injury can not be determined until after the bankruptcy has concluded. However, as the cases cited in the preceding paragraph suggest, cases involving interim claims often result in rulings that affect treatment of future claims as well. See also Davis, supra note 78 , at 337 (coining the phrase "interim claim").

118 See supra note 114.

119 "By this broadest possible definition, ... the bill contemplates that all legal obligations of the debtor, no matter how remote or contingent, will be able to be dealt with in the bankruptcy case. It permits the broadest possible relief in the bankruptcy court." HOUSE REPORT, supra note 114, at 309. 
Several different approaches have been discussed for determining when future claims arise. ${ }^{120}$ Of these, the conduct test is probably the most conceptually appealing. Under this test, if the debtor's conduct giving rise to the eventual liability has already occurred by the time the petition is filed, then claims for the future injuries resulting from that pre-petition conduct are deemed pre-bankruptcy claims. ${ }^{121}$

The conduct test is most appealing simply because it effects the separation of the debtor's past from its future and enables comprehensive relief from the debtor's past blunders. ${ }^{122}$ And only a conduct test

${ }^{120}$ See Epstein v. Official Comm. of Unsecured Creditors (In re Piper Aircraft Corp.), 58 F.3d 1573 (11th Cir. 1995) (discussing state law accrual test, conduct test and Piper test), modifying 162 B.R. 619 (Bankr. S.D. Fla. 1994); see also Gregory A. Bibler, The Status of Unaccrued Tort Claims in Chapter 11 Bankruptcy Proceedings, 61 AM. BANKR. L.J. 145 (1987) (arguing for accrued state law claim test); Roe, Mass Tort, supra note 2, at 893-98 (discussing statutory basis for including future claims in reorganization and arguing for such inclusion).

Courts sometimes describe the issue as one of determining whether particular rights qualify as "claims," but a close reading of the statutory definitions suggests that the issue is one of timing - that is, when does a particular claim arise? See Heidt, Changing Paradigm, supra note 11 , at 1059 n.10.

${ }_{121}$ See Grady v. A.H. Robins Co., Inc. (In re A.H. Robins Co., Inc.), 839 F.2d 198 (4th Cir. 1988) (holding that even though injury from Dalkon shield arose postpetition, Plaintiffs held prepetition claim subject to stay where tortious acts giving rise to liability were performed prepetition); Waterman S.S. Corp. v. Aguiar (In re Waterman S.S. Corp.), 141 B.R. 552 (Bankr. S.D.N.Y. 1992) (adopting conduct test in asbestos case), vacated on other grounds, 157 B.R. 220 (S.D.N.Y. 1993).

In addition to the conduct test, other plausible tests have been discussed. The accrued state law claim test is the narrowest. Under this test, a claim is deemed to arise only when a cause of action accrues under state law. See In re M. Frenville Co., 744 F.2d 332 (3d Cir. 1984), cert. denied, 469 U.S. 1160 (1985); Schwinn Cycling \& Fitness, Inc. v. Benonis (In re Schwinn Bicycle Co.), 210 B.R. 747 (Bankr. N.D. Ill. 1997), affd, 217 B.R. 790 (N.D. Ill. 1997). In the product liability context, this would mean that no bankruptcy claim arises until some cognizable harm has occurred. Therefore, future claims would not be included. This narrow approach has been "roundly criticized." Jensen v. California Dep't of Health Servs. (In re Jensen), 127 B.R. 27, 30 (B.A.P. 9 th Cir. 1991), aff'd, 995 F.2d 925 (9th Cir. 1993); In re Transportation Sys. Int'l Inc., 110 B.R. 888, 894 (Bankr. D. Minn. 1990), aff'd sub nom. Lovett v. Honeywell, Inc., 930 F.2d 625 (8th Cir. 1991).

The conduct test is the broadest test. Tests of intermediate breadth have also developed. The Piper test requires not only prepetition conduct but also the existence of some preconfirmation relationship between the debtor and the tort victim. See Epstein v. Official Comm. of Unsecured Creditors (In re Piper Aircraft Corp.), 58 F.3d 1573 (11th Cir. 1995) (holding that only those parties asserting claims based on the debtor's prepetition conduct and having preconfirmation relation with the debtor are deemed to hold bankruptcy claims), modifying 162 B.R. 619 (Bankr. S.D. Fla. 1994). The fair contemplation test requires that the claim be within the "fair contemplation" of the parties at the time of bankruptcy. See California Dep't of Health Servs. v. Jensen (In re Jensen), 995 F.2d 925, 930 (9th Cir. 1993).

${ }_{122}$ See Heidt, Changing Paradigm, supra note 11, at 1084-85 (asserting that only conduct test effects appropriate separation of debtor's past and future); Jackson, Translating Assets and Liabilities, supra note 80 , at 82-83 (stating that future claims based on the debtor's past acts that are cognizable under state law and have some value at time of bankruptcy should be treated as prebankruptcy claims); Keating, supra note 58, at 1098-99 (arguing that only conduct test works in solving state law collective action problem); see also supra note 85 and accompanying text. This test should require relatively specific identification of the particular harm- or obligationcreating conduct that is meant to be addressed. This requirement prevents open-ended discharge 
enables all those affected by the debtor's past blunders to receive equal treatment. ${ }^{123}$ A less inclusive test might not suffice.

This conceptual appeal, however, belies the difficult practical consequences that may result. The conduct test effectively requires a mandatory approach. If prepetition liability-creating conduct is sufficient to confer prebankruptcy "claim" status, then future claims must be dealt with in all bankruptcy cases, regardless of the size of a given case, the reason for the filing, or whether the debtor ultimately reorganizes internally or externally, or liquidates piecemeal. ${ }^{124}$ This seems fair conceptually, but as previously discussed, the transaction costs generated may be prohibitive.

\section{b. Judicial Pragmatism}

Perhaps reflecting the disharmony between conceptual clarity and practical messiness, the courts have handled this issue in resultoriented fashion more or less-that is, include future claims if necessary to save the business, ${ }^{125}$ exclude them if not, ${ }^{126}$ and hedge if unclear. In Amatex, ${ }^{127}$ for example, the court hedged. It proclaimed that whether or not future claims are deemed to arise prebankruptcy, future claimants are at least "parties in interest," if not creditors. There-

of obligations and avoids concomitant due process problem. See NBC FINAL REPORT, supra note 80 , at 37 .

${ }^{123}$ See supra notes $87-89$ and accompanying text.

124 The Code currently provides no flexibility in this regard. Reform proposals adopt variants of the conduct test. See NBC FINAL REPORT, supra note 80, at 35-37 (proposing conductbased test); NBRC REPORT, supra note 80, at 326 (espousing conduct-based test); Davis, supra note 78, at 361-64 (espousing preconfirmation conduct test). These proposals, however, also include provisions that would allow future claims to be excluded despite their status as prebankruptcy claims. See supra note 93.

${ }_{125}$ See Grady v. A.H. Robins Co., Inc. (In re A.H. Robins Co., Inc.), 839 F.2d 198 (4th Cir. 1988); Waterman S.S. Corp. v. Aguiar (In re Waterman S.S. Corp.), 141 B.R. 552 (Bankr. S.D.N.Y. 1992), vacated on other grounds, 157 B.R. 220 (S.D.N.Y. 1993). See also In re UNR Ind., Inc., 725 F.2d 1111, 1118-19 (7th Cir. 1984) (Posner, J.), in which the court questioned the correctness of district judge's view that future asbestosis claimants have no rights in bankruptcy. The appeals court suggested that even if future claims may not qualify as statutory prebankruptcy claims, the lower court's equitable powers "just might be broad enough to enable the court to make provision for" such future claims in the plan of reorganization. Id. at 1119. See generally Roach v. Edge (In re Edge), 60 B.R. 690, 701-05 (Bankr. M.D. Tenn. 1986) (adopting conduct test as basis for holding, in dentist's Chapter 7 case, that automatic stay applied to patient's injury discovered postpetition but caused by debtor-dentist's prepetition negligence).

${ }^{126}$ See, e.g., In re Piper, 162 B.R. 619, 628 (Bankr. S.D. Fla 1994) (rejecting conduct test in part because of debtor's view that the going concern sale could be effected without inclusion of future claims); Locks v. United States Trustee, 157 B.R. 89 (W.D. Pa. 1993); discussion supra note 111. But see Fairchild Aircraft Inc. v. Cambell (In re Fairchild Aircraft Corp.), 184 B.R. 910 (Bankr. W.D. Tex. 1995) (finding, in airplane manufacturer's bankruptcy, that failure to afford notice and due process to future claimants-or any consideration at all in bankruptcy proceeding-requires finding that their claims are not bankruptcy claims and their successor liability rights survive), vacated, 220 B.R. 909 (Bankr. W.D. Tex. 1998).

${ }^{127}$ In re Amatex Corp., 755 F.2d 1034 (3d Cir. 1985). 
fore, appointment of a legal representative in Chapter 11 was justified. ${ }^{128}$

In Piper, ${ }^{129}$ the future claims issue was a moving target. Initially, at the behest of a prospective acquirer, the debtor sought appointment of a future claims representative. ${ }^{130}$ It seemed unlikely that a buyer could be found unless future products liabilities of the extant fleet were addressed in the bankruptcy and successor liability risks eliminated, and formal representation of future claimants was thought necessary to bind future claimants to any plan. ${ }^{131}$ In the order appointing Professor David Epstein as the future claims representative, the court was willing to define a class of future claimants based on the conduct test. ${ }^{132}$ However, the court expressly refused at that point to decide whether that class held prebankruptcy claims under the Code. ${ }^{133}$

Professor Epstein later filed a proof of claim for $\$ 100,000,000$ on behalf of his broad class of future claimants, the estimate of future liability having been gleaned from a study prepared by the debtor's actuary. ${ }^{134}$ The debtor, the Committee and several prospective acquirers objected, however. ${ }^{135}$ By that point, the debtor and Committee believed that a buyer could be found even without addressing future claims. ${ }^{136}$ The court disallowed the proof of claim, holding that not all future claims qualified as prebankruptcy claims. Unwilling to countenance the notion that unidentifiable future tort victims could or should be included in the bankruptcy proceeding, the court rejected

${ }^{128}$ See id. at 1041; see also In re Johns-Manville Corp., 36 B.R. 743 (Bankr. S.D.N.Y. 1984) (same analysis).

${ }^{129}$ Epstein v. Official Comm. of Unsecured Creditors (In re Piper Aircraft Corp.), 58 F.3d 1563 (11th Cir. 1995), aff'g 168 B.R. 434 (Bankr. S.D. Fla. 1994), aff'g sub nom. In re Piper Aircraft Corp., 162 B.R. 619 (Bankr. S.D. Fla. 1994).

${ }^{130}$ The prospective purchaser, Pilatus Aircraft Limited, had signed a letter of intent with the debtor. The letter of intent included a requirement that the debtor seek appointment of a future claims representative so that future claims could be paid off and disposed of. See Piper, 162 B.R. at 621 .

${ }^{131}$ See id. at 622 n.3.

132 The class of Future Claimants was defined to include:

All persons, whether known or unknown, born or unborn, who may, after the date of confirmation of Piper's Chapter 11 plan of reorganization, assert a claim or claims for personal injury, property damages, wrongful death, damages, contribution and/or indemnification, based in whole or in part upon events occurring or arising after the Confirmation Date, including claims based on the law of product liability, against Piper or its successor arising out of or relating to aircraft or parts manufactured and sold, designed, distributed or supported by Piper prior to the Confirmation Date.

Epstein, 58 F.3d at 1575-76.

${ }^{133}$ See id. at 1575.

${ }^{134}$ See Letter from David Epstein, Professor, The University of Alabama School of Law, to Frederick Tung, Associate Professor, University of San Francisco School of Law (Apr. 1, 1998) (on file with author) [hereinafter Epstein Correspondence].

${ }^{135}$ See Piper, 162 B.R. at 622 . Pilatus, the prospective acquirer that had requested appointment of a future claims representative, sided with Professor Epstein. See id. at 623.

${ }^{136}$ See id. at 622 n.3. 
Professor Epstein's proposed conduct test, finding its scope overbroad. $^{137}$

Instead, the court adopted a preconfirmation relationship test. That the liability at issue was based on the debtor's prepetition conduct was not sufficient to create a prebankruptcy claim. In addition, the existence of a preconfirmation relationship between the debtor and claimant was required. ${ }^{138}$ Professor Epstein's proposed class did not qualify. ${ }^{139}$

The conclusion to the case provides a further irony. The liquidating plan that was ultimately confirmed with Professor Epstein's support adopted his broad definition of future claims-implicitly adopting a conduct test-and provided for future claims on a par with current claims. ${ }^{140}$ Professor Epstein's original approach was thus vindicated.

This outcome, however, was not so much a triumph of principle as one of politics. Critical to the consensual resolution of the case ${ }^{141}$ was the enactment by Congress of the General Aviation Revitalization Act of 1994 . $^{142}$ This statute of repose prohibits products liability suits against manufacturers of general aviation aircraft for accidents involving aircraft more than eighteen years old. ${ }^{143}$ The effect of this statute on the Piper bankruptcy was to reduce significantly the debtor's aggregate future claims liability, thereby leaving enough value to satisfy all parties. The law became effective at an opportune moment in the case-while the bankruptcy court's decision disal-

\footnotetext{
${ }^{137}$ See id. at 628-29.

${ }^{138}$ See Epstein, 58 F.3d at 1577. Such a relationship could be based, for example, on contact, exposure, impact or privity. See id. The bankruptcy court had originally required a prepetition relationship but modified this position in Piper v. Calabro (In re Piper Aircraft Corp.), 169 B.R. 766 (Bankr. S.D. Fla. 1994), and the court of appeals affirmed the test as modified. See Epstein, 58 F.3d at 1577-78 \& n.5.

${ }^{139}$ See id at 1577. Of course, some subset of Professor Epstein's proposed class would have qualified under the court's test. But the class itself, structured as it was around the conduct test, was defined too broadly for the court's liking.

${ }^{140}$ See Piper Disclosure Statement, supra note 12, at 53.

${ }^{141}$ See Epstein Correspondence, supra note 134.

${ }_{142}$ Pub. L. No. 103-298, 108 Stat 1552, (codified as amended at 49 U.S.C. $\$ 40101$ (1994)).

${ }^{143}$ See id. $\S \S 2$ (a), 3. Our hypothetical future claimant, see supra pp. 436-37, would not be affected, since she was not aboard the plane that caused her harm. See id. § 2(b)(3). The definition of "general aviation aircraft" is limited to aircraft that carry fewer than twenty people and were not engaged in passenger carrying operations at the time of the accident. See id. $\$ 2$ (c). Component manufacturers are also covered. See id. $\S 2$ (a). Repose is not available where (1) the manufacturer knowingly misrepresents or conceals safety information from the Federal Aviation Administration; (2) the claimant was a passenger for purposes of receiving medical or emergency treatment; (3) the claimant was not aboard the aircraft at the time of the accident; or (4) the claimant's cause of action is based on the manufacturer's written warranties. See id. § 2(b)(1)-(4).
} 
lowing Professor Epstein's claim was making its way on appeal to the Eleventh Circuit. ${ }^{144}$

\section{A Flexible Approach}

Given the differing consequences of including future claims in the different types of cases, a flexible approach has superficial appeal. If bankruptcy's goal is to rehabilitate troubled companies, why not simply allow for inclusion or exclusion of future claims depending on the particular needs of the case? After all, if future claimants are not included, then their formal legal rights are not affected. Their rights outside of bankruptcy are preserved, so they are not harmed by their exclusion from the proceeding.

\section{The Flexible Approach in External Reorganization}

The flexible approach may do no harm in internal reorganization, but with respect to external reorganization, the above depiction ignores the liability avoidance that a flexible approach permits.

Flexibility to exclude future claims may be acceptable in internal reorganization, because the reorganized debtor survives to answer for claims-future or otherwise-that were not included. ${ }^{145}$ While such omitted claims, if valid, will collect 100-cent dollars from the reorganized debtor, the impact on other creditors and their collective settlement may be negligible, or at least acceptable. ${ }^{146}$ In that situation, omitting future claims may make sense.

The result in external reorganization, however, is quite different. As with the asset sale outside of bankruptcy, future claimants excluded from external reorganization may have no recourse against the going concern that survives. The debtor sells the business to a third party, sale proceeds are distributed and only the empty corporate shell remains. As in the nonbankruptcy context,

\footnotetext{
${ }^{144}$ See Telephone Interview with David Epstein, Professor, The University of Alabama School of Law (Apr. 8, 1998).

${ }^{145}$ Claimants' right to due process under the Fifth Amendment precludes their discharge based on a bankruptcy proceeding of which they received no notice and were otherwise excluded. See Dalton Dev. Project \#1 v. Unsecured Creditors Comm. (In re Unioil), 948 F.2d 678 (10th Cir. 1991); Reliable Electric Co. v. Olson Construction Co., 726 F.2d 620 (10th Cir. 1984).

${ }^{146}$ The transaction cost savings from not including future claims may more than make up for the costs to the reorganized debtor-and the indirect cost to current creditors in terms of the reduced value available for distribution-of having to pay future claims in full as they mature postbankruptcy. The aggregate amount of future claims liability, especially when discounted to present value, may not be worth the fuss of attempting to account for it in reorganization. In many, if not most cases, survival of the business will not depend on treating future claims. Aside from the transaction cost savings then, excluding future claims is essentially a distributional issue to which the nominally disadvantaged parties-current creditors-may consent.
} 
future claimants' rights against the bankruptcy acquirer will depend on state law successor liability rules.

Given that the firm's creditors-both current creditors and future claimants-are the firm's residual owners, it is largely current creditors' interests that are at stake in the issue of whether future claims are included in bankruptcy. Furthermore, inclusion of future claims is decided by the debtor's management, current creditors and the prospective acquirer, without input or participation by unrepresented future claimants. ${ }^{147}$ Much like the shareholders of the target firm outside of bankruptcy, ${ }^{148}$ current creditors, as the debtor's residual claimants, will attempt to structure a deal with the acquirer that maximizes their returns. This may not always coincide with the maximizing of sale proceeds or returns to creditors overall, or even with the preservation of the going concern. Current creditors will push for inclusion of future claims only when it is to their benefit. ${ }^{149}$ While the nominal justification for flexibility is the transaction cost savings from excluding future claims, excluding them also enables liability avoidance. Simply put, current creditors may improve their own recoveries by cutting future claims out of the bankruptcy distribution.

Initially, I consider current creditors' calculus-and the likelihood of future claimants' inclusion-absent transaction costs. ${ }^{150}$ This approach isolates current creditors' liability avoidance incentives. I later reintroduce transaction costs and draw some general conclusions as to their effect on current creditors' strategies and future claimants' prospects. ${ }^{151}$

\section{Current Creditors' Calculus}

Once the decision has been made to sell the assets, the debtor and current creditors have three basic options for disposition: (i) a "clean" going concern sale, which includes future claims in the bankruptcy

\footnotetext{
${ }^{147}$ Absent appointment of a legal representative, future claimants are not represented. But see In re Amatex Corp., 755 F.2d 1034, 1040-41 (3d Cir. 1985) (professed future claimant appeared seeking to intervene in opposition to appointment of legal representative). But appointment of a representative does not occur spontaneously. It occurs at the behest of a party that is represented in the bankruptcy. This suggests that no representative will be appointed for future claimants unless some other party stands to benefit.

${ }_{148}$ See supra Part II(A).

${ }^{149}$ Current creditors will not be able to dictate the form of the asset disposition. That decision is nominally the debtor's, although the court will certainly hear creditors' views in the process of approving the sale. See infra notes 205-06 and accompanying text. Once the decision is made to sell the assets, the debtor's management has no strong stake in the outcome. Absent side payments from an acquirer-e.g., the promise of a post-sale consulting contract-management has basically thrown in the towel by that point.

${ }^{150}$ I also assume no secured debt and no general administrative expenses. These latter assumptions are purely for ease of exposition and do not affect the analysis.

${ }^{151}$ See infra Part III(D)(3).
} 
distribution; (ii) a "quick and dirty" going concern sale, which excludes future claims and leaves the acquirer susceptible to postbankruptcy successor liability claims; and (iii) a piecemeal liquidation, which typically excludes future claims. When will current creditors push for the first option, such that future claims will be included?

\section{a. Asset Disposition Alternatives}

The acquirer will naturally pay a higher price for an enterprise free of the threat of successor liability than otherwise. With the clean sale, it will pay "full price" for "clean" assets, on the condition that future claims be provided for in the bankruptcy. ${ }^{152}$ While current creditors will have to share sale proceeds with future claimants, the former stand to benefit insofar as their distributions improve because of the acquirer's willingness to pay full price. Recoveries for both current creditors and future claimants will equal their pro rata shares of the debtor's going concern value. ${ }^{153}$ Put differently, as a group, current creditors recover the debtor's going concern value less future claimants' aggregate pro rata share of that value. ${ }^{154}$

Instead of the above scenario, current creditors might prefer a different deal. They might opt for a "quick and dirty" going concern

${ }^{152}$ This would, under my prescription, entitle the acquirer to an injunction against postbankruptcy successor liability claims. While the current state of the law offers no guarantees in this regard, the chances of successfully eliminating successor liability claims are much better if future claims are accounted for in the bankruptcy proceeding. See infra Part IV(A).

${ }^{153}$ For the clean going concern sale, we can represent each creditor's retum as follows.

If we let:

1. $L V$ equal the piecemeal liquidation value of the assets-that is, the scrap value;

2. GW equal the goodwill of the business-that is, the incremental value of the going concern over and above the scrap value;

3. $C C$ equal the aggregate amount of allowed current claims; and

4. $F C$ equal the estimated aggregate amount of allowed future claims liability, discounted to present value;

then, in a pro rata distribution among current and future claims, the payout ratio for each current and future claim (which we will refer to as $R_{c}$ ) is roughly

$$
R_{c}=\frac{L V+G W}{C C+F C}
$$

Each current and future claimant receives a bankruptcy distribution equal the amount of its allowed claim multiplied by the above fraction. Note that $R_{c}$ is simply the going concern value of the business, divided by the aggregate dollar amount of current and future claims.

Assume, for example, the following values for a hypothetical debtor: $L V=5 ; G W=7$; $C C=14 ; F C=10$. In a clean sale of the debtor's business, proceeds of 12 would be shared among 24 in current and future claims. $R_{c}$ would therefore equal 0.5 . Each claim therefore receives fifty cents on the dollar.

${ }^{154}$ Current creditors as a group stand to receive aggregate distributions (which we refer to as $D_{c}$ ) equaling

$$
D_{c}=L V+G W-(F C)\left(R_{c}\right) \text {. }
$$

Continuing with our hypothetical, current creditors as a group would stand to receive $D_{c}$ of $5+7$ (10)(.5) or 7 . 
sale, without including future claims in the proceeding. ${ }^{155}$ The acquirer runs the risk of being tagged in the future with successor liability under state law, ${ }^{156}$ and will discount its purchase price accordingly. ${ }^{157}$ Depending on the size of the discount, current creditors might decide they are better off sharing a smaller pie among themselves than having to include future claimants in the distribution. ${ }^{158}$

When will this occur? ${ }^{159}$ The acquirer would be willing to payand the distribution to current creditors in a quick and dirty sale would therefore equal-the going concern value of the business less some discount for successor liability. The lower the acquirer's perceived successor liability risk, the lower the discount and the greater the bankruptcy distribution to current creditors. In effect, the successor liability discount represents the amount of going concern value current creditors must forsake-indirectly - to future claimants as a group. When this amount is less than the amount current creditors would give up to future claimants in a pro rata distribution under a clean sale-that is, future claimants' aggregate pro rata share of the debtor's going concern value-current creditors as a group do better with a quick and dirty sale. ${ }^{160}$ The less likely the threat of

\footnotetext{
${ }^{155}$ Some type of free-and-clear sale order will be requested in any event, with bankruptcy courts generally willing to oblige. See infra notes $207-08$ and accompanying text.

${ }^{156}$ Bankruptcy will not likely-nor should it-be effective to preclude future claimants' successor liability rights if the proceeding fails to include them. See infra note 212 and accompanying text.

${ }^{157}$ See supra Part $\Pi(C)$. In a world of no transaction costs and perfect information, the acquirer would be indifferent as between paying full price for clean assets and a discounted price in the quick and dirty sale. In the real world, however, the acquirer will compare (1) the discount that current creditors would be willing to accept in return for not having to share with future claimants, with (2) the likely costs of having to pay future successor liability claims over time, discounted to present value. The acquirer might decide that bearing the risk of successor liability is cheaper than the immediate costs of including future claims in bankruptcy. Given the patchwork of state laws on successor products liability, which provide only porous protection for future claimants and only uncertain liability for any acquirer, an acquirer might decide to run the risk of future litigation, rather than pay a premium for a bankruptcy court injunction whose enforceability is in doubt.

${ }^{158}$ The aggregate distribution to current creditors (which we will refer to as $D_{q d}$ ) from the quick and dirty sale can be represented as:

$D_{q d}=L V+G W-(F C)\left(P_{s i}\right)$

where:
}

1. $P_{s l}$ is the aggregate probability of imposition of successor liability. Given the uneven prospects for successor liability following the sale, this probability may in many cases be small.

2. $(F C)\left(P_{s l}\right)$ therefore represents both the acquirer's estimate of the ultimate cost to it of successor liability and also (roughly) the discount by which it will reduce its bid price for the business.

$D_{q d}$, then, represents the going concern value of the business less the acquirer's successor liability discount.

${ }^{159}$ That is, when will $D_{q d}>D_{c}$ ? 
with a quick and dirty sale. ${ }^{160}$ The less likely the threat of successor liability, the better the quick and dirty sale looks for current creditors. 16

A third scenario is also possible. Current creditors may decide that they can maximize their bankruptcy distributions by forcing the debtor's piecemeal liquidation while excluding future claims. ${ }^{162}$ In

${ }^{160}$ This will turn largely on $P_{s l}$. Comparing the two formulae above for $D_{q d}$ and $D_{c}$ shows that current creditors will opt for a quick and dirty sale when $P_{s l}<R_{c}$, that is, when the aggregate probability of successor liability is less than the payout ratio from a clean sale. For example, if all unsecured creditors would receive a $50 \%$ payout if future claims were included, current creditors would exclude future claims when the aggregate probability of successor liability is less than $50 \%$.

To further refine our intuitions, consider the case where applicable state law did not recognize successor liability-and therefore $P_{s l}$ equals zero. There, current creditors would prefer the quick and dirty sale. Regardless of the amount of future claims liability, the sale would be effective to wipe out that liability. The acquirer would be willing to pay full price for the business, with no successor liability discount. Current creditors would enjoy the entire going concern value without having to share with future claims. In this situation, neither current creditors nor any other represented party has any incentive to include future claims. This is of course the same outcome as outside of bankruptcy under a regime without successor liability.

More formally, current creditors would take $L V+G W$, which is greater than their alternative going concern distribution of $L V+G W-(F C)\left(R_{c}\right)$.

By contrast, if successor liability were universal-and $P_{s t}$ were therefore equal to 1 - then current creditors would prefer to include future claims. Assuming going concern value is insufficient to pay all claims in full, current creditors would do better sharing with future claims the full price sale consideration that results from a clean sale, rather than keeping the entirety of the heavily discounted sale consideration that would result from a quick and dirty sale. In this latter case, the acquirer would attempt to take a successor liability discount equal to the full amount of future claims liability, since that would be the amount of future liability the acquirer could expect to face. Future claims would ultimately be paid in full from the acquirer pursuant to their successor liability rights. Current creditors would therefore take only the difference between going concern value and future claims liability. In the zero-sum game of distributing the going concern value among current and future claims, current creditors would rather include future claims, forcing them to share the pain of asset insufficiency. Excluding future claims, by contrast, would effectively grant them priority status.

More precisely, in this quick and dirty sale with $P_{s l}=1$, current creditors as a group would take $L V+G W-F C$, which is less than their distribution from the clean sale, $L V+G W-(F C)\left(R_{c}\right)$, assuming the debtor is insolvent. That is, the debtor's going concern value is insufficient to pay all current and future claims in full, and therefore $R_{c}<1$.

${ }^{161}$ Assume for our hypothetical debtor, see supra notes153-54, that $P_{s l}=0.2$. The acquirer will take a successor liability discount equal to 5 , and current creditors enjoy $D_{q d}$ of 5+7-2 or 10 . Because $P_{s l}<R_{c}$, the successor liability discount (equal to 2 ) is less than future claimants' share of clean sale distributions (equal to 5). Therefore $D_{q d}>D_{c}$, and current creditors will prefer the quick and dirty sale.

${ }_{162}$ See, for example, In re Amatex Corp., 755 F.2d 1034, 1036 (3d Cir. 1985), where the Creditors' Committee opposed the debtor's reorganization plan, which included participation by future claimants and appointment of a future claims representative. Instead, the Committee pushed for piecemeal liquidation and exclusion of future claims, arguing that future claimants are not "creditors" under the Code and therefore have no rights in bankruptcy. See id. at 1043. Future claims are typically, though not always, excluded in a piecemeal liquidation because of the perceived transaction costs of including them. See supra note 111 and accompanying text. However, future claimants should be included and receive equal treatment in piecemeal liquidation, both to vindicate bankruptcy's equal treatment norm and to eliminate current creditors' strategic incentive to dismantle an otherwise viable going concern. See infra note 182.

Current creditors may also have to contend with managerial reluctance to dismember the business. "Dissolution ... offends managers' sense of professionalism, since managers view 
the piecemeal liquidation, current creditors' aggregate distribution would equal the scrap value of the debtor's assets. ${ }^{163}$ If this scrap value is greater, relative to the aggregate amount of current claims, than the goodwill of the business, relative to the aggregate amount of future claims liability, then current creditors do better taking just the scrap value, rather than having to share the entire going concern value with a relatively large class of future claims. ${ }^{164}$

Current creditors may also prefer piecemeal liquidation to a quick and dirty going concern sale, since the latter runs the successor liability risk. ${ }^{165}$ Specifically, current creditors will prefer piecemeal liquidation when the successor liability discount is greater than the goodwill of the business. In that case, liquidation proceeds simply exceed the proceeds from the quick and dirty going concern sale, ${ }^{166}$ making liquidation a more attractive option for current creditors. ${ }^{167}$

\section{b. Future Claimants' Predicament}

Now, where does this leave future claimants? If their inclusion in external reorganization is optional, they would share in a bankruptcy distribution - that is, when current creditors and the acquirer would agree to a clean going concern sale-only if two conditions are met. ${ }^{168}$ First, there must be some relatively signifi-

their job to be running an ongoing organization." Merritt B. Fox, Corporate Successors Under Strict Liability: A General Economic Theory and the Case of CERCLA, 26 WAKE FOREST L. REV. 183, 206 (1991); see also Mark J. Roe, Corporate Strategic Reaction to Mass Tort, 72 VA. L. REV. 1, 8-9 (1986) (describing tendency of management to want to preserve going concern, whether such a strategy benefits creditors or shareholders).

${ }^{163}$ Current creditors' distribution in liquidation, $D_{\text {liq. }}$ equals $L V$.

${ }^{164}$ That is, when $L V / C C>G W I F C$, then $D_{l i q}>D_{c}$.

This will not hold for our hypothetical debtor. See supra notes 153-54. $L V / C C=5 / 14$; $G W / F C=7 / 10$. The latter is greater than the former, and $D_{c}$ of 7 is greater than $D_{\text {liq }}$ of 5 . So current creditors would not prefer piecemeal liquidation to a clean going concern sale.

${ }^{165}$ While future claimants would be excluded from the bankruptcy distribution in either case, a quick and dirty going concern sale is still better for future claimants, since some might be able to recover under state law successor liability rules.

${ }^{166}$ That is, when $(F C)\left(P_{s l}\right)>G W$, then $D_{l i q}>D_{q d .}$. To see why, recall that $D_{q d}$ is equal to the scrap value of the business $(L V)$, plus the goodwill $(G W)$, less the successor liability discount $\left((F C)\left(P_{s l}\right)\right)$. See supra note 158. Therefore, if the successor liability discount exceeds goodwill, then $D_{q d}$ will be less than $L V$, which is just $D_{l i q}$, and current creditors will prefer liquidation.

This will not hold for our hypothetical debtor. See supra notes $153,161 .(F C)\left(P_{s l}\right)=2$, while $G W=7 . D_{q d}$ (equal to 10 ) is therefore greater than $D_{l i q}$ (equal to 5 ), and current creditors will prefer the quick and dirty sale.

167 This is the same piecemeal liquidation problem that future claimants have with the firm's residual claimants outside of bankruptcy under a regime with successor liability, see supra notes 51-53 and accompanying text, except that in bankruptcy future claimants are residual claimants along with current creditors. Note that under state law a going concern asset sale is typically "quick and dirty" in the sense that there is no readily available mechanism for including future claims. See supra notes 32-36 and accompanying text. As in the nonbankruptcy case, piecemeal liquidation not only hurts future claimants, who are left with no recovery, but may also generate social costs with the destruction of going concern value.

${ }_{168}$ Again, we assume no transaction costs for now. . 
cant chance that the acquirer would be subject to successor liability following a quick and dirty going concern sale. ${ }^{169}$ Second, the value of the goodwill in the business must be high enough relative to the aggregate amount of future claims liability to entice current claimants to share going concern sale proceeds with future claimants, rather than liquidate. ${ }^{170}$

In effect, future claimants would be included, and their nonbankruptcy rights compromised, only when those nonbankruptcy rights might be worth something. Only when their successor liability claims have some promise, and the business has sufficient goodwill to induce current creditors to share going concern value with future claimants, would future claimants be included in bankruptcy. Their inclusion forces them to take scaled-down bankruptcy distributions worth less in the aggregate than if they had been free to pursue successor liability claims following bankruptcy.

Conversely, future claimants will be excluded when that is cheaper for the other parties-that is, when the nonbankruptcy rights of future claimants are marginal or worthless. When the overall probability of successor liability outside of bankruptcy is relatively remote, current creditors and the acquirer will agree to a quick and dirty sale. When the value of the goodwill is low compared to the aggregate amount of future claims, current creditors will opt for piecemeal liquidation, and future claims will be excluded. Therefore, preserving future claimants' nonbankruptcy rights while excluding them from the common pool is an empty promise. As in the nonbankruptcy context, residual owners-here, current creditors-will structure the disposition of assets to leave losses with future claimants. ${ }^{171}$

A flexible approach, then, enables current creditors to maximize their own returns at the expense of future claimants. Even crediting the stated rationale for flexibility-that is, to allow exclusion of future claims if the going concern can be saved without having to incur the administrative costs of addressing future claims - there is no guarantee that flexibility will be exercised with

\footnotetext{
${ }^{169}$ When $P_{s l}>R_{c}$, then $D_{c}>D_{q d}$. See supra note 160 and accompanying text.

${ }^{170}$ When $G W I F C>L V / C C$, then $D_{c}>D_{\text {liq. }}$. But cf. supra note 164 and accompanying text (explaining when current creditors would rather take the scrap value for themselves).

${ }^{171}$ In addition to protecting future claimants from the liability-minimizing strategies of other parties, mandatory inclusion of future claims puts a premium on the debtor's preservation of its liability insurance to the extent it has any. Insurance may provide a relatively low-cost device to insure a source of compensation to future claimants. By contrast, under a flexible approach, because losses may still be left with the victims, debtors and acquirers have imperfect incentives to maintain insurance, even though the debtor's existing policy may be available. See Paris Mfg. Corp. v. Ace Hardware Corp. (In re Paris Indus. Corp.), 132 B.R. 504, 509 (Bankr. D. Maine 1991), discussed infra note 212.
} 
this end in mind. Current creditors will push for the asset disposition that maximizes their returns, whether that course saves or destroys the going concern, and whether it minimizes transaction costs or not.

\section{Some Observations Concerning Transaction Costs}

Incorporating transaction costs complicates the analysis of current creditors' calculus to some extent, but does not alter the basic conclusion that a flexible approach enables current creditors to leave disproportionate losses with future claimants.

First, piecemeal liquidation will be the least costly in terms of transaction costs of addressing future claims. Assuming future claimants' exclusion from the liquidation distribution, ${ }^{172}$ piecemeal liquidation will incur no future claims transaction costs ("FCTC"). Because going concern sales will incur FCTC as described below, thereby reducing distributions to current creditors, accounting for transaction costs suggests that piecemeal liquidation will be even more attractive to current creditors than previously described under the zero-transaction-costs assumption.

Comparing FCTC as between the clean sale and the quick and dirty sale, a few generalizations are possible. In a quick and dirty sale, the FCTC will consist primarily of future litigation costs the acquirer incurs as future claimants appear to sue for successor liability. The acquirer will presumably discount its purchase price to account for the present value of these resolution costs, along with the expected costs of the successor liability itself-what I have styled the "successor liability discount." If we assume that resolution costs will vary roughly in proportion to the expected cost of the successor liability itself, then a small successor liability discount ${ }^{173}$ also implies low FCTC, and a high successor liability discount implies relatively high FCTC.

By contrast, with the clean sale, absent new approaches to the handling of future claims, the administrative costs of addressing them will include a significant fixed component. Certain initial costs must be incurred regardless of the aggregate amount of future claims liability. For example, retaining a representative for future claimants and conducting a future claims estimation proceeding will likely generate nontrivial costs, even for cases involving low levels of future claims liability. Therefore, FCTC will not simply vary proportionally with future claims liability. Instead, there will be some significant

\footnotetext{
${ }^{172}$ See supra note 162 and accompanying text.

${ }^{173}$ That is, $(F C)\left(P_{s t}\right)$ is small.
} 
fixed costs associated with addressing future claims at all, with "economies of scale" to be realized only at some higher level of aggregate future claims liability. In addition, these fixed costs must be paid up front as administrative expenses of the case. ${ }^{174}$ By contrast, the acquirer's resolution costs of successor liability claims are paid over time.

These contrasts suggest some cautious observations concerning the set of possible cases. Consider an ordering of cases based upon expected successor liability costs under a hypothetical quick and dirty sale. For cases where the expected costs of successor liability are low, ${ }^{175}$ a quick and dirty sale will generate lower FCTC than a clean sale. As the aggregate cost of successor liability increases-and with it, by presumption, aggregate resolution costs-the clean sale will approach parity with the quick and dirty sale in terms of FCTC efficiency. And somewhere along the spectrum of possible cases, expected successor liability costs and associated resolution costs will be high enough that a collectivized approach to addressing future claims will be more efficient, making the clean sale more attractive from the FCTC perspective.

What can this tell us about our analysis of the flexible approach? When expected costs of successor liability are low, that means that preservation of the going concern can be accomplished without accounting for future claims. An acquirer will agree to a quick and dirty sale because any specter of successor liability that survives to haunt the acquirer is manageable. A quick and dirty sale will "succeed" in saving the business. And as proponents of the flexible approach note, ignoring future claims avoids the higher FCTC that would have resulted from attempting to account for them in a clean sale. However, the factors contributing to this "success" must be examined more closely.

The quick and dirty sale may be possible only because significant future claims liability is eliminated by the sale and will not survive to swamp the post-reorganization enterprise in the form of successor liability claims. The sale has avoided not only certain FCTC but underlying future claims liability as well. Moreover, the more future claims liability that is wiped out by the sale, the greater also are the transaction cost savings. But only the latter savings are legitimate;

\footnotetext{
${ }^{174}$ See 11 U.S.C. § 507(a)(1) (1994).

${ }^{175}$ Note that this can occur either because (1) $F C$ is low, or (2) even if $F C$ is high, $P_{s l}$ is low. Given the relative unpopularity of successor liability among the courts, see supra notes 46-54 and accompanying text, we may speculate that many, if not most, future claims in cases resulting in a quick and dirty sale will never have to be dealt with by the acquirer. A quick and dirty bankruptcy sale may wipe out significant future claims liability and associated transaction costs.
} 
the former are not. With flexibility, current creditors stand to maximize their own recoveries via the quick and dirty sale, both by appropriating future claimants' distributions and by garnering transaction cost savings.

Will future claims ever be included? Incorporating transaction costs into our previous analysis suggests that current creditors will prefer a clean sale if both the aggregate probability ${ }^{176}$ and expected costs of successor liability are high. Only if the aggregate probability of successor liability is high will a quick and dirty sale fail to eliminate significant future claims liability. Current creditors would therefore have no opportunity to augment their bankruptcy distributions through significant future claims liability avoidance. Only if the expected costs of successor liability are high will FCTC of the clean sale be competitive with those of the quick and dirty sale. ${ }^{177}$

While transaction costs pose a formidable obstacle to inclusion of future claims in many cases, a flexible approach provides too easy a way out. Its initial premise is troubling. If transaction cost considerations may justify exclusion of future claims, then why not exclude other creditors on that basis as well $?^{178}$ Flexibility enables opportunism in the name of transaction cost savings, because plan proponents' discretion to exclude future claims is unlimited. There is therefore no guarantee under a flexible approach that future claims will be included even in large cases that might be able to support the costs of their inclusion. ${ }^{179}$ And crafting workable limits on this discretion would likely be problematic. ${ }^{180}$

\footnotetext{
${ }^{176}$ See supra note 160 and accompanying text.

177 If one of these two conditions fails to obtain, then current creditors' preference will depend on which factor-liability avoidance or FCTC savings/costs-outweighs the other.

In addition, in order to discourage piecemeal liquidation, the goodwill of the business relative to the aggregate amount of future claims liability would have to be significantly greater than the scrap value of the business relative to the aggregate amount of current claims. That is, $G W / F C \gg L V / C C$. Cf. supra note 170 and accompanying text. The goodwill of the business would have to be large enough to support both scaled down payments to future claimants and the transaction costs of including them. Otherwise, current creditors will push to liquidate.

${ }_{178}$ No one ever suggested in Texaco's bankruptcy that Penzoil should be excluded because of the transaction costs associated with liquidating that claim. I am being flip, of course. Addressing that claim was the sole purpose of the bankruptcy. See generally Robert H. Mnookin \& Robert B. Wilson, Rational Bargaining and Market Efficiency: Understanding Pennzoil v. Texaco, 75 VA. L. REV. 295 (1989) (describing Texaco bankruptcy and multimillion dollar litigation costs of Pennzoil dispute that precipitated the filing).

${ }^{179}$ For example, as a purely legal matter, mass tort debtors like Johns-Manville and A.H. Robins may have been able to sell their businesses out from under their future tort liabilities. They could have sold quick and dirty, distributing sale proceeds to current creditors and shareholders, and then liquidated, instead of, reorganizing and addressing future claims. Given the state of successor liability rules and the transaction costs of the traditional model for including future claims, shareholder returns might have improved dramatically with a quick and dirty sale. Liability avoidance on such a massive scale, however, would have generated public outrage and probably specific legislative sanction. See LoPucki, The Death of Liability, supra note 37, at 5154 (discussing cultural and political constraints on large-scale liability avoidance, noting in short
} 
The solution must lie in developing more economical approaches to treating future claims, ${ }^{181}$ not in leaving to other parties the discretion to compromise the interests of future claimants in the name of transaction cost savings. Inclusion of future claims must not be optional on the part of the debtor, current creditors or the acquirer of the business, but must be made mandatory in external reorganization. ${ }^{182}$.

\section{A Note on Equal Treatment}

Related to the mandatory inclusion of future claims is the requirement of equal treatment with other general creditors. ${ }^{183}$ Equal treatment of creditors similarly situated is a central bankruptcy policy. ${ }^{184}$

that "all hell would break loose"). That smaller cases fly below the public radar hardly suggests that liability avoidance on a smaller scale should be acceptable.

${ }^{180} \mathrm{Cf}$. Keating, supra note 58 at 1099-1100 (noting difficulty of using relative magnitude of future claims liability to determine whether to include future claims).

${ }^{181}$ I suggest possible approaches infra Part V. The best solution may not be a corporate, bankruptcy or tort law fix. First-party insurance or administrative compensation schemes, for example, offer plausible alternatives. See generally Kenneth S. Abraham, Individual Action and Collective Responsibility: The Dilemma of Mass Tort Reform, 73 VA. L. REV. 845, 906 (1987) (advocating expanded first-party insurance to compensate mass tort victims); Jennifer $\mathrm{H}$. Arlen, Compensation Systems and Efficient Deterrence, 52 MD. L. REV. 1093, 1115-20 (1993) (comparing administrative compensation scheme with first-party insurance in mass tort context).

${ }^{182}$ As an equal treatment rationale would suggest, this mandate should also apply to piecemeal liquidation in Chapter 7. Cf. NBRC REPORT, supra note 80, at 321 (“[M]ass future claimants of a debtor liquidating in Chapter 7 ... should be entitled to equal priority with present claimants."). Admittedly, the relatively steep transaction costs of mandating inclusion of future claims upon piecemeal liquidation may present the greatest challenge to the conceptual clarity herein proposed. However, forcing current claimants to share with future claimants regardless of the form of asset disposition may be necessary to eliminate any strategic incentive on the part of current claimants to push for piecemeal liquidation when a going concern might survive. Policing of this mandate in Chapter 7 may be problematic, however, as there will ordinarily be no going concern acquirer or other party with any stake in assuring that future claimants are provided for in the Chapter 7 distribution.

${ }^{183}$ A rule of equal treatment, of course, does not necessarily answer the detailed questions concerning what exactly counts as equal. Cf. GEORGE ORWELL, ANIMAL FARM 112 (Harcourt, Brace \& Co. 1946) ("All animals are equal, but some animals are more equal than others."). For example, a twenty percent payout to current creditors upon conclusion of the case may not necessarily require an immediate payout of the same pro rata amounts on behalf of future claims. Given that future claims by definition will not mature until some time after the business is sold and the case concluded-that is, future claimants have yet to suffer the harm demanding compensation-their pro rata payout should be discounted to present value.

${ }^{184}$ See supra note 68 and accompanying text; see also In re Dow Corning Corp., 211 B.R. 545, 565 (Bankr. E.D. Mich. 1997) (stating that tort and commercial claimants enjoy equal standing against debtor's assets and are entitled to share on a pro-rata basis); In re Am Ltd. Partnership, 140 B.R. 5, 14 (Bankr. D.D.C. 1992) (holding that tort and commercial claimants "enjoy equal standing against the debtor's assets").

On the other hand, equal treatment has also been described as a "weak" bankruptcy norm. See Carlson, supra note 31 , at $120 \mathrm{n} .5$ (arguing that in absence of competing policy considerations, foreclosure of future products liability claims is justified by "weak bankruptcy norm in favor of equality"); see also ROBERT CHARLES CLARK, CORPORATE LAW § 2.2 .2 (1986) (noting significant exceptions to equal treatment rule in bankruptcy); Roe, Mass Tort, supra note 2, at 855 (concluding that principles of fairness do not unambiguously suggest that future tort claim- 
In external reorganization, all general unsecured creditors should share available sale proceeds pro rata. Future claimants and other tort creditors should therefore be treated on a par with other unsecured creditors. ${ }^{185}$

One might oppose this requirement on the ground that it overcompensates future claimants, giving them rights in bankruptcy that they do not enjoy outside of bankruptcy. Professor Davis argues that future claimants' prospects of recovery outside of bankruptcy are so dim, given the vagaries of successor liability law and the possibility of the debtor's piecemeal liquidation, that an equal treatment rule would "overvalue" future claims. Outside of bankruptcy, future claimants may be vulnerable to dissolution strategies to which present claimants would not. "If these future claims were to have a right to participate equally with present claims, this would amount to a $s u b$ stantive right to improve their state law position."

Assuming the state law outcome is the proper benchmark for comparison, ${ }^{187}$ and taking Professor Davis's argument on its own terms, it

ants must be included in mass tort reorganization in order to assure temporal equality of treatment).

I agree with Professor Smith that fairness principles require equal treatment among current and future tort claimants. See Smith, supra note 8, at 378-82 (deriving equal treatment norm from Rawlsian hypothetical bargain analysis). And regardless of what other contexts may demand, as the following footnote explains, external reorganization presents the strongest case for equal treatment among all unsecured creditors.

${ }^{185}$ This distributional prescription follows naturally from a rule of mandatory inclusion of future claims. When the business is sold for cash, there is no reorganization-related justification for disparate treatment among groups of unsecured creditors. $C f$. Teamsters Nat'1 Freight Indus. Neg. Comm. v. United States Truck Co. (In re U.S. Truck Co.), 800 F.2d 581, 586-87 (6th Cir. 1986) (requiring some functional distinction among creditors in order to justify separate classification in internal reorganization plan).

This faimess-based equal treatment approach may be said to go farther than other proposals advocating mandatory inclusion of future claims insofar as it advances a distributional prescription across all unsecured creditor groups. Others either make no distributional claim-relying on other rationales for mandatory inclusion-or limit their distributional prescriptions to equity among tort claims, without focusing specifically on the external reorganization context. See supra note 90 and accompanying text. However, I suspect that in the external reorganization context, my distributional prescription would be uncontroversial to advocates for mandatory inclusion.

${ }^{186}$ Davis, supra note 78 , at 366 . Professor Davis argues both that future claims need not be included in the bankruptcy process, and that if included, they need not be treated equally with current creditors, but only "fairly, in a way that is at least commensurate with their prospects under state law." Id. at 366-67.

${ }^{187}$ Traditionally, nonbankruptcy outcomes have been relied upon as the appropriate baseline against which to track bankruptcy outcomes. See Butner v. United States, 440 U.S. 48 (1979).

Property interests are created and defined by state law. Unless some federal interest requires a different result, there is no reason why such interests should be analyzed differently simply because an interested party is involved in a bankruptcy proceeding. Uniform treatment of property interests by both state and federal courts within a State serves to reduce uncertainty, to discourage forum shopping, and to prevent a 
proves too much. The rule of equal treatment always improves the position of some creditors as compared to their would-be positions under state law. In the race of diligence outside of bankruptcy, ${ }^{188}$ certain creditors are always advantaged over others. When the equal treatment regime is triggered by the bankruptcy filing, creditors who would otherwise win the race to seize the debtor's assets always lose out, and creditors who would lose under state law benefit. ${ }^{189}$ That future claimants are vulnerable outside of bankruptcy does not distinguish them from many current creditors.

For example, small trade creditors are typically disadvantaged compared to institutional lenders. Institutional lenders include reporting requirements and covenant defaults in their lending documents. Their monitoring of the debtor's financial and operational performance will be much more active than that of trade creditors. ${ }^{190}$ They will typically realize higher percentage recoveries under-state law collection rules than small trade creditors. No one suggests that this circumstance justifies systematic favoritism of institutional lenders' unsecured claims in bankruptcy, or the systematic disfavoring of small trade creditors.

Are future claims different in kind from current claims, such that unequal treatment may be justified? After all, future claimants typically have no enforcement rights against the debtor outside of bankruptcy. ${ }^{191}$ Because future claimants could not even get to the starting

party from receiving "a windfall merely by reason of the happenstance of bankruptcy.

Id. at 55 (citing Lewis v. Manufacturers National Bank, 364 U.S. 603, 609 (1961)); see also Baird \& Jackson, supra note 55, at 110 (asserting that "bankruptcy law is primarily concerned with recognizing nonbankruptcy entitlements").

However, that traditional baseline has recently been called into question. See Lynn M. Lo Pucki, The Unsecured Creditor's Bargain, 80 VA. L. REV. 1887, 1945-47 (1994) [hereinafter LoPucki, The Unsecured Creditor's Bargain]. Professor LoPucki asserts that as a practical matter, most unsecured creditors have no substantive state law rights against the debtor's assets. For their repayment, they rely instead on procedural rights to extract payment from the debtor's encumbered cash flow, a practice he calls "cash-flow surfing." Because unsecured creditors have no substantive rights of any significance, attempting to replicate such rights in bankruptcy is futile. See id.

${ }^{188}$ See supra note 57 and accompanying text.

${ }^{189}$ Moreover, a fundamental purpose of the preference rules and the automatic stay is to discourage this destructive race to dismember the debtor. "If preferences are tolerated, a firm may be dismembered before bankruptcy and have no chance to survive as a going concern, even though everyone would have been better off if it had. Preference law exists because it deters gun-jumping." DOUGLAS G. BAIRD \& THOMAS H. JACKSON, CASES, PROBLEMS, AND MATERIALS ON BANKRUPTCY 425 ( 2 d ed. 1990).

${ }^{190}$ See Saul Levmore, Monitors and Freeriders in Commercial and Corporate Settings, 92 YALE L.J. 49, 53, 72 (1982) (noting relatively superior monitoring abilities of institutional creditors and bondholder trustees, and relatively inferior monitoring abilities of employees and occasional suppliers).

${ }^{191}$ As Professor Davis notes: 
line to compete in the race of diligence, this disability might justify their less favorable treatment in bankruptcy. However, this bright line between current and future claimants blurs upon closer inspection. Future claimants do have rights under state law. In some states, a cause of action may accrue simply on the basis of exposure to a hazard, even before injuries have developed. ${ }^{192}$ Future claimants, as contingent creditors, may also fall within the protections of the fraudulent transfer laws. ${ }^{193}$ At least one state, Delaware, requires that provision be made for future claimants upon a corporation's dissolution. ${ }^{194}$ And finally, the nonbankruptcy analog brings us full circle, since successor liability may be available outside of bankruptcy to compensate future claimants despite their ostensible disability in the race of diligence. ${ }^{195}$

More generally, rather than focusing on ways that future claimants may be exploited under state law to decide their proper bankruptcy treatment, we need only recognize their status as creditors in order to conclude that they deserve equal treatment. While discounting their claims to present value seems appropriate, it seems inappropriate to discount them-and only them-based on creditor vulnerabilities under state law, vulnerabilities that bankruptcy is specifically designed to ameliorate.

[T] these instances, present claimants will be able to employ a number of devices, such as attachment, execution, fraudulent conveyance law, injunction or receivership, to protect their prospective recovery. Future claims, in contrast, would have no say in the matter. If a claim cannot yet be asserted, the claimant is powerless to affect the legitimate affairs of its future obligor.

Davis, supra note 78 , at 365 .

${ }_{192}$ For example, Judge Posner noted in In re UNR Indus., 725 F.2d 1111 (7th Cir. 1983), that medical evidence exists that shows microscopic injury to the body as soon as asbestos fibers lodge in the lungs, and that "states differ on whether a cause of action in an asbestosis case accrues upon inhalation or not until there is palpable disease or the disease is discovered." Id. at 1119 (citations omitted); see also Roe, Mass Tort, supra note 2, at $896 \mathrm{n} .153$ (suggesting that in some states, a cause of action accrues upon mere exposure to a hazard, even without manifestation of injury).

${ }^{193}$ See American Sur. Co. v. Marotta, 287 U.S. 513 (1933) (noting common law rule that creditor with only contingent claim is nonetheless protected against fraudulent conveyance); UNIF. FRAUDULENT TRANSFERS ACT $§ 1(3)$ (defining "claim" to include contingent and unmatured rights to payment).

${ }^{194}$ See supra note 34.

${ }^{195}$ Moreover, successor liability may sometimes favor future claimants over current creditors in the state law race. See infra notes 230-31 and accompanying text. However, that does not suggest that future claimants should do better in bankruptcy than other creditors. 


\section{E. Inadequacy of Reform Proposals}

Some advocates for the flexible approach overlook the potential for opportunism in external reorganization. ${ }^{196}$ The NBC proposal fails even to explain its flexible approach, ${ }^{197}$ let alone analyze possible problems of strategic behavior. The NBRC proposal, while noting the desirability of treating all claimants equally whether reorganization is accomplished internally or externally by way of sale, ${ }^{198}$ fails to account for the possibility of a quick and dirty sale. Under the NBRC proposal, an acquirer qualifies for formal insulation from successor liability only if sufficient protections are provided for future claimants in the bankruptcy proceeding. ${ }^{199}$ So far, so good. However, the proposal too optimistically finds this requirement sufficient to preclude the parties from "act[ing] strategically to disadvantage one class of claimants." 200 It fails to consider that when successor liability risk is low, the parties will not need a bankruptcy injunction to cut off the rights of future claimants. As in the nonbankruptcy context, the sale itself and subsequent distribution to current creditors will suffice.

\section{SUCCESSOR LIABILITY AND EXTERNAL REORGANIZATION}

Provided that future claimants share ratably in the bankruptcy sale proceeds, then as with other creditors, future claimants' rights in external reorganization should be exclusive. Their successor liability rights must be extinguished. Bankruptcy courts have resorted to the

\footnotetext{
${ }^{196}$ Professor Davis has noted the perilous consequences for future claimants excluded from external reorganization. See Davis, supra note 78, at 367 ("It is in a sale, as opposed to a reorganization, that future claims are in the greatest danger of losing their fair share."). He also notes the strategic incentives of current creditors to exclude future claims. See id. However, this predicament does not disturb him as much as it does me. He seems content to let future claimants take their chances under state law successor liability rules. See id. at 371-72. I critique his approach supra Part III(D)(4).

197 See supra note 96; see also Kathryn R. Heidt, Comment, Future Claims in Bankruptcy: The NBC Amendments Do Not Go Far Enough, 69 AM. BANKR. LJ. 515, 519 (1995) [hereinafter Heidt, The NBC Amendments] (criticizing flexible approach advocated in original edition of NBC Final Report, which "leaves too much control over the treatment of future claims in the hands of the plan proponent").

${ }_{199}^{198}$ See NBRC REPORT, supra note 80, at 348-50.
}

The Proposal would prevent a debtor or trustee from selling off the major assets of the business and cutting off mass future claimants' access unless the debtor satisfied the requirements for treating mass future claims. Without the appointment of a mass future claims representative, for example, the successor would not be protected from liability for mass future claims.

Id. at 349 .

${ }^{200} \mathrm{Id}$. 
channeling injunction ${ }^{201}$ to permanently enjoin successor liability claims, while channeling future claims to a trust or other payment mechanism established to satisfy such claims as they mature.

Bankruptcy theorists support this resolution. ${ }^{202}$ However, its legal basis is unclear. The channeling injunction is not obviously authorized by the Code in the external reorganization context, and prominent courts have questioned the permissibility of bankruptcy court injunctions against successor liability actions. This Part argues that authority for enjoining successor liability claims in external reorganization is well within the general equitable powers of the bankruptcy court. ${ }^{203}$

\section{A. Current Confusion}

A going concern sale in bankruptcy will typically occur in Chapter $11 .^{204}$ It is typically effected either pursuant to the debtor's general authority to deal with estate property in bankruptcy, ${ }^{205}$ or through

201 This term was coined in the mass tort bankruptcies. Channeling injunctions have been used both in internal reorganization in connection with the Chapter 11 discharge, and in external reorganization, where no discharge applies. See supra note 106 and accompanying text.

202 See JACKSON, LOGIC AND LIMITS, supra note 56, at 53 ("The preferable solution ... is to include the nonmanifested tort victims in the bankruptcy process as holders of claims, so they get to share in the assets, but then to sell the assets free of all such claims."); Baird, The Uneasy Case, supra note 5, at 145-46 ("A sale of assets to a third party must be free of all claims against it. Those who have claims against the firm must satisfy themselves out of the proceeds of the sale. If they are able to pursue the assets at a later time, the price that can be realized from the sale will be depressed."); Carlson, supra note 31, at 145 (arguing for bankruptcy foreclosure of "products liability servitude"); Heidt, Changing Paradigm, supra note 11, at 1084 (asserting that successor liability law is inconsistent with bankruptcy policy); Jackson, Translating Assets and Liabilities, supra note 80, at 96-97 (stating that successorship doctrine is unnecessary when unproved tort claims share in bankruptcy distribution).

${ }^{203}$ Section 105(a) describes the bankruptcy court's general equitable powers. "The court may issue any order, process, or judgment that is necessary or appropriate to carry out the provisions of this title." 11 U.S.C. $§ 105$ (a) (1994). The purpose is "to assure the bankruptcy courts" power to take whatever action is appropriate or necessary in aid of the exercise of their jurisdiction." 2 COLLIER ON BANKRUPTCY II 105.01 (15th ed. 1997). This power is not limitless. Its exercise must be consistent with the provisions of the Code. It "does not authorize the bankruptcy courts to create substantive rights that are otherwise unavailable under applicable law, or constitute a roving commission to do equity." United States v. Sutton, 786 F.2d 1305, 1308 (5th Cir. 1986) (citation omitted).

${ }^{204}$ The sale could theoretically occur in Chapter 7. However, as Professor Baird has noted, going concern sales in Chapter 7 are rare. "As a practical matter, ... we never see 'goingconcern' liquidations in Chapter 7. The managers of a corporation prefer the control and the presumption of continued operation that exists in Chapter 11. They will not file a Chapter 7 petition as long as they harbor any hope for the firm." BAIRD, supra note 89 , at 16 .

205 "The trustee, after notice and a hearing, may use, sell, or lease, other than in the ordinary course of business, property of the estate." 11 U.S.C. $\$ 363(b)(1)$ (1994). While section 363 refers to the trustee's authority, under section 1107(a), the debtor in possession is authorized to run the business in Chapter 11, with the rights and powers of a trustee. See id. $\S 1107$ (a). 
a liquidating plan. ${ }^{206}$ Section $363(\mathrm{f})$ is often relied upon for authority to sell the assets "free and clear" of all liens and claims, ${ }^{207}$ including successor liability claims. ${ }^{208}$ However, whether a successor liability claim qualifies as an "interest in property" referred to in the statute is doubtful. $^{209}$ The Chapter 11 discharge is also unavailable in this

\footnotetext{
${ }^{206}$ A liquidating plan calls for the sale of all or substantially all assets of the estate and payment of creditor claims from the sale proceeds. Such a plan is authorized under section 1123 (b)(4). See id. $\$ 1123$ (b)(4); see also infra note 211 and accompanying text.

${ }^{207}$ Section $363(f)$ provides that the trustee may sell estate property free and clear of any interest in such property of any entity other than the estate only if:

(1) applicable nonbankruptcy law permits sale of such property free and clear of such interest;

(2) such entity consents;

(3) such interest is a lien and the price at which such property is to be sold is greater than the aggregate value of all liens on such property;

(4) such interest is in bona fide dispute; or

(5) such entity could be compelled, in a legal or equitable proceeding, to accept a money satisfaction of such interest.

11 U.S.C. \$ 363(f) (1994).

${ }^{208}$ Sales free and clear of successor liability claims have been authorized by bankruptcy courts under section 363 (f) even though future claims were ignored. See, e.g., Western Auto Supply Co. v. Savage Arms, Inc. (In re Savage Indus., Inc.), 43 F.3d 714 (1st Cir. 1994) (overruling bankruptcy court holding that section $363(f)$ authorizes injunction against successor liability claims where tort victims never received notice of bankruptcy); American Living Sys. v. Bonapfel (In re All American of Ashburn, Inc.), 56 B.R. 186, 189 (Bankr. N.D. Ga.), aff'd sub nom. Griffin v. Bonapfel, 805 F.2d 1515 (11th Cir. 1986) (finding that sale of assets "free and clear of all claims pursuant to 11 U.S.C. $\S 363(f)$ " precludes successor products liability claim against asset purchaser) (emphasis supplied); see also In re Leckie Smokeless Coal Co., 99 F.3d 573 (4th Cir. 1996) (holding that "successor in interest" liability for benefit plan premium under Coal Act constitutes "interest in property," such that section 363(f) authorizes bankruptcy sale free and clear of such liability); WBQ Partnership v. Commonwealth of Virginia Dep't of Med. Assistance Servs. (In re WBQ Partnership), 189 B.R. 97 (Bankr. E.D. Va. 1995) (finding that section 363(f) authorizes bankruptcy sale of substantially all debtor's assets, free and clear of state agency's state law right to proceed against asset purchaser for depreciation recapture relating to Medicaid cost reimbursements previously received by debtor); Lee R. Bogdanoff, The Purchase and Sale of Assets in Reorganization Cases-Of Interest and Principal, of Principles and Interests, 47 BUS. LAW. 1367, 1419 (1992) (proposing that "greater" power to sell assets free and clear of liens under section 363(f) should include "lesser" power to sell assets free and clear of successor liability "interests").

${ }^{209}$ See, e.g., Zerand-Bernal Group, Inc. v. Cox, 23 F.3d 159, 163 (7th Cir. 1994) (Posner, C.J.) (finding that sale pursuant to section 363(f) may cleanse assets of liens and other encumbrances, but not successor product liability claims); Fairchild Aircraft Inc. v. Cambell (In re Fairchild Aircraft Corp.), 184 B.R. 910 (Bankr. W.D. Tex. 1995) (holding that section 363(f) sale may only extinguish in rem interests which have attached to property, but not in personam liabilities such as "trailing" tort liability), vacated, 220 B.R. 909 (Bankr. W.D. Tex. 1998); Wilkerson v. C.O. Porter Machinery Co., 567 A.2d 598 (N.J. Super. 1989) (finding that section 363(f) does not address successor liability claims); see also Western Auto Supply Co. v. Savage Arms, Inc. (In re Savage Indus., Inc.), 43 F.3d 714 (1st Cir. 1994) (explicitly reserving question of whether section $363(\mathrm{f})$ enables extinguishment of state law successor "product-line" liability claims, while holding that because of inadequate notice to such claimants, their claims survived against both the debtor and asset purchaser); Volvo White Truck Corp. v. Chambersburg Beverage, Inc. (In re White Motor Credit Corp.), 75 B.R. 944, 948 (Bankr. N.D. Ohio 1987) (holding that section 363(f) only authorizes sales free and clear of specific interests in property being sold, but is inapplicable to sales free and clear of tort claims or other general unsecured claims, as such claimants have no specific interest in property; but that authority for
} 
context to foreclose the rights of future claimants. Chapter 11 discharge is reserved for debtors reorganizing internally. ${ }^{210}$ The liquidating debtor, by contrast, is left with no business to run and therefore does not need a discharge. ${ }^{211}$

sale free and clear of successor liability may be found in section 105(a), and is coextensive with power to discharge claims under plan of reorganization).

The NBC and NBRC each recommend amendment of section 363 in order to make clear that asset sales under that provision would be free and clear of successor liability claims, provided that future claims were included in the bankruptcy proceeding and accorded proper treatment. See NBC FINAL REPORT, supra note 80 , at $41-42$; NBRC REPORT, supra note 80 , at 34750. One problem with this approach is that at the time of any asset sale under section 363 , the specific bankruptcy treatment of future claims will probably not have been decided yet-and almost certainly not documented in any binding fashion. Therefore, any free and clear sale order would necessarily be conditional, and would ultimately need to be supplemented by a permanent channeling injunction at the end of the case. Or if no free and clear sale order could issue until treatment of future claims had been determined, that would ordinarily be at a point late in the case, such that a permanent injunction could issue with, or shortly after issuance of, the free and clear sale order. See NBRC REPORT, supra note 80, at 350 ("E]ntering a free and clear order would entail a finding that the debtor satisfied the requisite standards for treating mass future claims."). These proposals, then, would not in practice differ much from the channeling injunction approach described herein.

${ }^{20}$ With internal reorganization, the Chapter 11 discharge is probably effective to preclude successor liability claims, assuming future claims are dealt with in the case. As the court stated in Volvo White Truck Corp. v. Chambersburg Beverage, Inc. (In re White Motor Credit Corp.), 75 B.R. 944 (Bankr. N.D. Ohio 1987):

The liability which state law imposes through successor liability is that of the manufacturer. The federal purpose of final resolution and discharge of corporate debt is clearly compromised by imposing successor liability on purchasers of assets when the underlying liability has been discharged under a plan of reorganization. Moreover, successor liability is precluded by Section 1141(c) which specifically frees debtors' property from creditors' claims. Successor liability in these circumstances has, therefore, been pre-empted by the Bankruptcy Code.

Id. at 950-51. The reorganization plan at issue had made provision for future claims. See id. at 947; Conway v. White Trucks, 885 F.2d 90, 91 (3d Cir. 1989) (describing provision for future claims). Ironically, however, the claim at issue was not a future claim but a claim involving a preconfirmation accident. The tort victim filed a proof of claim but also attempted to sue Volvo as a successor. See Volvo White Truck, 75 B.R. at 947.

${ }^{211} 11$ U.S.C. $\$ 1141$ (c), (d)(3) (1994). Section 1141(d)(3) provides that:

The confurmation of a plan does not discharge a debtor if-

(A) the plan provides for the liquidation of all or substantially all of the property of the estate;

(B) the debtor does not engage in business after consummation of the plan; and

(C) the debtor would be denied a discharge under section 727(a) of this title if the case were a case under chapter 7 of this title.

11 U.S.C. § 1141(d)(3) (1994).

A plan would probably be considered a liquidating plan if it called for sale of all or substantially all of the debtor's assets-whether sold as a going concern or piecemeal. Section 1141 (d)(3) is a "corollary provision" to section 727(a), see 8 COLLIER ON BANKRUPTCY I 1141.05[3], at 1141-49 (15th rev. ed. 1997), which precludes any entity liquidating in Chapter 7 from receiving a Chapter 7 discharge. See 11 U.S.C. $\$ 727($ a)(1) (1994). This Chapter 7 prohibition does not depend on whether the Chapter 7 trustee sells the assets piecemeal or as a going concern. Therefore, it would seem reasonable to expect that the corollary prohibition of section 1141(d)(3) would result in a similar outcome-that is, denial of a discharge to a Chapter 11 debtor that is left with no assets or business to run. See also Michigan Employment Sec. Comm'n v. Wolverine Radio Co., Inc. (In re Wolverine Radio Co.), 930 F.2d 1132, 1147 n.21 
This lack of explicit statutory authority for the channeling injunction, coupled with the fact that future claims are ordinarily ignored in external reorganization, has led some courts to issue broad pronouncements declaring bankruptcy's inability to affect successor liability claims.

When future claimants are excluded from bankruptcy's collective settlement, courts have almost uniformly-and quite correctly-held that the preceding bankruptcy could not affect their rights. ${ }^{212}$ Barring successor liability claims in that context would violate fundamental notions of due process, eliminating future claimants' rights through legal proceedings of which they received no notice and in which they were unrepresented. ${ }^{213}$ By contrast, postbankruptcy successor liability-if available under the applicable state law-enables tort victims to be compensated. As in the nonbankruptcy context, it prevents the firm from using a sale and liquidation to leave losses from productrelated injuries with the future victims. The necessity for successor liability would not appear to be affected by the fact of a bankruptcy that failed to consider future claimants' rights. ${ }^{214}$

(6th Cir. 1991) ("A corporation in Chapter 11 that does not continue in business after plan confirmation does not receive a discharge.").

${ }^{212}$ See, e.g., Western Auto Supply Co. v. Savage Arms, Inc. (In re Savage Indus., Inc.), 43 F.3d 714 (1st Cir. 1994); Zerand-Bernal Group, Inc. v. Cox, 23 F.3d 159 (7th Cir. 1994); Fairchild Aircraft Inc. v. Cambell (In re Fairchild Aircraft Corp.), 184 B.R. 910 (Bankr. W.D. Tex. 1995), vacated, 220 B.R. 909 (Bankr. W.D. Tex. 1998); cf. Paris Mfg. Corp. v. Ace Hardware Corp. (In re Paris Indus. Corp.), 132 B.R. 504 (D. Maine 1991). In Paris, the district court upheld the bankruptcy court's injunction against interim claimants' prosecution of their state court products liability suit despite the fact that no bankruptcy notice was given. The court reasoned that the claimants were not prejudiced by the lack of notice, since they were not challenging the adequacy of the sale proceeds, which were insufficient to pay any unsecured claims. Instead, the claimants complained that the trustee had canceled the debtor's products liability insurance that would have covered their claims. Had they received notice of the sale, the claimants would have appeared before the court in order to persuade the trustee to maintain the insurance. See id. at 509.

Another issue that has arisen is whether the bankruptcy court has jurisdiction to enjoin a successor liability suit after the bankruptcy case has been closed. Compare Zerand-Bernal Group, Inc. v. Cox, 23 F.3d 159 (7th Cir. 1994) (finding lack of jurisdiction), with Volvo White Truck Corp. v. Chambersburg Beverage, Inc. (In re White Motor Credit Corp.), 75 B.R. 944 (Bankr. N.D. Ohio 1987) (finding jurisdiction). That issue will not be addressed herein.

${ }^{213}$ See In re Savage Indus., Inc., 43 F.3d at 720 n.9.

The Code "notice" requirements have even greater force in a case like the present, where the order approving the proposed sale authorized a transfer of substantially all chapter 11 estate assets-for present purposes, the functional equivalent of an order confirming a conventional chapter 11 reorganization plan. As such, the order confirming a chapter 11 liquidation sale warrants especial bankruptcy court scrutiny.

Id.

${ }^{214}$ Assuming the debtor is insolvent, successor liability in this context will prefer future claimants over current creditors. However, this successor liability threat may be necessary to provide the proper inducement to current creditors and the acquirer to include future claims. See infra Part V(C). 
Unfortunately, that future claims are typically ignored in external reorganization has led some courts to conclude that future claims may never be affected in external reorganization. Under this view, external reorganization is ineffective to foreclose successor liability claims, even if provision were made for payment of future claims along with other claims against the debtor.

The case of Zerand-Bernal Group, Inc. v. Cox ${ }^{215}$ provides an example. $^{216}$ The Seventh Circuit affirmed a bankruptcy court's conclusion that it lacked jurisdiction to issue an injunction barring successor liability claims brought four and a half years after the bankruptcy sale at issue. ${ }^{217}$ While future claims had been ignored in the bankruptcy, the appellate court opined that even if future claimants had been provided for, their successor liability claims could not have been enjoined. ${ }^{218}$ The court found no statutory authority for such an injunction. ${ }^{219}$ The court was also unimpressed with the notion that the threat of successor liability would depress sale prices for assets in bankruptcy. To allow the court to enjoin successor liability claims on that basis would justify:

a blanket power to enjoin all future lawsuits against a buyer at a bankruptcy sale in order to maximize the sale price: more, that the court could in effect immunize such buyers from all state and federal laws that might reduce the value of the assets bought from the bankrupt. ${ }^{220}$

This sort of unlimited power would provide "incentive to enter bankruptcy for reasons that have nothing to do with the purposes of bankruptcy law."221 The court concluded that bankruptcy can never affect successor liability claims. ${ }^{222}$

\footnotetext{
21523 F.3d 159 (7th Cir. 1994) (Posner, J.).

${ }^{216}$ See also Chicago Truck Drivers, Helpers and Warehouse Workers Union Pension Fund v. Tasemkin, Inc., 59 F.3d 48 (7th Cir. 1995); R.C.M. Executive Gallery Corp. v. Rols Capital Co., 901 F. Supp. 630 (S.D.N.Y. 1995); Wilkerson v. C.O. Porter Machinery Co., 567 A.2d 598 (N.J. Super. 1989).

217 The original sale agreement approved by the bankruptcy court was by its terms made subject to the court's reservation of jurisdiction to enjoin subsequent successor liability claims. Zerand-Bernal, 23 F.3d at 161.

${ }^{218}$ Judge Posner has in other circumstances, however, been more receptive to bankruptcy treatment of future claims. See supra note 125 .

${ }^{219}$ The court cites to 11 U.S.C. $\$ 524(\mathrm{e})(1994)$ for the proposition that discharge applies only to protect the debtor. However, as already mentioned, the liquidating debtor does not receive a discharge in any event. The channeling injunction does not depend on the debtor's discharge. See infra Part IV(B).

${ }^{220}$ Zerand-Bernal, 23 F.3d at 163.

${ }^{221} \mathrm{Id}$.

222 According to the court, no bankruptcy mechanism is necessary to foreclose future claimants' successor liability claims, since inclusion of future claims in the bankruptcy would have rendered successor liability unavailable as a matter of state law. "[T] he successorship doctrine
} 
Because future claims were excluded in Zerand, survival of successor liability was the correct result. ${ }^{223}$ However, contrary to the court's assertion, in the proper circumstances an injunction against successor liability is central to the purposes of bankruptcy law. The channeling injunction is the functional equivalent in external reorganization to the Chapter 11 discharge in internal reorganization. ${ }^{224}$ Although the liquidating debtor is not entitled to a discharge and does not need one, the going concern that survives external reorganization does require insulation from the debtor's preconfirmation obligations. An understanding of the role of Chapter 11 discharge will make the point.

\section{B. Chapter 11 Discharge and the Channeling Injunction}

\section{Functional Parallels}

Unlike an individual debtor in consumer bankruptcy, a corporation reorganizing in Chapter 11 does not get a fresh start. ${ }^{225}$ It does not emerge from bankruptcy with a clean slate. Its slate will only be as clean as creditors are willing to allow. Moreover, creditors negotiate not only with the debtor concerning treatment of their respective claims in reorganization. As important, they also negotiate with each other, apportioning what all understand is a fixed pool of value. The process is multilateral, with settlement among creditors as a critical feature. What any creditor receives depends to a great extent on what other creditors are willing to give up.

Because of this creditor interdependence, Chapter 11 discharge functions not only to shield the emerging debtor from its creditors' prebankruptcy claims, but also to protect creditors from each other. The discharge insulates the postconfirmation going concern from pre-

\footnotetext{
... is inapplicable if the plaintiff had a chance to obtain a legal remedy against the predecessor, even so limited a remedy as that afforded by the filing of a claim in bankruptcy." Id. This assertion concerning state law outcomes may not be universally true. See Wilkerson v. C.O. Porter Machinery Co., 567 A.2d 598 (N.J. Super. 1989) (finding that application of postbankruptcy successor liability was unaffected by whether future claimant had received distribution in bankruptcy).

${ }^{223}$ The court was correct in noting that the possibility of depressed asset sale bids could not justify "allow[ing] the parties to bankruptcy sales to extinguish the rights of third parties, here future tort claimants, without notice to them or (as notice might well be infeasible) any consideration of their interests." Zerand-Bernal, 23 F.3d at 163.

224 See supra note 73-74 and accompanying text (concerning the parallels between internal and external reorganization).

${ }^{225}$ See JACKSON, LOGIC AND LIMITS, supra note 56, at 191 ("Corporations that reorganize under chapter 11 do, to be sure, receive a discharge. ... [H] the reasons for such discharge are derived from a financial fresh-start policy.") (citations omitted).
} 
confirmation claims, thereby preserving for creditors the value of their respective postconfirmation stakes in the reorganized debtor that were negotiated as part of the plan. The discharge operates to enforce the finality of the collective settlement. ${ }^{226}$ It limits each creditor to its agreed share of the common pool.

The channeling injunction performs this same function in external reorganization. Whether the going concern is ultimately owned by prebankruptcy creditors or third parties or some combination, all involved must be assured of the finality of any collective settlement. Where creditors as a group opt to cash out by selling the going concern to a third party, the future claims channeling injunction serves that purpose. ${ }^{227}$ It assures each creditor, including each future claimant, that no other creditor may appropriate more than its share of the common pool. ${ }^{228}$

\section{The Channeling Injunction and Bankruptcy Norms}

Absent a channeling injunction, some future claimants may stand to recover in full from the acquirer. However, such recoveries come at the expense of the common pool, as a result of the acquirer's successor liability discount. ${ }^{229}$ This dampening of bids for the business frustrates bankruptcy's attempt to maximize recoveries for creditors

\footnotetext{
${ }^{226}$ See BAIRD, supra note 89, at 69 ("The discharge ... is necessary to rearrange the firm's capital structure. One cannot recapitalize a firm unless all existing rights against it are canceled and new ones are issued in their stead.").

${ }^{227}$ Cf. Baird \& Jackson, supra note 55, at 110 n.45. Professors Baird and Jackson describe the role of the corporate discharge in Chapter 11 as a device to effect parity among the various asset deployment choices that are available to the debtor's investors. Internal reorganization is in effect a going concern "sale" in which creditors sell the firm to themselves, foregoing their prebankruptcy claims against the debtor's assets in exchange for their agreed plan consideration. The discharge enables this "sale" of assets free of prebankruptcy claims, in the same way that sale to a third party and dissolution would effect this outcome outside of bankruptcy. Without the discharge in Chapter 11 reorganization, the debtor's investors could not make an unbiased decision concerning asset deployment, since only disposition to a third party would be effective to free the assets from their presale liabilities. Id.

Successor liability, ironically, raises the converse problem. Unlike most corporate liabilities, successor liability claims may survive the sale and dissolution outside of bankruptcy. But they probably do not survive the Chapter 11 discharge if the debtor reorganizes internally and includes future claims in the proceeding. See supra note 210. Absent the channeling injunction, successor liability claims would also survive the going concern sale in Chapter 11 , that is, the "external reorganization." Therefore, the channeling injunction is necessary to equalize treatment of future claims as between internal and external reorganization.

${ }^{228}$ Moreover, under this approach, section 1141 (c) may provide statutory authority for the channeling injunction. It states that "after confirmation of a plan, the property dealt with by the plan is free and clear of all claims and interests of creditors." 11 U.S.C. $\S 1141$ (c) (1994). The statute contains an exception relating to the corporate debtor's ineligibility for discharge in the case of a liquidating plan. However, as the analysis in the text suggests, the appropriateness of the channeling injunction should not depend on the debtor's eligibility for discharge, and section 1141 (c) may plausibly be interpreted consistently with this idea.

${ }^{229}$ See supra notes $49-53,160-61$ and accompanying text.
} 
as a group. Sale of the going concern may depend on bankruptcy's ability to include future claims and foreclose attendant successor liability rights. Disability in this regard may inhibit any sale and imperil the survival of the business--the very same problem created by successor liability outside of bankruptcy. ${ }^{230}$

Survival of successor liability claims also creates equal treatment problems. The successor liability discount may draw 100-cent dollars from the common pool to pay future claims liability not satisfied in bankruptcy. The future claimant stands to have her claim paid in full by the successor following bankruptcy, while "like" current creditors receive only partial satisfaction from a diminished pool of sale proceeds. $^{231}$ The future claimant is thereby accorded priority treatment, an outcome inconsistent with the equal treatment norm. ${ }^{232}$

The channeling injunction assures that the proceeds from selling the business will not be diminished by the threat of postbankruptcy successor liability suits, and that no future claimant will be able to obtain more than her due at the expense of other creditors.

Moreover, any external reorganization could be structured as an internal reorganization in order to assure a Chapter 11 discharge. The third-party acquirer, instead of purchasing the debtor's business outright, could contribute the purchase price to the internally reorganized entity in exchange for its new common stock. The discharge would hold future claimants to the terms of the collective settlement. It would foreclose the rights of future claimants against the reorganized entity, as long as future claims were provided for in the plan. ${ }^{233}$ Insulation of the going concern from the claims of prepetition creditors,

\footnotetext{
${ }^{230}$ See supra notes 51-53 and accompanying text. Professor Carlson discusses this problem of effective foreclosure rules, noting that the rules must provide for the termination of enough pre-existing interests in the property subject to sale, such that a prospective purchaser is given something worth buying. See Carlson, supra note 31, at 121.

231 "The successor liability specter would chill and deleteriously affect sales of corporate assets, forcing debtors to accept less on sales to compensate for this potential liability. This negative effect on sales would only benefit product liability claimants, thereby subverting specific statutory priorities established by the Bankruptcy Code." Volvo White Truck Corp. v. Chambersburg Beverage, Inc. (In re White Motor Credit Corp.), 75 B.R. 944, 951 (Bankr. N.D. Ohio 1987).

${ }^{232}$ See Heidt, The NBC Amendments, supra note 197, at 520. Moreover, the future tort victim is preferred over the current tort victim, though the same debtor conduct is responsible for both injuries. "Only serendipity explains why one claimant is bound by the plan, while the other is permitted to pursue full recovery, based only upon the timing of the injury, and serendipity seems a poor decisional point for such a major policy choice." Fairchild Aircraft Inc. v. Cambell (In re Fairchild Aircraft Corp.), 184 B.R. 910, 918 (Bankr. W.D. Tex. 1995), vacated, 220 B.R. 909 (Bankr. W.D. Tex. 1998). A similar problem of differential treatment occurs if future claims are not all included in bankruptcy. See supra notes 85, 87-89 and accompanying text.

${ }^{233}$ See supra note 210 .
} 
however, should not depend on the form of the reorganization or the structuring of the sale transaction. ${ }^{234}$

Provided that the collective settlement in bankruptcy includes future claimants, then that settlement should foreclose their rights against the going concern. The channeling injunction does that. Contrary to the court's assertions in Zerand, ${ }^{235}$ such an injunction would not purport to enjoin "all future lawsuits" against an acquirer, but only those of future claimants whose rights had been recognized in bankruptcy. It would not purport to bind all creditors of the acquirer, but only future claimants, who are primarily creditors of the debtor.

\section{Future Claimants' Position}

We might sympathize with the future tort victim whose injury manifests itself only long after the corporate tortfeasor has disappeared. $^{236}$ Even when she is included in the bankruptcy distribution,

\footnotetext{
234 The proposal of the National Bankruptcy Review Commission makes the same point. See NBRC REPORT, supra note 80, at 350.

In fact, there may be good reason not to force a contrived internal reorganization on a thirdparty acquirer for the sole purpose of foreclosing future claims. Internal reorganization is ordinarily expensive. It typically requires either (1) formal valuation of both the going concern and any "tickets" issued to prebankruptcy creditors in consideration for their claims, see generally Clark, supra note 73 , at $1252-54$, or (2) multilateral negotiation in order to avoid the cost and uncertainty of such formal valuations. See Roe, Successor Liability, supra note 36, at 1570 n.28 ("[T]he task of valuation is so onerous, unpredictable, and ill-suited to judicial treatment that one might argue that the current framework for corporation reorganization in chapter 11 of the Bankruptcy Code was constructed largely to avoid the difficulties of judicial valuation.").

By contrast, the sale of the going concern to a third party generally avoids these valuation questions, as well as the costs of strategic behavior inherent in plan negotiation. The typical sale consideration will be cash or marketable securities, whose value is readily ascertainable. Once the business is sold, the question of its value is answered. The distribution will follow absolute priority, with little room to haggle over valuation. See Baird, The Uneasy Case, supra note 5, at 139 (noting that while outright sale in bankruptcy eliminates valuation and distribution issues, internal reorganization requires a complex proceeding fraught with opportunities for strategic behavior by parties in interest).

Forcing the parties to cast their transaction as an internal reorganization might leave room for disgruntled parties to reopen issues-valuation, for example-that would be foreclosed in a straight sale via a liquidating plan. That would unnecessarily increase the costs of the transaction for all interested parties. It might force the acquirer, an outsider, to have to navigate through the internecine conflicts among prebankruptcy creditors and equityholders. In the worst case, it might saddle the acquirer with the burden of having to negotiate a capital structure with "lenders" not of her own choosing, when ex hypothesi she would have been willing to pay cash for the business.

235 See supra note 220 and accompanying text.

${ }^{236}$ While voluntary creditors have some ability to diversify across more than one borrower and to "adjust" for credit risk, tort victims do not choose their "borrowers"-i.e., their tortfeasors. Tort creditors are therefore in a precarious position, and future tort creditors even more so. See generally RichaRd A. BREAley \& Stewart C. MYERS, PRINCIPLes OF CORPORATE FINANCE 136-39 (4th ed. 1991) (describing how diversification reduces unsystematic risk); Reinier H. Kraakman, Corporate Liability Strategies and the Costs of Legal Controls, 93 YALE
} 
her share of the common pool may not be enough to compensate fully for her injuries. But the impulse to compensate future tort claimants through successor liability has no conceptual justification following bankruptcy.

Recognizing the special vulnerability of tort creditors does not justify divergent treatment as between current and future claimants, or between current and future tort victims. In the context of external reorganization, successor liability favors future over current claimants, including known tort victims. It enables full recovery only for future tort victims. It does not operate to favor tort and other involuntary claimants over contract creditors. It effectively shifts losses from future claimants-providing them full compensation-to the tortfeasor's residual claimants. But in bankruptcy, the residual claimants will be other creditors, including the future claimants' fellow tort victims whose injuries have already appeared, as well as other involuntary creditors. Commentators have argued for special treatment of tort creditors generally. ${ }^{237}$ However, short of any fundamental change, tort creditors are merely unsecured creditors under the current system. The future tort victim deserves no less, but also no more, than the current tort victim or other unsecured creditor.

As with the debtor's other creditors, future claimants' ratable share of the common pool should be their exclusive recovery. The court's power to enjoin successor liability claims as part of an external reorganization should therefore be co-extensive with the scope of the discharge of claims in internal reorganization. ${ }^{238}$ That future tort victims

L.J. 857, 870 (1984) ("[T]ort victims ... cannot protect themselves by refusing the firm 'credit' or by demanding a security interest in firm property before accidents.").

${ }_{237}$ Recognizing that tort creditors are different from contract creditors, theorists have proposed special treatment for tort claimants - either modification of corporate limited liability rules with respect to tort claimants, see Henry Hansmann \& Reinier Kraakman, Toward Unlimited Shareholder Liability for Corporate Torts, 100 YALE L.J. 1879, 1907 (1991) (advocating pro rata shareholder liability for tort obligations), the granting to tort claimants of priority over secured and/or other contract creditors, see LoPucki, The Unsecured Creditor's Bargain, supra note 187, or both. See David W. Leebron, Limited Liability, Tort Victims, and Creditors, 91 COLUM. L. REV. 1565 (1991).

${ }^{238}$ See Volvo White Truck Corp. v. Chambersburg Beverage, Inc. (In re White Motor Credit Corp.), 75 B.R. 944, 948 (Bankr. N.D. Ohio 1987) (holding that section 105(a) provides authority to sell assets free and clear of successor liability claims, and that such authority is coextensive with Chapter 11 discharge power).

This analysis is not affected by the existence of section 524(e), which states that the discharge "does not affect the liability of any other entity on, or the property of any other entity for, [the discharged] debt." 11 U.S.C. \$ 524(e) (1994). As the text explains, the channeling injunction does not depend on the particular debtor's eligibility for discharge. However, some courts have seized on this provision to suggest that successor liability can not be affected by bankruptcy. See Zerand-Bernal Group, Inc. v. Cox, 23 F.3d 159, 163 (7th Cir. 1994) ("DD]ischarge operates as an injunction, but only against the ... debtor."); Wilkerson v. C.O. Porter Machinery Co., 567 A.2d 598, 603-04 (N.J. Super. 1989). 
may not be paid in full in bankruptcy does not imply that successor liability is appropriate. No unsecured creditor will be paid in full. Receiving her due from the bankruptcy proceeding should preclude the future claimant from a second recovery. Further rights against the acquirer must be terminated for the collective good.

\section{IMPLEMENTATION}

Having concluded that future claims must always be included in external reorganization and receive equal treatment with current creditors, and that successor liability claims must be extinguished, we turn in this Part to issues of implementation.

\section{A. Prospects for the Traditional Model}

Appropriate methods for implementing comprehensive inclusion of future claims will vary depending on the size of the case and the perceived magnitude of future claims liability. In terms of aligning practice with theory, the truly difficult cases will involve small and medium-sized companies, for which administrative expenses will always be of special concern. Outside of the large cases, the "traditional model"239 may be cost prohibitive. Each element of the approach - the future claims representative, claims estimation, a claims resolution facility and associated trust-becomes relatively more expensive as the size of the estate gets smaller, but the due process and other concerns remain the same. ${ }^{240}$

Collectivizing some aspects of the traditional model, however, may be possible consistent with the rights of future claimants. Institutions already exist that might be adapted for this purpose. For in-

\footnotetext{
Section 524(e) has been read to preclude release of third parties, such as the debtor's coobligors or guarantors, who have independent obligations to pay debts as to which the debtor enjoys a discharge. See, e.g., American Hardwoods, Inc. v. Deutsche Credit Corp. (In re American Hardwoods), 885 F.2d 621, 626 (9th Cir. 1993) (holding that confirmed plan could not insulate debtor's nondebtor guarantors from liability through permanent injunction). However, where a nondebtor third party, who might otherwise be liable as the debtor's co-obligor, contributes to the funding of the reorganization, courts have been willing to rely on their general equitable powers to insulate that contributing third party from postbankruptcy suit. See MenardSanford v. Mabey (In re A.H. Robins, Inc.), 880 F.2d 694 (4th Cir. 1989); In re Master Mortgage Inv. Fund, Inc., 168 B.R. 930, 935 (Bankr. W.D. Mo. 1994) (enumerating factors justifying injunction insulating nondebtor third party, including (1) nondebtor's contribution of substantial assets to reorganization and (2) fact that suit against the contributing nondebtor would deplete estate assets because of an identity of interest between the debtor and the nondebtor third party). With external reorganization, of course, the acquirer funds the entire reorganization through its payment of the purchase price for the business. The threat of postbankruptcy successor liability diminishes that pool of estate assets. See generally Ralph Brubaker, Bankruptcy Injunctions and Complex Litigation: A Critical Reappraisal of Non-Debtor Releases in Chapter 11 Reorganizations, 1997 U. ILL. L. REV. 959.

${ }^{239}$ See supra Part III(C)(1).

${ }^{240}$ See supra Part III(C)(2).
} 
stance, while appointment of a future claims representative may not be cost-justified in each case, ${ }^{241}$ perhaps a panel system could be devised, similar to the current system of panel trustees for Chapter 7 cases. The small cases may not be lucrative for a "panel future claims representative," but a balance of small and larger cases could provide sufficient compensation to entice lawyers to want to serve. ${ }^{242}$

Estimation as well need not be an extravagant proceeding, but might be tailored to what the estate can bear. As resort to claims estimation increases, one would hope that more accurate, less expensive methods will develop. ${ }^{243}$ No estimation will be perfect in any event. As long as the procedure chosen provides reasonable accuracy and does not systematically bias the outcome in either direction, it may be a legitimate exercise of bankruptcy powers. ${ }^{244}$

The same may be said for the claims resolution mechanism. The costs of full-blown nonbankruptcy litigation "may make little sense

${ }^{241}$ Whether due process requires appointment of a future claims representative in bankruptcy is an unsettled question. Compare Ralph R. Mabey \& Jamie Andra Gavrin, Constitutional Limitations on the Discharge of Future Claims in Bankruptcy, 44 S.C. L. REV. 745, 781 (1993) ("Mullane usually mandates ... the appointment of a future claims representative in order to provide future claims access to a court hearing."), with Frank R. Kennedy \& Gerald K. Smith, Postconfirmation Issues: The Effects of Confirmation and Postconfirmation Proceedings, 44 S.C. L. REV. 621, 692 (1993) ("It is ... arguable whether either [the Fifth or Fourteenth Amendments] embraces the notion that a representative must always be appointed to represent the claims of unknown claimants."). However, implementing the traditional approach without representation for future claimants seems problematic. It would seem, for example, that future claimants would have to be represented in any estimation proceeding purporting to limit their recoveries by capping the debtor's aggregate liability. See supra note 103 and accompanying text.

${ }^{242}$ Chapter 7 trustee fees are tied to the level of disbursements made in a given case. See 11 U.S.C. $\$ 326$ (a) (1994) (describing fee schedule for Chapter 7 trustee). Because most Chapter 7 cases are "no-asset" cases, the trustee is paid only a nominal fee for her services in those cases. Most cases are therefore not lucrative for a panel trustee, but the compensation from the "asset" cases ultimately makes up for having to administer the "no-asset" cases. See Warren, supra note 55, at 364-65 (describing cross-subsidization of trustees' fees).

${ }^{243}$ See generally David S. Salsburg \& Jack F. Williams, A Statistical Approach to Claims Estimation in Bankruptcy, 32 WAKE FOREST L. REV. 1119, 1139 (1997) (describing progressive construction of statistical models for claims estimation based on past outcomes).

${ }^{244}$ As Professor Jackson notes:

It may be in the interests of all the claimants to expedite the [claims liquidation] process and thereby scale down its costs. For that reason a bankruptcy system might legitimately adopt its own procedures for estimating the expected value of a claim if successful and the probability of its success. Although the normal nonbankruptcy trial procedures may be watered down or eliminated, as long as there is no bias in the direction of estimation, then there is no particular reason to think that the value of those nonbankruptcy procedural rights has been interfered with.

JACKSON, LOGIC AND LIMITS, supra note 56, at 45.

In addition, formal estimation may not always be necessary. In some circumstances, acquirers might be willing to purchase businesses subject to overhanging future liabilities if they could get comfortable with the potential range of costs. Formal fixing or capping of the liability may therefore not be necessary, either to preserve going concern value or to assure compensation to future claimants. Based on this idea, I have proposed a low-cost approach to treatment of future claims in external reorganization infra at Part V(B). 
when the resulting claim will receive only ten cents on the dollar .... The relatively fixed costs ... associated with nonbankruptcy claim liquidation procedures may loom unduly large when translated into the bankruptcy forum."245 The streamlined claims resolution mechanisms adopted in the large cases, while perhaps not exemplary in all respects, may at least provide some lessons for smaller cases. Alternative dispute resolution mechanisms, for example, would seem to make eminent sense in terms of transaction cost savings. ${ }^{246}$ As with future claims representation, the claims resolution function could be collectivized and cross-subsidized, with staffing either by private parties or public officials.

The cost of the claims resolution process, of course, will turn in part on the nature of the tort and the complexity of the eligibility criteria set as part of the reorganization plan. As with any administrative or adjudicative process, attempting relatively finer distinctions will generally result in relatively greater resolution costs. Transaction cost considerations should therefore inform not only the structuring of the claims resolution process but also the determination of substantive eligibility criteria. ${ }^{247}$

With respect to the payment trust, collectivized administration seems to hold the most promise. Each case involving future claims does not require its own separate asset management and distribution system. Once the level of future claimants' pro rata recovery is set, ${ }^{248}$ a claims resolution procedure put in place, and estate assets set aside, asset management and payment of claims are simply investment and administrative functions, respectively, requiring no exercise of legal discretion on the part of administrators. ${ }^{249}$ Public and private institutions already exist that perform similar functions. Insurance and trust companies sell similar services in the private sector. As the legal

\footnotetext{
245 JACKSON, LOGIC AND LIMITS, supra note 56, at 45.

${ }^{246}$ See supra note 104 and accompanying text.

${ }^{247}$ In the A.H. Robins bankruptcy, for example, the claims resolution facility offered claimants a menu of procedural options with more expensive claims requiring more information and more process. See supra note 104. "The more compensation sought by a claimant, the more information the fund required." McGovern, supra note 107, at 682. In this manner, the fund let claimants "self-select the optimal combination of price and transaction costs." Id.

${ }^{248}$ After estimation of aggregate future claims liability, discounted to present value, the payout ratio for current and future claimants is set simply by dividing asset sale proceeds-net of administrative expenses and other priority claims-by the total amount of current and future claims.

${ }^{249}$ This is not to suggest that management of the trust assets would simply be mechanical. Different investment strategies may affect recoveries for some future claimants, depending on when their respective claims mature. However, assumptions concerning reasonable investment returns were presumably incorporated into the future claims estimation process, in order to determine the proper amount of estate assets to allocate to future claimants. A prudent investment strategy and corresponding investment guidelines would seem to be uncontroversial in this context.
} 
system adapts to address future claims issues more coherently and comprehensively, demand for low-cost solutions will no doubt increase. Trust and insurance products designed specifically for future claims administration and compensation may not be too far off. ${ }^{250}$

Bankruptcy trustees perform similar functions as well. Trustees in Chapter 13 consumer cases and Chapter 7 liquidation cases hold and manage estate assets and disburse innumerable small payments to commercial and other creditors. And these systems are self-supporting. ${ }^{251}$ The increasing likelihood of the existence and recognition of future claims in smaller business bankruptcies suggests that a government institution for collective asset management and distribution on behalf of future claimants may be appropriate.

\section{B. One Alternative: Commensurate Discounted Assumption}

The traditional model may not be the only option for addressing future claims. One plausible alternative, which I call Commensurate Discounted Assumption ("CDA"), may avoid the costs of formal estimation of future claims liability and the expense of establishing and maintaining a trust to distribute future payments. A future claims representative may also be unnecessary in some instances.

\section{The Idea}

Under CDA, the acquirer simply assumes the obligation to pay future claims as they mature and are liquidated-but at a discount. Each future claimant would be entitled to pro rata payment of its claim from the acquirer, at a percentage commensurate with current creditors' actual recoveries from distribution of sale proceeds under the liquidating plan. The required percentage payout to future claimants would be determined implicitly, based on the results of negotiation among the acquirer, the debtor and current creditors over the purchase price for the business. Whatever percentage recovery is received by current creditors based on a pro rata distribution of all sale proceeds among them, that percentage recovery will also determine the extent of the acquirer's liability and future claimants' entitlement.

For example, if current claims of $\$ 70$ million share $\$ 7$ million in the bankruptcy distribution, that $10 \%$ payout also sets the acquirer's commensurate liability - and the "CDA payout ratio"-for future

\footnotetext{
${ }^{250}$ See Keating, supra note 58, at 1101-02 (suggesting that assets set aside for future claimants be used to purchase insurance on their behalf, instead of simply placing such funds in trust).

${ }^{251}$ See Warren, supra note 55, at 364-65 (describing profit making by U.S. Trustee system and fee system for private trustees).
} 
claims. As future claims mature and are liquidated, the acquirer must compensate each at $10 \%$ of the amount of its liquidated claim.

An acquirer would certainly discount its bid price to account for this assumed CDA liability, but this should not prejudice current creditors, since any discount would only reflect the cost of payments to future claimants commensurate with those received by current claimants. The common pool represented by the asset sale proceeds would contract, but only by the amount of pro rata payments to which future claimants are entitled.

Assume, for example, that the acquirer estimates the operational value of the business at $\$ 10$ million. It estimates aggregate future claims liability at $\$ 30$ million in present value terms, and there are current claims totaling $\$ 70$ million. Under these assumptions, and assuming no secured debt, and administrative and other priority claims to be zero (purely for ease of computation), the acquirer will not bid the "full price" of $\$ 10$ million for the business. Instead it will bid $\$ 7$ million, taking a $\$ 3$ million discount for future claims liability. Because it estimates that future claims constitute $30 \%$ of the debtor's unsecured claims, it will reserve $30 \%$ of its "full price" bid to compensate future claims as they arise. ${ }^{252}$

As a result of the acquirer's $\$ 7$ million bid, current claims of $\$ 70$ million will be paid $10 \%$ of their claims, which also sets the acquirer's commensurate liability for the estimated $\$ 30$ million in future claims. Over time, the acquirer will end up paying a present value of $\$ 3$ million in order to retire future claims as they mature, each at $10 \%$ of its claim. In this way, the "full price" of $\$ 10$ million is shared ratably among current and future claims.

In effect, this process allows protection of future claimants' interests through the bargaining of current creditors, the debtor and the acquirer over the purchase price of the business. Current creditors will push for a high valuation of the going concern, with a minimal discount for any future claims liability, thereby maximizing returns to themselves. The acquirer's approach will be just the opposite. It will wish to pay as little as possible for the going concern, and to that end will claim a heavy burden of future claims liability. Because the ultimate percentage payout received by current creditors will affect the acquirer's assumed obligation to pay future claimants, the acquirer has additional incentive to bid low.

The advantages to this approach are several. First, the parties in interest can avoid the costs of a formal estimation proceeding. Parties

\footnotetext{
${ }^{252}$ The acquirer will also attempt to discount for its anticipated transaction costs of liquidating future claims as they mature.
} 
will certainly have to invest resources privately estimating future claims liability, which will inform their negotiation over the sale price. However, no formal estimation process need be conducted, and no current representation for future claimants need necessarily be procured. As long as current creditors have a large enough stake in the outcome to police or participate in the bargaining over the purchase price, ${ }^{253}$ future claimants are protected by current creditors' desire to maximize their own returns. This approach also eliminates the need for a special mechanism to effect future distributions. Future claims would simply be paid by the going concern-that is, the acquirer-as they arise and are liquidated. ${ }^{254}$

Future claims are not prejudiced, as their recoveries have not been limited by any formal estimation. Only the acquirer's commensurate liability - and the corresponding CDA payout ratio-is set as a result of the bankruptcy sale. Each future claimant's actual recovery from the acquirer would be determined upon the claim's liquidation by multiplying the liquidated face amount by the CDA payout ratio. ${ }^{255}$

This bargaining structure in effect uses a crude market mechanism to substitute for future claims estimation. It allows parties with their own money at stake to negotiate a deal that also determines treatment of future claimants. Because it is their money at stake, we can have some confidence that current creditors and the acquirer will be vigorous in their negotiation. And whatever deal is struck, future claimants will receive equal treatment with current creditors, discounted to present value.

Put another way, the acquirer pays the "full" purchase price for the business in multiple installments. The first installment is paid to the Chapter 11 estate in order to acquire formal title to the business. This first installment goes to pay current creditors, who are the debtor's residual claimants whose identities have been determined as of the date of plan confirmation. Further installments are paid to future claimants-that is, the residual claimants whose identities are determined postbankruptcy-as their claims mature.

\section{Limitations and Implications}

Certain caveats apply to this CDA approach.

${ }^{253}$ Appointment of a creditors' committee would also serve this function. See 11 U.S.C. $\S 1102(a)(1)(1994)$.

${ }^{254}$ A streamlined claims resolution process could also be set up in bankruptcy as part of the liquidating plan.

${ }^{255}$ Building on the example in the text, the future claimant whose injury has matured and whose claim is liquidated at a face amount of $\$ 100,000$ will be paid $10 \%$ of that, or $\$ 10,000$, by the acquirer. 


\section{a. Due Process}

One obvious caveat relates to due process. Absent appointment of a future claims representative, it is unclear whether the interests of future claimants could be said to have been adequately represented in the bargaining process. No party to the bankruptcy would have exactly the same set of interests as future claimants. ${ }^{256}$

On the other hand, as long as the particular circumstances in a given case impart confidence that the debtor, current creditors and the acquirer bargained at arm's length over the purchase price for the business, then the interests of future claimants would seem to have been protected. Future claimants' interests coincide with those of current creditors in holding out for the highest possible purchase price, since that dollar figure provides the numerator for the fraction that forms the CDA payout ratio. Future claimants would also want to minimize the denominator of that fraction, which is simply the dollar amount of allowed current claims. Presumably the debtor and current creditors may be relied upon to raise allowance issues with respect to current claims, since current creditors stand to improve their recoveries to the extent they can eliminate other current creditors claiming a share in the sale proceeds. As long as no side payments are allowed from the acquirer to current creditors, and as long as current creditors have enough stake in the outcome to participate, it would appear that the bargaining interests of current creditors also serve to protect the interests of future claimants. ${ }^{257}$

${ }^{256}$ Cf. Hansberry v. Lee, 311 U.S. 32, 43 (1940) (opining that absent parties may be bound where they are adequately represented by present parties). "[W]here the interests of those not joined are of the same class as the interests of those who are, and where it is considered that the latter fairly represent the former in the prosecution of the litigation ... the court will proceed to a decree." Id. at $41-42$.

${ }^{257}$ See id. at 42 ("[T] $]$ here has been a failure of due process only in those cases where it cannot be said that the procedure adopted, fairly insures the protection of the interests of absent parties who are to be bound by it.").

Notice should also be given. Some future claimants may be identifiable, and as to them actual notice is appropriate. See Tulsa Prof'1 Collection Servs. v. Pope, 485 U.S. 478, 491 (1988) (holding that creditor known or reasonably ascertainable is entitled to notice by mail or other means of actual notice); Waterman S.S. Corp. v. Aguiar (In re Waterman S.S. Corp.), 157 B.R. 220, 222 (S.D.N.Y. 1993) (describing notice requirements with respect to known versus unidentifiable future claimants). Publication notice should also be made for unidentifiable claimants. While no future claimant may have any incentive to participate, see supra note 10 and accompanying text, to the extent practicable, future claimants should be given an opportunity to appear, if for no other purpose than to monitor the transaction that will affect their potential future recoveries.

Ultimately, if there is doubt concerning due process questions, a future claims representative could be appointed. For example, if future claims liability far outweighed current claims liability, current creditors might have no strong incentive to police the bargaining over the pur- 
Due process protection for future claimants is certainly an important issue. However, it would be ironic if due process constraints were construed to defeat the interests of the supposed beneficiaries of those constraints. ${ }^{258}$ If due process concerns preclude bankruptcy participation by future claimants in the small cases because the traditional approach is cost prohibitive and no other approach will do, many excluded future claimants may end up with no recovery at all. State law remedies may be nonexistent. That consideration should inform any due process inquiry.

\section{b. Successor Liability Issues}

The CDA approach is at heart a species of successor liability, but with a bankruptcy twist. As such, it is susceptible to criticisms of the same flavor as those aimed at common law successor liability. ${ }^{259}$ Asking an acquirer to assume open-ended liability may kill any deal. ${ }^{200}$ The parties' respective assessments of the present value of aggregate future claims liability may differ by a wide margin. To the extent that the aggregate amount of liability is difficult to predict within an acceptable range of uncertainty, the parties may not be able to settle on a mutually acceptable price for the business.

On the other hand, with the liability discounted, the acceptable range of uncertainty becomes proportionally greater, since each dollar of unexpected liability is paid only a proportionate amount based on the CDA payout ratio. The effect of scaling down the liability is that the deal can tolerate a higher degree of uncertainty than outside of bankruptcy.

Moreover, the CDA approach is not mandatory. It merely provides one alternative for the parties to structure a deal that also accounts for future claims. Under my prescription, compensating future claimants is mandatory. But whether that obligation is paid by the

chase price for the business. In that situation, appointment of a future claims representative might be necessary.

${ }^{258}$ See generally Roe, Mass Tort, supra note 2, at 898-904 (noting possible detriment to future claimants' interests from too formalistic a construction of due process requirements).

${ }^{259}$ See supra notes $46-50$ and accompanying text.

260 "Open-ended" may be a bit of an overstatement. An acquirer may limit its CDA liability simply by placing the acquired business in a separate corporation and incurring secured debt. Liability would thereby be limited to the consideration paid for the business, net of the secured debt. See LoPucki, The Death of Liability, supra note 37, at 14-23 (describing liability avoidance strategies of secured debt and multiple incorporation). Of course, there may be financing issues that make secured debt undesirable. There may be operational reasons to integrate the acquired business into the acquirer's existing operations, in which case separate incorporation might not be effective to quarantine the liability of the acquired business. See In re Palmer Trading, Inc., 695 F.2d 1012, 1017 (7th Cir. 1982) (discussing commingling of business affairs among affiliates as factor in favor of piercing corporate veil). 
estate directly-as occurs under the traditional approach-or the acquirer assumes it, is up to the parties to decide. Presumably, whichever route is cheaper in transaction cost terms would be preferred. Any approach attempting formally to cap future claims liability would require an estimation proceeding at which a future claims representative would participate. But that route may be cost prohibitive. The CDA approach may be the cheaper option. In any event, current creditors may have no choice, in the face of acquirer trepidation concerning CDA liability, to consent to whatever discounted sale price necessary to sell the going concern. ${ }^{261}$

\section{c. Transaction Costs in Claims Resolution}

Another effect of scaling down future claims liability is that transaction costs become a relatively greater deterrent to future claimants' pursuit of their claims. If the CDA payout ratio is low, future claimants may not find it worthwhile to pursue pennies on the dollar for their tort harms.

In this situation, the design of a low-cost claims resolution mechanism may be critical to ensuring that compensation is ultimately delivered. Otherwise, the acquirer's CDA liability is merely theoretical. The acquirer, the debtor and current creditors could negotiate the sale of the business under the comfortable assumption that few future claimants would ever come forward. The going concern sale in bankruptcy would therefore, as a practical matter, leave future claimants with no remedy.

\section{Policing Inclusion of Future Claims}

Even if a costless scheme could be devised for inclusion of future claims, there remains the general problem of mandating its use. Even if the CDA approach "works," no one before the court may have any interest in raising it or proposing any compensation for future claims. $^{262}$

In some cases, the acquirer may insist that future claims be addressed. ${ }^{263}$ It may seek a CDA order, as that would reduce its liability

\footnotetext{
${ }^{261}$ Under my proposal, piecemeal liquidation is no more attractive an alternative, since current creditors will have to share with future claims even in that event. See supra note 182.

${ }^{262}$ Appointment of a future claims representative does not occur spontaneously. See supra note 147 and accompanying text. Of course, future liabilities might arise that could not have been anticipated at the time of bankruptcy. That these liabilities were ignored in bankruptcy is understandable. They present a much more difficult question than anticipated products liability. A considered discussion of this question must be deferred for another day.

${ }^{263}$ In Piper, for example, it was the acquirer's insistence that led to appointment of a future claims representative. See supra note 130.
} 
as compared to full-blown successor liability outside of bankruptcy. ${ }^{264}$ However, that incentive is only as good as the threat of successor liability, which as we have seen may be spotty.

If the external reorganization fails to make provision for future claims, and foreseeable future claims nevertheless appear, the future claimant should be able to seek relief from the bankruptcy court against the acquirer. At the least, the court should imply the acquirer's CDA obligation to the future claimant. ${ }^{265}$ The future claimant's position as a residual owner of the business in bankruptcy entitles her to demand equal treatment with her fellow owners-that is, the other unsecured creditors who have already received their distributions through external reorganization. Depending on the equities of the case, the court might impose other remedies as well. ${ }^{266}$

On the other hand, merely imposing CDA liability after the fact may be too small a stick to assure inclusion of future claims in all cases. It provides no ex ante deterrent to ignoring future claims. A more aggressive approach might deny the acquirer the benefit of any discount in liability. In other words, a future claimant not accorded acceptable treatment in external reorganization would have the right to collect 100-cent dollars from the going concern in the acquirer's hands, purely as a matter of bankruptcy law. This remedy in fact parallels the established result in internal reorganization for a claim not afforded due process: the claim survives against the going concern. ${ }^{267}$

That approach admittedly places a premium on careful due diligence by the acquirer. However, that fact by itself should not detain us. Although prospective acquirers may wish to shy away from entanglement in the details of the bankruptcy proceeding, that position is now untenable. Courts have endorsed successor liability to protect future claimants following a bankruptcy sale that ignored their rights. Acquirers have no choice but to concern themselves with future claims in bankruptcy.

\footnotetext{
${ }^{264}$ See supra notes 130-31 and accompanying text.

${ }^{265}$ Cf. Jackson, Translating Assets and Liabilities, supra note 80, at 96 ("Existing claimants may use bankruptcy to discharge [future] tort liability at an appraisal that they (or the debtor) know to be too low; and the tort doctrine of successor liability may exist to minimize this species of misbehavior as well.").

${ }^{266}$ For example, the debtor's schedules are signed and filed under penalty of perjury. See 11 U.S.C. app. Official Bankruptcy Form 6 (1994 \& Supp. III 1997). Once it becomes clear that future claimants are creditors, debtors should be required to schedule them, at least generally, so that the court and the U.S. Trustee are on notice that future claims are an issue.

${ }^{267}$ See supra note 145.
} 


\section{CONCLUSTON: IMPERFECT SOLUTIONS}

I have described an approach to future claims in external reorganization that mandates their inclusion in the bankruptcy proceeding and the extinguishment of any successor liability rights. The fundamental point is that future claimants, as creditors of the debtor-manufacturer, must be treated as such in the manufacturer's external reorganization. Especially where a going concern survives to generate value for investors, future claimants are entitled to their equal share of that value.

Given the extant regimes of corporate and tort law, I have attempted to construct a balanced and conceptually consistent approach to treatment of future claims. It is unlikely that any structure exists to satisfy fully all the competing demands of predictability and finality, financial and economic rehabilitation, adequate and efficient compensation, and fairness. However rough and inelegant may be the accommodation described herein, it results from the conflicting aims of the various doctrines.

That goals may conflict, however, does not suggest that improvements can not be made in their accommodation. To date, accommodation of conflicting goals has largely been at the expense of future claimants. The temptation to balance competing interests on the backs of future claimants is overwhelming. They are faceless parties with only abstract future rights to assert. The costs of including them tempt us to ignore them instead. Especially outside of the large cases, cost-effective solutions may be elusive.

Although harms to future claimants are remote in time, they are real nonetheless. The costs and consequences of delayed tort liabilities can no longer be ignored. One might take issue with the tort law system as currently configured, but reform if undertaken should be done explicitly, and not through manipulation of corporate and bankruptcy rules. In the meantime, corporate and bankruptcy law ought to accord future claimants their due. I have proposed one possible approach, which clearly sacrifices some predictability and finality in favor of compensating future claims. Other approaches may appear as well. We can be sure, though, that progress will elude us until we decide to take future claims seriously. 
